NEREIDA VIANA DOURADO

À procura das miçangas para o fio do colar: uma metáfora para o ensino 
NEREIDA VIANA DOURADO

\section{À procura das miçangas para o fio do colar: uma metáfora para o ensino}

Tese apresentada ao Curso de Doutorado em Educação Faculdade de Educação da Universidade de São Paulo, para obtenção do título de Doutora em Educação.

Área de concentração: Linguagem e Educação

Orientador: Dr. Valdir Heitor Barzotto

Apoio: FAPEMA 
AUTORIZO A REPRODUÇÃO E DIVULGAÇÃO TOTAL OU PARCIAL DESTE TRABALHO, POR QUALQUER MEIO CONVENCIONAL OU ELETRÔNICO, PARA FINS DE ESTUDO E PESQUISA, DESDE QUE CITADA A FONTE.

Catalogação na Publicação

Serviço de Biblioteca e Documentação

Faculdade de Educação da Universidade de São Paulo

375.1

D739p
Dourado, Nereida Viana

A procura das miçangas para o fio do colar: uma metáfora para o ensino / Nereida Viana Dourado; orientação Valdir Heitor Barzotto. São Paulo: s. n., 2017.

130 p. ils.; tabs.; anexos

Tese (Doutorado - Programa de Pós-Graduação em Educação. Área de Concentração: Linguagem e Educação) - - Faculdade de Educação da Universidade de São Paulo.

1. Discurso 2. Linguagem 3. Educação 4. Ensino I. Barzotto, Valdir Heitor, orient. 
DOURADO, Nereida Viana. À procura das miçangas para o fio do colar: uma metáfora para o ensino. 2017. Xf. Tese (Doutorado em Educação) Faculdade de Educação da Universidade de São Paulo. 2017.

Aprovada em:

Prof. Dr.:

Instituição:

Prof. Dr.:

Instituição:

Prof. Dr.:

Instituição:

Prof. Dr.:

Instituição:

Prof. Dr.:

Instituição: 
Em memória da minha mãe e para ela: minha miçanga colorida, transmutada em pérola para um colar que (se) partiu. 


\section{AGRADECIMENTOS}

Ao meu orientador, professor Valdir, pelo convite constante ao desassossego, que é um modo singular de orientar.

Ao Grupo de Estudos e Pesquisa Produção Escrita e Psicanálise (GEPPEP), onde aprendi a olhar para as possibilidades do percurso, antes de dizer das certezas dos fins.

Aos meus professores do doutorado, que tramaram comigo esta tese, capitulo por capítulo: Dra. Cristiane Maria Corneli Gottchalk; Dr. Jorge Manuel Nunes Ramos do Ó; Dr. Valdir Heitor Barzotto; Dra. Maria de Fátima Carneiro Ribeiro Pereira; Dra. Maria Ângela Borges Salvadori; e Dra. Diana Gonçalves Vidal.

À Faculdade de Educação e seus funcionários, especialmente à secretaria da pós-graduação, pelo apoio e acolhimento, tão importantes para uma estranha em (univer)cidade grande.

Ao Instituto Federal de Educação, Ciência e Tecnologia do Maranhão, especialmente na pessoa da professora Valéria Maria Carvalho Martins, Próreitora de Gestão de Pessoas, por autorizar minha liberação para fazer o doutorado.

À Fundação de Amparo à Pesquisa do Maranhão (FAPEMA), que investiu no meu projeto e tornou possivel que eu realizasse um doutorado fora do estado.

Ao amor, à amizade e à confiança

Das minhas filhas, Maitê e Iana, shekh ma shieraki anni, yer jalan atthirari anni. O lugar onde o amor é a prática cotidiana.

Da minha irmã, Náiade, meu espelho partido que refletiu várias Luas. E me trouxe Penélope, no trem de chegada.

Da minha amiga, Sonia, que gestou, comigo, as alegrias que não couberam em mim e as dores que eu não pude suportar.

Da minha família em São Paulo, Laetícia e Isadora, meu abrigo em canto de quarto, em canto de abraço e em-canto de alma.

Dos meus amigos, Rosário, Joaquim e Macilda, na alegria de cada volta - o reencontro. 
Dos meus "manos", Augusto, Nathaly, Maristela e Ana Carolina, minha casa iluminada de alegria em São Paulo.

A Deus, pelos milagres em mim. 
Os espelhos partidos têm muito mais luas. (QUINTANA, 2006, p.74) 


\section{RESUMO}

DOURADO, Nereida Viana. À procura das miçangas para o fio do colar: uma metáfora para o ensino. 2017. Xf. Tese (Doutorado em Educação) Faculdade de Educação da Universidade de São Paulo. 2017.

Esta tese trata da compreensão do lugar do ensino na articulação entre Linguagem e Educação que está proposta em linhas de pesquisa de universidades públicas brasileiras, na medida em que (essa articulação) as nomeiam. A imagem que a orienta, um colar de miçangas, é uma metáfora criada para dar sustentação ao processo de organização dos dados a serem lidos pelo conceito de Discurso. O objetivo que gerou o itinerário deste trabalho é localizar o ensino na articulação, analisar em que medida ele promove o diálogo entre essas duas áreas e verificar se há a constituição de um novo campo de pesquisa quando esse diálogo acontece. O corpus foi constituído pelas ementas das linhas de pesquisa que trazem essa articulação em seus nomes. O que dá sustentação metodológica à tese é a Análise do Discurso (Pêcheux, 1995) e a Teoria Polifônica da Enunciação (Ducrot, 1987). A partir dos dados - as ementas de 31 linhas de pesquisa pode-se dizer que o ensino atravessa os sujeitos constituídos nos seus lugares (os lugares das áreas, uma e outra e outras, que delas se aproximam, nas ementas), como o fio atravessa as miçangas, compondo a unidade das diferenças: um não-lugar (Certeau, 2014) que sustenta e possibilita a travessia entre uma área e outra, entre o mesmo e o diferente, entre o tradicional e o novo.

Palavras-chave: Discurso. Linguagem. Educação. Ensino. 


\begin{abstract}
DOURADO, Nereida Viana. Searching the beads for the necklace's thread: a metaphor for teaching.. 2017. Xf. Tese (Doutorado em Educação) Faculdade de Educação da Universidade de São Paulo. 2017.

This thesis addresses the understanding of the place that teaching holds considering the articulation between the areas of Language and Education that is proposed in lines of research in Brazilian public universities, to the extent to which it (such articulation) names those areas. The image that guides this work, a necklace of beads, is a metaphor created to support the process of organizing the data to be understood under the construct of Discourse. The objective that generated the path of this work is to locate the teaching in the articulation, to analyze to what extent it promotes the dialogue between these two areas and to verify if the constitution of a new field of research is created when this dialogue happens. The corpus was constituted by the references of research areas that bring this articulation in their names. What gives methodological support to the thesis are Discourse Analysis (Pêcheux, 1995) and Polyphonic Theory of Enunciation (Ducrot, 1987). From the data - the references of 31 lines of research - it can be said that education goes through the constituted subjects in their places (the places of both areas, one and another and others with similitude in the references), as the Thread goes through the beads, composing the unity of differences: a non-place (Certeau, 2014) that sustains and enables the crossing from one area to another, from sameness to difference, from traditional to new.
\end{abstract}

Keywords: Discourse. Language. Education. Teaching. 


\section{LISTA DE QUADROS}

Quadro 1 - Nomes da linhas de pesquisa .30

Quadro 2 - Metonimias de Linguagem e de Educação nos nomes das linhas de pesquisa 34

Quadro 3 - As ementas e o que dizem sobre as metonimias ....................42

Quadro 4 - O aposto nos nomes das linhas de pesquisa .......................46

Quadro 5 - O aposto nas ementas das linhas de pesquisa .....................46

Quadro 6 - Temas com os quais Linguagem e Educação se articulam .......53

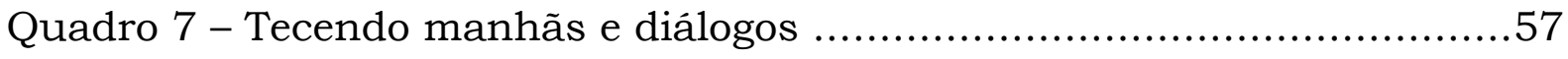

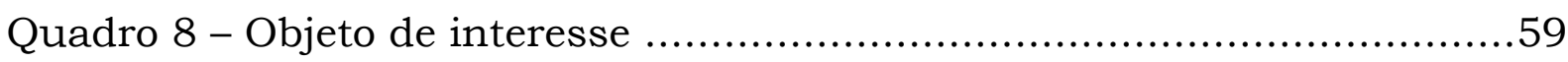

Quadro 9 - Linguagem e Educação / Educação e Linguagem: ementas ....65

Quadro 10 - A ordem do discurso ..................................................66

Quadro 11 - Esquema do processo enunciativo ...................................70

Quadro 12 - Formações imaginárias - esquema 1 ................................73

Quadro 13 - Formações imaginárias - esquema 2 .................................74

Quadro 14 - O ensino nos nomes e nas ementas das linhas de pesquisa ...77

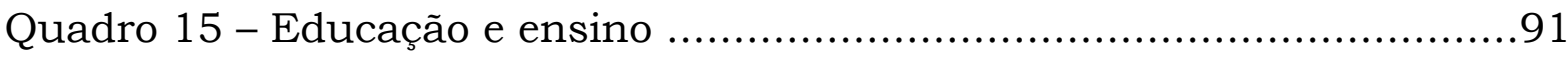

Quadro 16 - Linguagem e Educação / Educação e Linguagem ..................91

Quadro 17 - Educação e ensino / Linguagem e língua .............................99 


\section{SUMÁRIO}

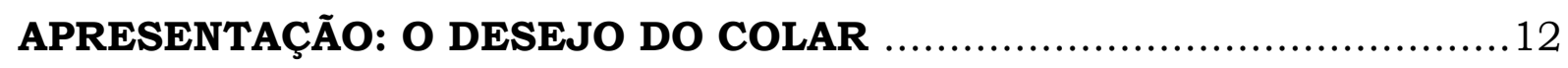

1. INTRODUÇÃO: PRIMEIROS TRANÇADOS .................................17

2. DA ROÇA PARA A ROCA: O TECIDO DO FIO NA TRAMA DO

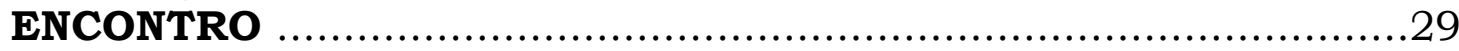

2.1. O LINHO E O FIO: O QUE NOMEIA O NOME ..................................30

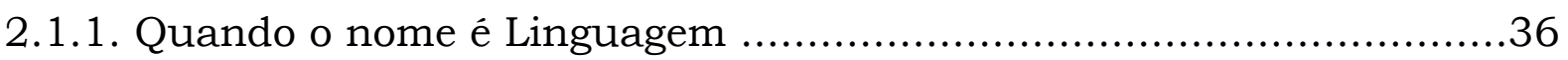

2.1.2. Quando o nome é Educação ....................................................39

2.2. O FIO E O FUSO: O LUGAR DA TRAMA ….................................42

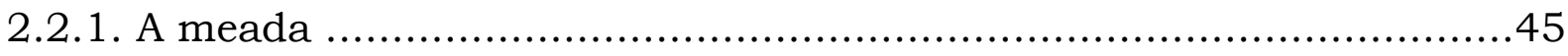

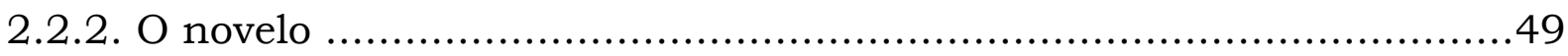

3. DA TEIA PARA O TEAR: O ENREDAMENTO DAS VOZES NA TRAMA

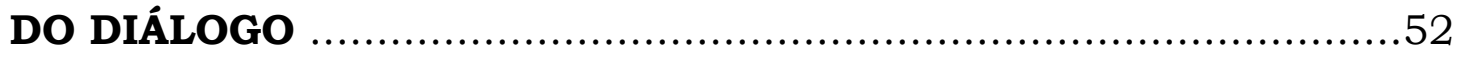

3.1. OS FIOS DE VOZES: EFEITO DA ARTICULAÇÃO DAS MIÇANGAS ...60

3.2. AS IMAGENS DAS MIÇANGAS ..................................................72

4. O FIO QUASE INVISÍVEL EM COLAR VISTOSO .......................76

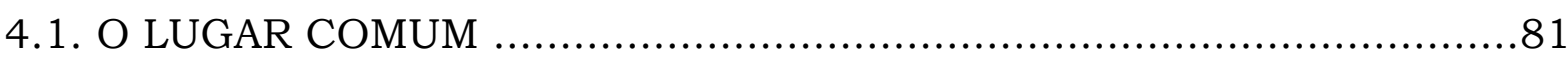

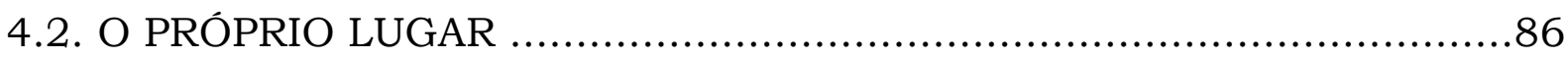

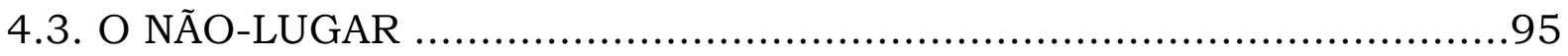

5. CONSIDERAÇÕES FINAIS: ÚLTIMOS ARREMATES …..............105

EPÍLOGO: O DESEJO E O COLAR …....................................... 114

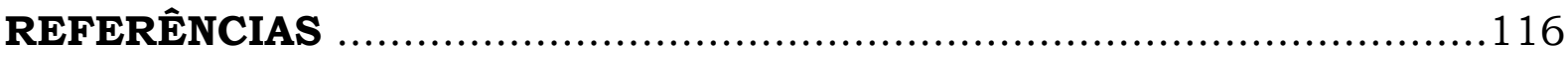

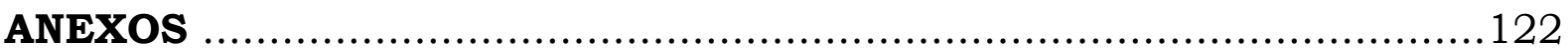




\section{APRESENTAÇÃO: O DESEJO DO COLAR}

Tomás não sabia então que as metáforas são uma coisa perigosa. Não se brinca com as metáforas. O amor pode nascer de uma simples metáfora.

(KUNDERA, 2008, p.16)

Eu lembro o dia em que consegui escrever meu nome completo, sozinha, pela primeira vez. Foi de repente. Fora da escola e distante da ficha que colocavam diante de mim, na minha carteira, com um nome que diziam ser o meu, para eu desenhar, em retas desconhecidas que se tocavam sem nenhuma intimidade, numa folha branca que me davam. Fui puxando, de um fio de memória, o traço do desenho vagamente lembrado, e aquilo foi fazendo sentido no canto do livrinho que eu folheava.

“- Olha mãe, é assim?”

“- Ah, danada, certinho! Tá escrevendo teu nome? Mas não risca o livro, risca aqui, ó.”

Aquele risco era mesmo o meu nome!, confirmei. Eu, todinha, mãe e pai, ali, no papel, em letra cursiva. E daí por diante, onde eu rabiscasse aquilo, era eu marcada naquela coisa. E assim foi: parede - eu, na parede; mesa - eu, na mesa; areia de praia - eu, grudada no chão, levada pela onda; na ponta do dedo, no ar - eu, voando. Fui lançada em uma dimensão do mundo na qual desenhos indiferentemente mudos começaram a me dizer coisas. Antes estáticos, presos opacos em lugares por onde eu costumava passar no caminho para a escola, agora me gritavam, me atravessavam e se colavam em mim, na minha cabeça pelo lado de dentro, forma e sentido, tudo de uma vez.

Foi assim que entrei, pela janela do meu nome, no mundo da escrita. 
Da escrita do meu nome, que me deu, simbolicamente, poder sobre o mundo - sobre um mundo nomeado - até aqui, sempre que posso, prefiro estar na dimensão do simbólico: da linguagem e da metáfora; da semelhança; do lugar-de. É um jeito meu de pensar e de habitar o espaço, tão definido por parecências. Daí a metáfora conceitual que orienta esta tese, tecida de fios e de miçangas em forma de colar. O título foi inspirado na epígrafe do livro de contos O fio das miçangas, do autor moçambicano Mia Couto (2009) - menos a grafia da palavra. A metáfora possibilitou que eu organizasse minha escrita e que eu estruturasse a lógica da composição do colar.

Falar de um fio transparente, escondido entre miçangas e determinado por elas era o desafio desta escrita. Para sustentar a metodologia dessa escrita, decidi por um conceito da Linguística que não afeta as categorias de análise, com base no discurso.

A metáfora é a minha pedra fundamental e foi inspiração para o título da tese, mas não só. Ela me ajudou, no processo de escrita, a visualizar um itinerário, embora o caminho fosse aparecendo no próprio caminhar. $\mathrm{Na}$ verdade, a metáfora me deu sustentação no meu processo de organização dos dados, a serem lidos pelo conceito de discurso, e me possibilitou ver os abstratos (as abstrações): tanto o ensino como os discursos que os constituem.

Para sustentá-la na cientificidade da produção acadêmica, busquei apoio na Análise do Discurso (PÊCHEUX, 1995) e no conceito de metáfora conceitual (LAKOFF; JOHNSON, 2002), que ampliaram o lugar de recurso expressivo que a metáfora ocupou, desde Aristóteles, até alcançar o de um fenômeno linguístico através do qual o conhecimento da realidade pode ser apreendido, organizado ou desvelado, no que a imagem suporta em possibilidades. Ou seja, a metáfora aparece, em ambos os casos, não só como constituinte da linguagem poética, mas também das linguagens cotidiana e científica. 
Na Análise do Discurso, a metáfora não é um desvio de um sentido primeiro, fundada nas relações de similaridade e de substituição como o é na Linguística. Embora não se perca totalmente de vista esse conceito, a metáfora constitui uma condição da linguagem, como a definiu Pêcheux (1995), uma vez que o efeito produzido por um objeto simbólico é sempre passível de ser outro.

Como não há um sentido fixado nos usos da linguagem, os efeitos metafóricos são constituintes desses usos e são determinados por valores sintáticos, mas também sociais, culturais e afetivos. Localizam-se nos lugares onde a língua (o sistema) "falha" e sua ordem se rompe. Dessa fenda irrompem a polissemia, a criatividade, o jogo, a afetividade, o inusitado e o singular, os silêncios, as imagens... e os equívocos também. São experiências de vida e de morte, de lugares e de travessias que, na construção do sujeito, desconstroem as primeiridades ${ }^{1}$ dos sentidos e marcando, os dizeres, de interferências diversas.

Os efeitos de sentido (e, neles, os metafóricos) constituem um objeto de compactação de sentidos e favorecem, também, o explicar, o compor, o organizar, o relacionar e o produzir conhecimento sobre o ensino. O fio como metáfora do ensino, é só o fio, não é colar, nem ensino. Sinto que essa metáfora me mantém no percurso que iniciei com a escrita do meu nome, mesmo que calçada em outros passos.

Por outro veio, Lakoff e Johnson (2002) parte do que ele considera ser a natureza da metáfora - a cognição. É uma faculdade que tem um potencial mediador entre o que é perceptível e o que é inteligivel, por isso defende sua presença em usos cotidianos e científicos. Esses usos resultam de seleções subjetivas, de experiências, sobretudo espaciais (geográficas), que ligam

\footnotetext{
1 O neologismo é uma alusão ao "primeiro sentido", ensinado, há algum tempo, como o sentido "verdadeiro" ou literal ou denotativo das palavras, em oposição a um sentido "figurado".
} 
domínios semânticos ${ }^{2}$ diferentes, um mais abstrato, outros mais concretos. O significado da expressão “Tudo em cima”, por exemplo, para dizer que "está tudo bem", é construído a partir de um componente físico (o espaço, "em cima”), de um cultural (a posição “em cima”, em oposição à posição “em baixo" tem aspecto positivo), de um mental (que é o conhecimento partilhado dos dois primeiros componentes, e que permite a compreensão do enunciado) e de um performativo (o uso a expressão em uma situação específica, para descrever um estado ou manter aberto o canal de comunicação, por exemplo).

A metáfora conceitual projeta uma ponte entre aquilo que tem uma natureza mais racional e concreta e aquilo que tem caráter mais emocional, em termos simbólicos (pois que são construções de linguagem), ampliando possibilidades de comunicação, na medida em que um domínio (mais concreto, físico) permite compreender melhor o outro (mais abstrato, conceitual).

Essas metáforas são mapeamentos ${ }^{3}$ entre dominios (o dominio fonte e o domínio alvo), transferidos para a própria construção sintática. Por exemplo, a comparação metafórica "tempo é dinheiro" ("tempo" é a fonte e "dinheiro" é o alvo) aciona uma série de correspondências conceituais que vão estar presentes, subliminarmente, em usos como "perder tempo", "economizar tempo", "gastar tempo", "ganhar tempo” etc. Esta é uma visão muito objetivista do uso da linguagem, mas para a construção da imagem do colar de miçangas me foi muito útil. Ajudou a "encorpar" (dar corpo) a percepção que eu tinha de Linguagem e Educação, articuladas em nomes de linhas de pesquisa.

Há algumas impressões que constituem a substância da minha metáfora: quando vejo Linguagem e Educação, reconheço-as como duas áreas de conhecimento distintas, que estão, juntas, formando outra coisa, distinta de "cada uma" - uma unidade. O que vejo primeiro é o resultado da articulação;

2 Lakof e Johnson (2002) postula uma estrutura interna para os dominios semânticos, quais sejam: dominios fisicos, dominios culturais ou sociais, dominios mentais ou centrais e dominios performativos. Na interação destes que se funda o sujeito.

${ }^{3}$ Conjunto de correspondências conceituais. 
depois, o que está articulado; por último, o que torna possivel a articulação. Linguagem e Educação. Linguagem / Educação. E o que há entre uma e outra existe, é o que compõe a unidade que formam, mas não que não dá pra saber o que é, na superfície; então, eu o suponho ou o pressinto. Tenho, então, um colar, de miçangas, que estão ali atravessadas e laçadas por algo, que deve ser um fio ou algo do tipo. É esse fio suposto que sustenta e que dá visibilidade às miçangas, apesar de não aparecer, no colar.

Em tese. 


\section{INTRODUÇÃO: PRIMEIROS TRANÇADOS}

Essa história começa ao rés do chão, com passos.

(CERTEAU, 2014, p.163)

As miçangas foram feitas para serem atravessadas por um fio, antes de tudo. A gente sente a falta e antevê a forma do que precisa; deseja o colar; resolve o fio e as miçangas; pensa o tamanho do fio e a cor das miçangas; começa a tecer, no fio, pedra por pedra; junta, separa, amarra. Desata - não deu certo - começa de novo.

Mas eu não estou aqui na condição de artesã. A minha posição é a de quem aprecia o trabalho de quem teceu a forma que me serve; que diz de mim, da minha falta e do meu desejo; do meu lugar de professora, com graduação em Letras e pós em Educação. É também a posição da curiosa que analisa o trabalho, para conhecer dele, para além da forma, os percursos que determinaram que ele fosse assim, e não outro - o fio, as miçangas e os nós, primeiro. E daí por diante. É a posição da pesquisadora, com graduação em Letras e pós em Educação.

Notei miçangas onde havia um colar. Sobretudo, duas, essenciais: Linguagem e Educação. O fio foi uma suposição, primeiro; supus que houvesse algum, entre elas; algo que as unia na forma que se dava a ver. E nós. Há sempre que se amarrar as miçangas para que elas deem a forma do que se quer compor.

Havia outros colares, outras composições com miçangas parecidas, certamente também trançadas em fios e nós: língua, linguagens, linguística, língua portuguesa, literatura; conhecimento, ensino, ensino-aprendizagem, tecnologias, formação do professor, formação do leitor, metodologias, 
abordagens pedagógicas... Algumas miçangas inusitadas, como utopia e práticas sociais, compunham também os colares que colecionei, primeiro.

Vasta foi a primeira exposição a que acessei; também sortida foi a minha primeira coleção, feita do desejo de saber o que se articulava na articulação entre Linguagem e Educação. Pensei primeiro em tons ${ }^{4}$, que busquei, nesse primeiro mo(vi)mento, nas publicações que apareciam de forma recorrente como referências nas monografias de conclusão da licenciatura em Letras, na Universidade Federal do Maranhão. Encontrei 13 obras, em 37 monografias. Busquei, nas prateleiras, outros títulos que propusessem essa associação. Achei bastante. E resolvi ver se havia tantos pesquisadores interessados nesse assunto quantos futuros professores de lingua portuguesa. Nesse momento achei que "pesquisadores" equivaliam a "autores" de obras que eram publicadas no mercado editorial. Encontrei, há 3 anos, 14 obras, em apenas uma editora (das 105 que consegui catalogar), que associavam, em seus títulos, essas duas áreas. Era muita coisa. E olha que esse número dizia apenas das publicações em que Linguagem e Educação apareciam de forma bastante clara, e nos nomes das obras. A quantidade me dizia que era um assunto de grande interesse para a comunidade acadêmica e eu queria, à época, apurar a audição para ouvir o que a voz da (área da) Linguagem dizia para a Educação e o que a voz (da área da) Educação dizia para a Linguagem; em que nível de hierarquia - caso houvesse uma - a Linguagem e a Educação dialogavam - se dialogassem; em que nivel a especificidade afetava a generalidade e/ou o seu contrário.

A gente vai perdendo a inocência, na pesquisa, isso é um fato.

Lendo aqui, conversando acolá, aprendi algumas coisas sobre mercado editorial - mercado, primeiro; sobre pesquisadores e sobre autores. O mercado editorial, concluí, tem um critério, às vezes, muito particular, para a escolha

${ }^{4} \mathrm{O}$ projeto de pesquisa com que fui aceita no Programa de Pós em Educação, na USP, foi intitulado Movimento de vozes: ensino, linguística e autoria na formação de professores de lingua portuguesa. 
dos títulos para publicação e dos títulos das publicações. Em um terceiro movimento, ainda nesse comecinho, pensei em buscar, nas Universidades, o que havia como proposta de estudo, no campo dessa articulação. Comecei acessando o portal do CNPQ, entrei na página nomeada Grupos de Pesquisa ${ }^{5}$ e, usando como palavras-chave "linguagem e educação", encontrei 178 títulos; e usando como palavras-chave "linguagem e ensino", 159 títulos. Digo "títulos" porque verifiquei que estão, nesses números, inventariados, indistintamente, o que conhecemos por grupos de estudo e por linhas de pesquisa.

Parece que o CNPQ não reconhece, oficialmente, a título de categorização, a nomenclatura grupo de estudo, e sim grupo de pesquisa e linha de pesquisa. No próprio portal, encontrei uma distinção do que seria, para o CNPQ, um Grupo de Pesquisa e uma Linha de Pesquisa: a linha de pesquisa "representa temas aglutinadores de estudos científicos que se fundamentam em tradição investigativa, de onde se originam projetos cujos resultados guardam afinidades entre si.6"; já o grupo de pesquisa é definido como "um conjunto de individuos organizados hierarquicamente em torno de uma ou, eventualmente, duas lideranças."7 Essa liderança, explica o verbete, deve ter experiência e destaque no campo das ciências ou das tecnologias; deve estar permanentemente envolvido em atividades de pesquisa, subordinar (grifo meu) uma linha de pesquisa e compartilhar instalações e equipamentos. Então, para o CNPQ, as linhas de pesquisas devem estar subordinadas aos grupos de pesquisa, e não o contrário.

No entanto, o que se vê nas Universidades é exatamente esse contrário: as linhas de pesquisa é que acabam sendo o lugar onde os grupos de pesquisa (ou de estudos) vão se fomentando.

\footnotetext{
${ }^{5}$ Disponivel em http://dgp.cnpq.br/buscagrupo

${ }^{6}$ Disponivel em http://lattes.cnpq.br/web/dgp

7 Id.Ibdem
} 
O desenho do corpus passou a ser constituído, então, pelas ementas das linhas de pesquisa de cursos de pós-graduação que propunham a articulação entre Linguagem e Educação e/ou suas metonimias, em seus nomes.

Do primeiro total de 337, tendo descartado as linhas de pesquisa e grupos de estudo de instituições particulares (por exemplo, o grupo de pesquisa Estudos de Linguagem para o Ensino de Português, da Pontifícia Universidade Católica de São Paulo); as que, embora tenham aparecido no resultado da busca, nada tinham a ver com as palavras-chave usadas como filtro (por exemplo, o grupo de pesquisa Nutrição e Produção no Semiárido, vinculado à área de Zootecnia, no Instituto Federal de Sertão-PE); aquelas que, além de Linguagem e Educação, articulavam mais de uma outra área, subárea ou especialidade $^{8}$ do conhecimento (por exemplo, o grupo de pesquisa Diversidade Cultural, Linguagem, Mídia e Educação, da USP); e as que pertencessem a outra grande área (por exemplo, o grupo de pesquisa História, Educação e Linguagem na Região Amazônica, da Universidade Federal do Pará, da área de História), encontrei 31 linhas de pesquisas, sediadas em instituições de ensino superior públicas, em todo o território nacional (Anexo I), que passou a ser o corpus da minha pesquisa - minha primeira coleção de colares. Era uma bela coleção, eram diversas as miçangas que compunham os desenhos dos colares.

O que teria aproximado essas duas miçangas?

A aproximação entre Linguagem e Educação tem sua gênese na criação dos cursos de Licenciatura em Letras. O primeiro, na Faculdade de Filosofia,

\footnotetext{
8 A CAPES (Coordenação de Aperfeiçoamento de Pessoal de Nível Superior) identifica quatro níveis na hierarquização das Áreas de Conhecimento, indo do mais geral aos mais específicos: Grande Área (classificação sob o critério da afinidade de objetos, métodos cognitivos e recursos instrumentais), Área (conhecimentos inter-relacionados com finalidades de ensino, pesquisa e aplicações práticas), Subárea (segmentação a partir da função do objeto de estudo e de procedimentos metodológicos) e Especialidade (caracterização temática da atividade de pesquisa $\quad \mathrm{e} \quad$ ensino). Disponivel em http://capes.gov.br/images/stories/download/avaliacaao/TabelaAreasConhecimento
} 
Ciências e Letras, da Universidade de São Paulo ${ }^{9}$, foi criado em 1934, para incrementar a pesquisa e a formação de professores, deslocando de Coimbra a formação de uma elite profissional. (FIORIN, 2006). No entanto, os trabalhos considerados práticos continuariam sob a responsabilidade das escolas profissionais, e as disciplinas para formar professores, dos institutos de educação (Idem). De um lado, a pesquisa; de outro, o ensino. Considerando que a Faculdade foi criada para criar uma elite profissional que deslocasse de Coimbra a formação superior, no Brasil, acredito que foi forjada, nesse tempo mesmo, na universidade, ironicamente, não só a cisão (camuflada em integração), como a hierarquia entre a pesquisa e o ensino; entre o conhecimento e a prática - entre a Linguagem e a Educação, embora as ciências devessem alimentar as práticas, sublimando-as, gradualmente.

Outro fato que identifico como tendo aproximado as minhas duas miçangas primordiais foi a obrigatoriedade da cadeira de Linguística, estabelecida no desenho curricular dos cursos de Letras, através do Parecer $\mathrm{n}^{\circ}$ 283/62, do Conselho Federal de Educação (CASTILHO, p.1, 1965), nos idos dos anos 70. Ganhou força com o retorno, para as Universidades, de mestres e doutores que haviam ido se especializar no exterior, dado que, no momento da implantação da disciplina, não havia docentes suficientes para atender a demanda dos 83 cursos de Letras que já existiam à época. Surgia aí, então, a necessidade do ensino da Linguística. Nesse momento, é criado também, na Universidade de Brasília (UnB), o primeiro Mestrado em Linguística, no Brasil (em 1964, na verdade).

A partir desse marco (a configuração da Linguística como disciplina obrigatória nos cursos de Licenciatura em Letras, que é, a princípio, um curso de formação para a docência), configurou-se crescente o entusiasmo em torno da tese de que essa disciplina renovaria o ensino da língua materna, e o

\footnotetext{
${ }^{9}$ Criado através do Decreto 6.283 de 25 de janeiro de 1934.
} 
número de publicações sobre a temática10 é um reflexo desse entusiasmo amadurecido.

Outro marco que passo a considerar como constituinte da necessidade da harmonização das miçangas em colar é a reviravolta linguística (OLIVEIRA, 2001), caracterizada pela passagem da linguagem de objeto a fundamento da reflexão filosófica. A Educação (a filosofia da educação e a história da educação, sobretudo) passa a olhar para a Linguagem para além da sua instrumentalidade e, portanto, para além das metodologias do ensino; e o objeto de ensino se expande para além da língua, como a definiu Saussure sistema de signos, de natureza simbólica, social e coletiva -, alcançando o discurso, no sentido que lhe atribuiu a Análise do Discurso Francesa - uma produção, tanto como um ato, uma criação, uma elaboração entre sujeitos, quanto como algo mais espetaculoso, quase teatral, de ser aquilo que se tem como resultado de uma projeção - um acontecimento que envolve o ator, a plateia, o teatro, o horário... E que, embora sendo resultado, não é um objeto fechado ou acabado: "aquilo pelo que se luta" (FOUCAULT, 1997, p.10).

Esse trajeto atravessa, impulsionado pelas Investigações Filosóficas, de Wittgenstein (1999), a filosofia da linguagem ideal rumo a uma filosofia da linguagem ordinária; nesta última, a ideia do jogo. A terapia filosófica proposta por ele convida a desconstruir dogmatismos e prescrições nos modos como os conceitos se constituem. No ambiente da Educação, essa terapia pode ajudar a desconstruir, por exemplo, o que se repete, sem reflexão, sobre ensino e aprendizagem; sobre a relação entre professor e aluno; sobre avaliação escolar;

\footnotetext{
10 No catálogo das duas editoras mais citadas nas referências bibliográficas das monografias de conclusão do curso de Letras defendidas nos últimos três anos na Universidade Federal do Maranhão, há 46 (14 e 32) obras, sob a rubrica formação de professores, em cujos títulos essa temática está explícita, a saber, aqueles em que palavras como ensino, educação, escola, prática e aula de português, língua portuguesa, linguagem, linguística, gramática, leitura, escrita aparecem juntas.
} 
sobre métodos de ensino etc., na medida em que relativiza as interpretações, como nos jogos de linguagem ${ }^{11}$ e nas formas de vida ${ }^{12}$.

Esse ponto da minha ponderação se desenhou em torno dos usos comuns de Linguagem e Educação, em seus ambientes de origem (a área de Letras e Educação) e do fato de que esses usos podem levar ou à repetição de um único sentido, que acaba por limitar a Linguagem a instrumento de comunicação, e Educação a técnicas de adquirir ou melhorar a habilidade de melhorar o uso desse instrumento, ou a uma profunda generalização desses conceitos. Essa observação motivou outra, que foi investigar se sentença que dispõe a "soma" Linguagem e Educação acarreta algum resultado. A terapia dessa conjunção, nos moldes wittgensteinianos, foi um exercício contra o dogmatismo que parece sempre ter o mesmo resultado, qual seja, "ensino de lingua", materna ou estrangeira.

Deslocado do ambiente de soma para o tabuleiro da linguagem, o par Linguagem/Educação, tomado como peças de um jogo, tem seu uso mediado por regras da gramática ${ }^{13}$, determinando sua função, que não está a priori: como a Linguagem joga com a Educação. Como a definição de jogos de linguagem, para Wittgenstein, envolve, além de regras, lugar e jogadores, os conceitos são relações que vão sendo geradas no interior de práticas linguísticas, cujo campo de ação é orientado por regras e não determinado por

11 Para Wittgenstein (1999), a linguagem é, ela mesma, jogos de linguagem, no sentido de que as regras de uso são instituídas e institucionalizadas pelos jogadores (falantes) e indissociáveis do ambiente (sociocultural) no qual se tramam: “o termo 'jogo de linguagem' deve aqui salientar que o falar da linguagem é uma parte de uma atividade ou de uma forma de vida." (p.35)

12 As formas de vida referem-se àquilo que é dado e aceito, que constituem uma comunidade; o ambiente no interior do qual as regras da linguagem se constituem; visto no seu viés, isso significa que as regras de linguagem utilizadas por falantes são a expressão mesma desse ambiente. Para Wittgenstein (1999, p.32), "representar uma linguagem significa representar-se uma forma de vida.". E ainda: "Correto e falso é o que os homens dizem; e na linguagem os homens estão de acordo. Não é um acordo sobre opiniões, mas sobre o modo de vida." (p.241)

13 Para Wittgenstein, a gramática e suas regras (se) organizam (a partir d)os usos práticos que os falantes fazem de uma expressão, e não o seu contrário. O desconhecimento dessas regras foi o que gerou os equivocos de interpretação dos significados que vitimou a filosofia tradicional: "A essência está expressa na gramática." (p.120). Para ele, então, não há sentidos ocultos os quais buscar na metafisica, por exemplo; o que há é o desconhecimento das regras de uso das expressões. 
elas. Essas práticas linguísticas foram as 31 ementas que selecionei. Analisados assim, o jogo entre Linguagem e Educação é uma forma de vida na qual o adestramento e o contexto vão preparando os conceitos, resultados do complexo processo do uso dessas palavras.

Considerando os nomes das linhas de pesquisa, essa conjunção resulta num paradigma, como regras convencionadas dentro de um jogo de linguagem e em diferentes jogos de linguagem. A diversidade de suas aplicações implicará no "domínio das regras", ou seja, na compreensão de seus múltiplos significados, guiando à verificação do conhecimento produzido no interior dos programas - a confecção do colar.

Vi que, nos 31 colares de que minha primeira coleção era composta, havia miçangas que se repetiam, adornando as principais e, às vezes pondo em destaque uma mais que outra, na forma como se combinavam. Havia as que destoavam, perdidas, por assim dizer, em um colar a que não pertenciam. Às vezes, também, com a principal, formavam um ton sur ton, esticando, por toda a extensão do colar, as mesmas duas. Para olhar para essa organização, para o que se repetia e para o que aparecia de inusitado, usei o método de Dedução Frequencial (PECHEUX, 2010), primeiro, para chegar a um Esquema Informacional (Ibidem) das condições de produção das ementas.

Percebi que havia algo que aparecia em quase todos os colares, mas ainda não sei se posso chamar de miçanga: o ensino. Daí a pergunta de pesquisa:

- Qual o lugar do ensino e que posição ele ocupa quando se fala em Linguagem e Educação?

Tradicionalmente, a definição de ensino está ligada a transmissão, desde sua forma de relato - transmissão da cultura oral. E na articulação Linguagem/Educação, em que está tão presente, esse lugar foi afetado, de 
alguma forma14? Se não, se o lugar do ensino continua a ser o de transmissão, o que é transmitido, na articulação? Se sim, a articulação tem delineado um novo lugar para ele, em nova posição?

Parto da hipótese de que, nessa articulação, o ensino atravessa os sujeitos constituídos nos seus lugares (os lugares das áreas, uma e outra), como o fio atravessa as miçangas, expondo a instabilidade das pedras que revestem sua transparência - quase invisibilidade. Transparente e quase invisivel, esse fio, o ensino, vai compondo a unidade das diferenças: um nãolugar que sustenta e possibilita a travessia (entre uma área e outra, talvez; entre o mesmo e o diferente, espero; entre o tradicional e o novo, desejo). Em outras palavras, as hipóteses levantadas são as seguintes:

a) Não se fala de forma diferenciada do ensino nem do lugar da linguagem e educação; nem do lugar da educação e linguagem, mas do lugar da educação ou linguagem, da linguagem ou educação;

b) Linguagem e Educação não constituem um lugar, mas dois, talvez excludentes, mesmo na articulação proposta pelas linhas de pesquisa.

O objetivo geral é compreender o lugar do ensino na articulação proposta pelos nomes das ementas das linhas de pesquisa, na pós-graduação; e os específicos são:

a) Formalizar o estado da arte no qual se procura a relação entre Linguagem e Educação proposta pelas ementas;

b) Analisar as vozes acionadas e as silenciadas na articulação;

14 De acordo com o site http://conteudoweb.capes.gov.br/conteudoweb/ProjetoRelacaoCursosServlet?acao=pesquisarA reaAvaliacao , em 1970 foi criada a Linha de Pesquisa "Lingua(gem) em contexto de ensino de português - lingua materna", na Universidade Federal do Rio de Janeiro; nos anos seguintes, a Universidade de São Paulo e a Universidade Federal de Minas Gerais, criam, em 1971 e em 1972, as Linhas de Pesquisa "Linguagem e Educação" e "Educação e Linguagem", respectivamente. 
c) Definir o que seja Linguagem e Educação, articuladas em nome de linhas de pesquisa;

d) Explorar o papel do ensino na travessia entre as áreas.

Transformadas em objetos discursivos, passo a olhar para os colares da minha coleção buscando regularidades (INDURSKY, 2007), frequências e deslizes (PÊCHEUX, 2010); paráfrases e polissemias; o mesmo e o diferente, pela referência a formações discursivas, na análise da materialidade linguística. Tomo-os (as regularidades, as frequências e os deslizes) como pistas para compreender o modo como as vozes discursivas se textualizam, através dos vestigios que deixam de si, na teia discursiva: que sujeito, como e em que circunstância fala, em função das formações imaginárias e em suas relações de sentidos e de forças.

No movimento dos processos discursivos, busco analisar os modos pelos quais o texto significa, tentando contemplar tanto o que é dito como o que não é: os silenciamentos que marcam o interdiscurso, a ideologia e as próprias formações discursivas. Esse movimento implica um ir e vir constante entre teoria, consulta ao corpus e análise. É um movimento de escuta, entre o que fala e o que silencia, nas posições discursivas que ocupam, materializando a historicidade das miçangas, para nova textualização - a tese, um novo colar. O meu colar.

Há um ruído no que parece ser o silêncio das miçangas. É preciso escutá-lo. E o fato de se tratar de escuta implica em uma leitura que perscruta a história, num tempo em que se sedimentava a expectativa de uma ciência da linguagem que, de certa forma, talvez por equívoco, tenha sido interpretada como solução para as relações linguísticas afetadas pelo conhecimento produzido. Essa ciência nova gerou expectativas, nesse sentido, para o ensino que, por sua vez, interferiria diretamente como um veiculador dessas soluções. 
É na direção dessa escuta que envolve ler sinais das interferências (GINZBURG, 1989) das condições de produção em que esses dados foram produzidos. Primeiro, procurando levantar as prioridades de leitura que estarão baseadas na articulação entre Linguagem e Educação; depois, vendo o que há de marcante nesses textos, nos imprevistos da procura, no processo de pesquisa.

É certo que há algo que une, em nomes de linhas de pesquisa, Linguagem e Educação - um fio, arrisco dizer. E um fio não é algo assim, que se dê. Como as miçangas e o próprio colar, ele é também produto, resultado de um processo, de um fiar. Antes do fio há a fibra - a ciência, cujo fazer consiste num movimento contínuo de trançar e destrançar metáforas. É onde me junto à Penélope e Gloxínia15: há um trabalho de tecer e destecer, de fiar e desfiar no fazer científico, no trabalho de pesquisa e na sua escrita. Vejo as miçangas na trama do colar; desfio colares prontos para ver as miçangas e entender como foram entrelaçadas; e tranço, também, miçangas, para um novo colar, que não é nenhum dos que tinha, em coleção, mas outro, que mostra dessa coleção as mesmas miçangas, mas com outro desenho e para outro uso - a minha tese. $\mathrm{O}$ meu colar foi tramado assim: um primeiro capitulo, Da roca para a roça: o tecido do fio na trama do encontro, cujo objetivo é formalizar o que há sobre Linguagem e Educação, a partir das informações disponibilizadas pelo MEC e pelas universidades públicas que têm linhas de pesquisa com esse nome. É onde começa a busca pelo que as articula - o fio, que acredito haver. No segundo capítulo, Da teia para o tear: o enredamento das vozes na trama do diálogo, analiso a articulação entre minhas miçangas, com o objetivo de ouvir,

15 Penélope é uma personagem da mitologia grega que aparece na Odisseia (Séc. VIII a.C. Tradução de Manoel Odorico Mendes, 2009) que, aconselhada pelo rei seu pai a escolher um novo marido, tendo em vista que o seu, Ulisses (ou Odisseu) partira para a guerra (de Tróia) há muito, sem que se soubesse dele o paradeiro, impõe, como tempo e condição para escolher novo marido, a finalização de um manto por suas mãos tecido. Como artifício para adiar a decisão, a princesa de Ítaca destece, pela noite, o que havia tecido durante o dia. Já Gloxinia, na mesma esteira, é uma personagem do conto Fio após fio, de Marina Colasanti (2006), que combina, com a irmã, Nemésia, que aquela das duas que bordasse o mais belo desenho no manto em que trabalham juntas, teria direito de usá-lo. Perfeccionista, a fada desborda durante a noite os desenhos que, com capricho, bordara durante o dia, para começar tudo novamente. 
no farfalhar das miçangas decompostas, as vozes que tramam um diálogo ou que destoam, em desalinho, mesmo trançadas em colar. O terceiro capítulo, O fio quase invisivel em colar vistoso, é sobre o que alinha a Linguagem e a Educação (o fio suposto e os nós necessários) em um colar, mas que nem sempre aparece, nem sempre está visivel, nem sempre é, necessariamente estável, forte ou adequado, embora seja imprescindivel na trama das miçangas para o colar. 


\section{DA ROÇA PARA A ROCA: O TECIDO DO FIO NA TRAMA DO ENCONTROINTRO}

Onde será que isso começa

A correnteza sem paragem

$\mathrm{O}$ viajar de uma viagem

A outra viagem que não cessa

Cheguei ao nome da cidade

Não a cidade mesma, espessa

Rio que não é rio: imagens

Essa cidade me atravessa

Será que tudo me interessa?

Cada coisa é demais e tantas

Quais eram minhas esperanças?

O que é ameaça e o que é promessa? [...]

A gente chega sem chegar

Não há meada, é só o fio

(VELOSO, 1992)

Há uma grandeza contida no linho, que data de tempos remotos. Na Bíblia Sagrada dos cristãos, a destruição de uma plantação de linho é uma das Sete Pragas do Egito (Êxodo, capítulo 9, versículo 31), e é de linho o tecido das vestes de Jesus, na promessa de sua volta (Apocalipse, capítulo19, versículo 8). Sua semente, a linhaça, é veículo na preparação de tintas e, na culinária, dá "liga"a ingredientes na preparação de receitas. Se há um fio que atravessa as miçangas, ligando-as, em colar, pela sua simbologia, processo, historicidade, importância e singeleza, esse fio há de ser de linho - aqui.

O linho começa a ser fibra depois da colheita, pelo processo de ripagem. O caminho que faz do linho fibra e da fibra fio é longo, uma viagem. Isso começou antes, na busca pelos lugares onde eu poderia encontrar o fio das miçangas, ainda na sua forma de fibra - as páginas oficiais sobre a educação, no Brasil e as das universidades públicas. Ao chegar aos programas de pósgraduação (Educação e Letras), não há meada, é só fio e, ainda assim, não dá pra vê-lo, senão pela trama das miçangas, no nomear das linhas de pesquisa. 
Mas dizer o nome não é dizer do trabalho, assim como chegar ao nome da cidade não é chegar a cidade mesma, espessa, a que atravessa: imagens; o Rio que não é rio. Ainda assim, o nome próprio "torna-se um espaço do jogo" (CERTEAU, 2013, p.233), em volta do qual "se produz [...] uma constelação de adjetivos ou predicados" (p.232), criando um espaço complexo. Cada um desses predicados "se torna metonimia do nome próprio" (p.232), ou seja, têm, com ele, uma relação de contiguidade. É pensando assim que tomo alguns substantivos que se conjuminam aos nomes Linguagem e Educação ou os substituem, nos mesmos lugares de interlocução, como metonímias das próprias miçangas originais. Embora eu veja, nas substituições e nas adjunções uma relação metonímica, não posso dizer que o efeito de sentido seja o mesmo. Passo a buscar, nas semelhanças, as diferenças.

\subsection{O LINHO E O FIO: O QUE NOMEIA O NOME}

Olhando dessa forma, os nomes (próprios) das linhas de pesquisa foram o filtro que me ajudou a (es)colher os colares, por suas miçangas. Pelo filtro passaram os colares com as miçangas que eu buscava e com outras, não iguais, mas contíguas. Essa contiguidade foi percebida pela relação semântica e pela posição na articulação: metonimias, que "fazem passar de um equivalente a outro da mesma identidade" (CERTEAU, p.233). Sempre há algo que escapa na plasticidade necessária a um filtro de colares de miçangas. O que atravessou o filtro ficou, e vai aparecer no primeiro quadro, que segue abaixo:

Quadro 1: Nomes das linhas de pesquisa
\begin{tabular}{|c|l|}
\hline \multicolumn{2}{|c|}{ PROGRAMA: EDUCAÇÃO } \\
\hline E1 & Educação e linguagem \\
\hline E2 & Educação e linguagens \\
\hline E3 & Educação e linguagem \\
\hline
\end{tabular}




\begin{tabular}{|c|c|}
\hline E4 & Linguagens, diversidade cultural e inovações pedagógicas \\
\hline E5 & Linguagem, conhecimento e formação de professores \\
\hline E6 & Linguagem, literatura, educação e sociedade \\
\hline E7 & Culturas escolares e linguagens \\
\hline E8 & $\begin{array}{l}\text { Linguagens, cultura e construção do conhecimento: } \\
\text { perspectivas histórica e contemporânea }\end{array}$ \\
\hline E9 & Educação e linguagem \\
\hline E10 & $\begin{array}{l}\text { Linguagem: processos de produção de linguagens, } \\
\text { identidades culturais e práticas educativas }\end{array}$ \\
\hline E11 & Práticas educativas, linguagens e tecnologia \\
\hline E12 & Educação, linguagem e formação do leitor \\
\hline E13 & Cultura escrita, linguagens e aprendizagem \\
\hline E14 & Culturas, linguagens e utopias \\
\hline E15 & Educação e comunicação \\
\hline E16 & Educação, comunicação e tecnologia \\
\hline E17 & Linguagem e educação \\
\hline E18 & Linguagem e educação \\
\hline E19 & Abordagens pedagógicas do ensino de linguagem \\
\hline \multicolumn{2}{|r|}{ PROGRAMA: LETRAS } \\
\hline E20 & $\begin{array}{l}\text { Linguística aplicada: ensino e aprendizagem de língua } \\
\text { materna e estrangeira }\end{array}$ \\
\hline E21 & Ensino de linguagens \\
\hline E22 & Análise de práticas de linguagem no campo do ensino \\
\hline E23 & Ensino-aprendizagem de línguas \\
\hline E24 & $\begin{array}{l}\text { Ensino da língua portuguesa: história, politicas, sentido } \\
\text { social, metodologias e pesquisa }\end{array}$ \\
\hline
\end{tabular}




\begin{tabular}{|c|l|}
\hline E25 & Ensino e aprendizagem de línguas \\
\hline E26 & Ensino de linguas e literaturas \\
\hline E27 & Língua e interação em contexto de ensino \\
\hline E28 & $\begin{array}{l}\text { Língua(gem) em contexto de ensino de português - língua } \\
\text { materna }\end{array}$ \\
\hline E29 & Língua e ensino \\
\hline E30 & Linguagem, tecnologia e ensino \\
\hline E31 & Linguagem e ensino \\
\hline
\end{tabular}

Como que em um processo de assedagem, busquei separar as fibras, primeiro no que vi de semelhante, depois nas diferenças que foram se mostrando. As posições, por exemplo, que ocupam nos nomes das linhas de pesquisa (Linguagem e Educação ou Educação e Linguagem e suas metonímias) me pareceu, a princípio, uma dissemelhança que pudesse mostrar, depois, uma regularidade constituinte de sentido.

Mas não. Essa ordem não privilegiou o pertencimento a uma ou a outra área. Talvez seja o rastro de um vínculo com uma linha, criada anterior a ela, de onde o seu coordenador ou organizador possa ter vindo ou pela qual tenha sido afetado, de alguma forma. Pode ser que a posição dos nomes se repete ou se inverte ou se camufla em metonímias como marca da interferência de outra linha de pesquisa, seja pela ratificação (da necessidade), pela negação (de uma certa necessidade) ou pela retificação (correção da necessidade).

O Brasil tem 27 unidades federativas (26 estados e um Distrito Federal); distribuídas nesse universo, 113 universidade públicas, nas quais há 462 cursos de (licenciatura em) Pedagogia e 657 de (licenciatura em) Letras ${ }^{16}$. Ao

16 Informações disponiveis em http://emec.mec.gov.br/ 
lado desses números, outros ${ }^{17}$ mostram, no entanto, que há algo de que essa formação não está dando conta, que há algo, nelas, carecendo de um cuidado maior, de uma atenção mais acurada.

Estou usando esses números para destacar o reconhecimento da relevância da pesquisa em Linguagem e Educação, o que significa a constituição de um campo de pesquisa vasto e pode significar a instituição de uma área: das 70 instituições que têm pós-graduação nas áreas de Letras e de Educação, 31 têm linhas de pesquisa que investigam temas de interesse dessa articulação. Esses quase 45\% são índices de uma necessidade.

$\mathrm{O}$ conceito de necessidade tange o conceito de exigência, em um certo sentido. Na filosofia clássica, necessidade diz respeito às formas possiveis de relação do ser humano com seus semelhantes e com as coisas, no geral, e, portanto, com "leis", com formas de regulamentação, pois que se constrói em virtude de uma causa externa, que é, por si própria, a causa da necessidade: “aquilo que não pode ser de outra forma” (ABAGGNANO, 2000, p.704). Leibniz (1646-1716) abre um espaço de liberdade de escolha dentro da tradição aristotélica, quando acrescenta, às necessidades física e geométrica, a necessidade moral, que ele define como "a escolha do sábio por ser digna de sua sabedoria, ou seja, a escolha do melhor".

Trazendo para o ambiente mais específico da educação, o conceito de necessidade assume significado muito próximo ao filosófico: as "lacunas" ou "deficiências" que são percebidas dentro de um conjunto de normas. Seus usos são diversos, e podem-se referir desde à ausência de um professor, até um conteúdo a ser contemplado na elaboração do desenho curricular, passando pela prescrição de medidas corretivas. A necessidade é o resultado de uma

17 Apenas 12 licenciaturas em Pedagogia e 41 em Letras possuem o conceito máximo do ENADE; e, nas 113 universidades públicas brasileiras, há 70 cursos incentivando a pesquisa sobre formação de professores, em programas de Mestrado e Doutorado. São 35 cursos de pós em Educação e 35 em Letras, sendo que 20 dessas instituições oferecem pós nas duas áreas. Disponivel em https://sucupira.capes.gov.br/sucupira/ 
falta. A articulação entre Linguagem e Educação marca, então, a falta, a necessidade e o desejo - o diálogo, em forma de promessa e de fio a ser tecido para um colar.

Há 6 linhas de pesquisa em que essa promessa está mais nítida, em imagem: as que são nomeadas exatamente Linguagem e Educação / Educação e Linguagem. Elas estão vinculadas a programas de pós-graduação em Educação, sem, pois, a marca da área na posição em epiteto. Sem esse liame, passo a observar, de uma forma mais geral, como se configuram os nomes das linhas de pesquisa. Vou tratar especificamente delas mais adiante.

Como o lugar é algo que me interessa bastante e é determinante na produção do discurso, começo pelo que ocupa, nas linhas, as posições que seriam de Linguagem e de Educação (Quadro 2). Essa substituição pode iluminar algo do que seja a concepção de Linguagem e de Educação.

Quadro 2: Metonimias de Linguagem e de Educação nos nomes das linhas de pesquisa

\begin{tabular}{|c|l|l|}
\hline & (na posição de) Linguagem & (na posição de) Educação \\
\hline E2 & LINGUAGENS & \\
\hline E4 & LINGUAGENS & INOVAÇÕES PEDAGÓGICAS \\
\hline E5 & \multicolumn{1}{|c|}{ FORMAÇÃO DE PROFESSORES } \\
\hline E7 & LINGUAGENS & CULTURAS ESCOLARES \\
\hline E8 & LINGUAGENS & $\begin{array}{l}\text { CONSTRUÇÃO DO } \\
\text { CONHECIMENTO }\end{array}$ \\
\hline $\begin{array}{c}\text { E1 } \\
0\end{array}$ & & PRÁTICAS EDUCATIVAS \\
\hline E1 & LINGUAGENS & PRÁTICAS EDUCATIVAS \\
\hline 1 & & APRENDIZAGEM \\
\hline E1 & LINGUAGENS & UTOPIAS \\
\hline E1 & LINGUAGENS & \\
\hline
\end{tabular}




\begin{tabular}{|c|l|l|}
\hline 4 & & \\
\hline E1 & COMUNICAÇÃO & \\
\hline E1 & COMUNICAÇÃO & \\
6 & & \\
\hline E1 & - & ABORDAGENS PEDAGÓGICAS DO \\
9 & & ENSINO \\
\hline E2 & LINGUÍSTICA APLICADA & ENSINO E APRENDIZAGEM \\
0 & & \\
\hline E2 & LINGUAGENS & ENSINO \\
1 & & \\
\hline E2 & PRÁTICAS DE LINGUAGEM & CAMPO DO ENSINO \\
2 & & \\
\hline E2 & LÍNGUAS & ENSINO-APRENDIZAGEM \\
3 & & \\
\hline E2 & LÍNGUA PORTUGUESA & ENSINO \\
4 & & \\
\hline E2 & LÍNGUAS & ENSINO E APRENDIZAGEM \\
5 & & \\
\hline E2 & LÍNGUAS & ENSINO DE \\
6 & & \\
\hline E2 & LÍNGUAS & \\
\hline 7 & & ENNTINOXTO DE ENSINO \\
\hline E2 & LÍNGUA(GEM) PORTUGUÊS & \\
\hline 8 & - LÍNGUA MATERNA & \\
\hline 92 & LÍNGUA & \\
\hline E3 & & \\
0 & & \\
\hline E3 & & \\
\hline
\end{tabular}




\subsubsection{Quando o nome é Linguagem}

Linguagem, linguagens, comunicação, língua e linguística. Uma área, uma forma, um processo, um código e uma ciência.

As diferentes concepções de Linguagem têm delineado outros conceitos relacionados à Educação, como o ensino.

Travaglia (1996) faz uma sintese sobre as concepções de linguagem e suas interferências nas concepções de gramática e de ensino, que eu recupero aqui.

A linguagem como "expressão do pensamento" é uma concepção referencial, nascida na filosofia da linguagem ideal de Frege (1848-1925) e Russell (1872-1970). Era atrelada a essa visão que os jesuitas catequizaram e alfabetizaram os índios no Brasil, quando aqui chegaram. Mesmo depois da expulsão dos jesuitas e com a instituição do Português como idioma oficial do Brasil (1759), o seu ensino continuou a seguir os mesmos moldes do ensino do Latim (gramática, retórica e poética), e os objetivos continuavam sendo hierarquizar e elitizar a sociedade, cada vez mais. O ensino era prescritivo e a gramática ensinada, a normativa.

Essa abordagem se assenta sobre um subjetivismo individualista (BAKHTIN/VOLOCHÍNOV, 2006), que supõe um sujeito senhor absoluto do conhecimento, responsável pelo sucesso da comunicação, capaz de controlar o dizer, e que o faz de forma monológica, sem ser afetado pelo outro. Assim, falar e escrever bem, primeiro, são resultados de um "pensamento organizado" e, segundo, estão associados a conhecer as normas da gramática tradicional regras e conceitos. Ler, nesse ambiente, é ser capaz de recuperar o pensamento 
do autor, de um texto pronto e acabado, com um único sentido possivel: o certo.

No ensino de Língua Portuguesa no Brasil, essa configuração se manteve até a LDB 4024/61 e para além dela, na qual o objetivo da educação era desenvolver o raciocínio e as atividades de expressão da criança, proporcionando sua integração aos meios físico e social, e valorizando a criatividade para o desenvolvimento da comunicação. A formação do magistério era norteada pelo desenvolvimento de conhecimentos técnicos para a educação infantil.

$\mathrm{Na}$ década de 70, na LDB 5692/71, inspirada em uma pedagogia tecnicista e vinculando o ensino à qualificação para o trabalho, a disciplina Português passou a ser chamada Comunicação e Expressão, no primário, e Comunicação e Expressão em Língua Portuguesa, no ginásio. Essa mudança é resultado de uma concepção mais pragmática de linguagem, como instrumento de comunicação: a língua é tomada como um código que tem uma estrutura e que funciona a partir de regras específicas. É uma visão estruturalista da linguagem, pautada nas contribuições das dicotomias apresentadas por Saussure e da Teoria da Comunicação, de Roman Jakobson (1896-1982).

Essa abordagem se assenta em pressupostos do objetivismo abstrato (BAKHTIN/VOLOCHÍNOV, 2006): a linguagem está exterior ao ser, que deve internalizá-la, assim como o conhecimento. Isso devia ser feito pela repetição de modelos. Ler, então, é interpretar o código (os signos linguísticos), participando do esquema da comunicação, no qual o emissor tem uma intenção, que deve ser codificada, e, depois, decodificada pelo receptor exatamente da mesma maneira que o emissor competente intencionou. A escrita também segue a orientação dos modelos estabelecidos que, nesse momento, são os tipos textuais, e o ensino passa a ter um caráter descritivo (das estruturas e do funcionamento do código, que é a língua), além do prescritivo, assim como a gramática ensinada. 
Nos anos 1980, a propagação das linguísticas discursivas e de outras correntes linguísticas gera ambientes de reflexão sobre o ensino de língua, concepções de (ensino da) leitura, (eficácia do) ensino de gramática e temas afins. A concepção de linguagem que resulta desse momento é como processo de interação social, de caráter dialógico e ideológico, afetada por uma teoria enunciativo-discursiva (já não mais, como as duas anteriores, em correntes do pensamento filosófico-linguístico).

Essa nova tendência dos estudos da linguagem se consolida na LDB 9394/96, que propõe o texto como objeto de estudo da disciplina Língua Portuguesa, considerando a sua constituição polifônica e o contexto, que passa a ser a referência para o que seja considerado adequado ou inadequado, no uso da língua. O trabalho com a escrita passa a abranger gêneros discursivos, e a leitura passa a ser o resultado de uma coprodução de sentidos, considerando os diversos contextos que a determinam - de produção, de circulação e de recepção. O ensino deve ser produtivo, deslocando (do professor) para o aluno o lugar de centralidade no ensino.

Geraldi (2004, p.45) afirma que "uma diferente concepção de linguagem constrói não só uma nova metodologia, mas, principalmente, um 'novo conteúdo' de ensino". E é por, mais que concordar, acreditar nessa afirmação, que eu abri um espaço nesta tesa para recuperar, ainda que muito brevemente, o desenvolvimento da concepção de linguagem e como esse movimento afetou não só as concepções de gramática e de ensino, mas também de leitura e de escrita.

Só que, se essa discussão necessária demora a sair do ambiente das universidades para chegar às escolas, demora mais ainda a tocar os livros didáticos, que continuam a orientar o trabalho do professor. Sem contar que, na circulação, muita coisa chega em forma de equívocos. Digo isso porque essa terceira vertente da concepção de linguagem foi responsável, ao mesmo tempo, por produzir um grande avanço no ensino de Português, como também por 
criar uma tendência na qual falar de gramática normativa representava um retrocesso. Sem poder mais repetir o que estava instituído e sem saber o que fazer em lugar de, a aula de Português e seu objeto de estudo, o texto, virou uma terra de ninguém, na qual tudo era possivel.

Tendo considerado esse percurso, retomo ao Quadro 2:

\subsubsection{Quando o nome é Educação}

Linguagem, linguagens, comunicação, língua e linguística. Uma área, uma forma, um processo, um código e uma ciência.

Partindo desse primeiro delineamento e depois do percurso sobre as concepções de linguagem e aquilo que, dessas concepções, toca mais delicadamente a educação, como o ensino, há, aparentemente, especificidades nas substituições que moldam as feições das linhas de pesquisa. Embora só os nomes não possam me trazer respostas, como imagens, me apresentam miçangas possiveis: cinema, artes plásticas e música são miçangas que compõe, com "linguagens", territórios que estão fora da linguagem nossa de dias de semana ${ }^{18}$, que requerem especificidades que a linguagem verbal, do dia a dia, sozinha, não contempla.

Da mesma forma, "comunicação", sugere tanto um colar cuja composição exponha um desenho mais funcionalista da linguagem (remetendo à segunda concepção), como também colares com miçangas da área do Jornalismo, da Publicidade e do Cinema, que, em algumas universidades, são braços dos cursos de Comunicação.

\footnotetext{
18 Expressão usada no conto Famigerado (In: Primeira estórias, 2001), de Guimarães Rosa.
} 
Essas duas primeiras ocupações da posição "Linguagem" nos nomes das linhas de pesquisa propõe (pelo próprio plural, até) um alargamento tanto das fronteiras da linguagem verbal, quanto da área de Letras (se aproximando das Artes e do Jornalismo, por exemplo), abarcando territórios outros: os gêneros não verbais e os mistos, como obras de arte, peças publicitárias, filmes, música, vitrines e uma infinidade de outros objetos de estudo. Acontece que, na conjunção com os pares que ocupam a posição "Educação" na articulação, há um encerramento (e não uma extensão): inovações pedagógicas (E4), culturas escolares (E7), práticas educativas (E11), aprendizagem (E13) e ensino (E21) trazem a articulação para algo que é do ambiente da Educação: para a metodologia do ensino, para a escola, para a técnica de ensinar e aprender e para os instrumentos usados para isso.

Considerando essa maioria, os dois nomes (das linhas de pesquisa) que associam comunicação e educação (E15 e E16) acabam se aproximando dessa possibilidade, que é a de que a associação aconteça da seguinte forma: objetos e instrumentos próprios de outras áreas estejam sendo trazidos para a sala de aula. A linha de pesquisa que associa linguagens e construção do conhecimento pode remeter a essa mesma possibilidade, talvez no que se refira aos aportes teóricos. Não é a linguagem em si que está no centro do interesse da pesquisa, mas a sua utilidade na sala de aula.

A linha Linguagem e utopias (E14) não se encaixaria nessa possibilidade - é a que escapa (tratarei dela mais adiante).

Nas linhas em que "línguas"19" assume a posição de Linguagem (E20, E22, E23, E24, E25, E26, E27, E28, E29, E30 e E31) e, na posição de Educação aparecem "ensino" (e aprendizagem, contexto de e campo de), a restrição é ainda maior, no que se refere à possibilidade de que pudesse haver uma ampliação da área de Letras, no caso de a articulação Linguagem e

19 Incluí "linguística aplicada", "práticas de linguagem", "língua portuguesa" e "língua(gem)Português - língua materna". 
Educação fosse um campo de diálogo com as Artes e o Jornalismo. Mas, ao contrário, nesses casos, a articulação parece se referir ao ensino de línguas, materna ou estrangeira.

No entorno do centro da articulação, há conflitos que se expressam por alguns acréscimos que, por dizerem mais do mesmo, acabam, a um só tempo, não acrescentando nenhuma especificidade à articulação Linguagem e Educação como um novo campo ou uma nova área de pesquisa, como também indo na contramão da articulação, na medida em que comprime e torna difusos os interesses de investigação da linha de pesquisa. São casos como em E4 ("linguagens e diversidade cultural"), E6 ("linguagem e literatura"/"educação e sociedade"), E10 ("produção de linguagens e de identidades"), E13 ("cultura escrita e linguagens") e em E19 (“abordagens pedagógicas e ensino"). São alguns exemplos que mostram que o uso, apenas, de expressões que pertencem a temas (sociais e, portanto, da Educação também) que estão em voga, por mais relevantes que esses temas sejam, não garante a construção de um conhecimento sobre esses conteúdos.

Esses contornos ratificam a Educação como um ambiente dentro do qual a Linguagem se movimenta. A Linguagem, esse objeto material constituído na articulação, é tomada como portadora de multiplicidade; é multidimensional; é expressão, inovação tecnológica e é, também, cultura (aí inseridas a literatura e as artes em geral), e possui aspectos práticos (a língua e suas variedades e modalidades). Já a Educação é compartimentada em metonímias que se constituem, nesse caso, mais como hipônimos: níveis de escolarização; processos de ensino/aprendizagem; alfabetização e letramento (onde estão localizados os ensinos de leitura e de escrita); práticas sociais (enquanto contexto); construção do conhecimento (sobre aprendizagem). E utopia. 
As ementas corroboram com essa primeira análise:

\begin{tabular}{|c|c|}
\hline E2 & $\begin{array}{l}\text { Estuda questões relacionadas com o processo de ensino- } \\
\text { aprendizagem das linguagens oral, escrita, visual e matemática } \\
\text { na educação formal e não formal. }\end{array}$ \\
\hline E4 & $\begin{array}{l}\text { Estudos da linguagem como expressão, significação e } \\
\text { comunicação, das inovações metodológicas e tecnológicas e da } \\
\text { diversidade na prática docente. }\end{array}$ \\
\hline E5 & $\begin{array}{l}\text { Investiga as relações entre linguagem, cultura e cognição } \\
\text { focalizando a linguagem em suas diferentes perspectivas. Aborda } \\
\text { também a construção do conhecimento, o ensino aprendizagem, } \\
\text { a leitura e a escrita e a formação de professores. }\end{array}$ \\
\hline E7 & $\begin{array}{l}\text { Contempla estudos sobre Alfabetização, Letramento, Literatura } \\
\text { Infantil, Formação do Leitor, EJA, Corporidade e Ludicidade no } \\
\text { Espaço Escolar, com influência sobre diversas dimensões que } \\
\text { abrangem as relações da criança consigo, com outros e com o } \\
\text { mundo. }\end{array}$ \\
\hline E8 & $\begin{array}{l}\text { Preocupa-se em investigar a construção dos conhecimentos } \\
\text { linguísticos, culturais e sociais no cotidiano das relações } \\
\text { educativas, orientadas por abordagens sociológicas, psicológicas, } \\
\text { históricas e linguísticas. }\end{array}$ \\
\hline $\begin{array}{c}\text { E1 } \\
0\end{array}$ & $\begin{array}{l}\text { Tem como eixo central a linguagem verbal, o estudo de sua } \\
\text { natureza e relações com a sociedade, a cultura e a história. } \\
\text { Pesquisa problemas como: apropriação da linguagem oral e } \\
\text { escrita; espaços educativos, políticas linguísticas, variação e } \\
\text { diversidade. }\end{array}$ \\
\hline $\begin{array}{c}\mathrm{E} 1 \\
1\end{array}$ & $\begin{array}{l}\text { Investigam-se práticas educativas e diferentes formas de } \\
\text { linguagens presentes no mundo contemporâneo, em diferentes } \\
\text { suportes tecnológicos, considerando que em todos os espaços } \\
\text { educativos são construídos conhecimentos e uma grande cadeia }\end{array}$ \\
\hline
\end{tabular}

$20 \mathrm{O}$ texto das ementas foi mantido exatamente como encontrado no site, incluindo a grafia e a pontuação. 


\begin{tabular}{|c|c|}
\hline & o. \\
\hline $\begin{array}{c}\mathrm{E} 1 \\
3\end{array}$ & $\begin{array}{l}\text { A linha de pesquisa privilegia investigações sobre os processos } \\
\text { de escolarização, aquisição da linguagem oral e escrita, as } \\
\text { relações entre escolarização e linguagem, entre outras. }\end{array}$ \\
\hline $\begin{array}{c}\mathrm{E} 1 \\
4\end{array}$ & $\begin{array}{l}\text { Inaugura um campo de possibilidades de reinvenção das } \\
\text { linguagens, das culturas e das utopias. Busca compreenção dos } \\
\text { processos educativos formais e não formais que envolvem o fazer } \\
\text { docente e os entornos dos contextos educacionais. }\end{array}$ \\
\hline $\begin{array}{c}\mathrm{E} 1 \\
5\end{array}$ & $\begin{array}{l}\text { Estudos e pesquisas sobre os processsos de comunicação na } \\
\text { produção da existência humana e da educação, em especial, } \\
\text { sobre as mediações das tecnologias atuais da informação e da } \\
\text { comunicação na ação pedagógica. }\end{array}$ \\
\hline $\begin{array}{c}\text { E1 } \\
6\end{array}$ & $\begin{array}{l}\text { Investiga as interfaces entre educação, comunicação e } \\
\text { tecnologia, com ênfase no estudo, desenvolvimento e avaliação } \\
\text { de propostas pedagógicas desenvolvidas em cenários de } \\
\text { educação formal, não-formal, presencial, a distância, inicial e } \\
\text { continua. }\end{array}$ \\
\hline $\begin{array}{c}\text { E1 } \\
9\end{array}$ & $\begin{array}{l}\text { Conceitos e prát. de leitura. Proc. de letramento. Leitura } \\
\text { e repr. sociais. A prod. textual escrita nas sér. iniciais do E. F. } \\
\text { Estr. de comunicação. Inserção dos meios de com. na escola } \\
\text { bras. A ed. de crianças de } 0 \text { a } 10 \text { anos na perspect. hist. } \\
\text { cultural. }\end{array}$ \\
\hline $\begin{array}{c}\text { E2 } \\
0\end{array}$ & $\begin{array}{l}\text { Estudo de questões teóricas e empíricas sobre o ensino e } \\
\text { aprendizagem de língua materna e estrangeira dentro de uma } \\
\text { perspectiva discursiva e sócio-cultural com foco em: formação de } \\
\text { professores, crenças/representações sociais de professores e } \\
\text { alunos. }\end{array}$ \\
\hline $\begin{array}{c}\mathrm{E} 2 \\
1\end{array}$ & $\begin{array}{l}\text { Promover a discussão de questões relacionadas ao ensino de } \\
\text { Lingua e literatura articuladas com as diferentes formas de } \\
\text { linguagens. A ideia central é propiciar mecanismos de reflexão } \\
\text { sobre as práticas de ensino de linguagens. }\end{array}$ \\
\hline $\begin{array}{c}\mathrm{E} 2 \\
2\end{array}$ & $\begin{array}{l}\text { investigações, em diferentes perspectivas teóricas, relacionadas } \\
\text { a:formação de professores, práticas avaliativas, material } \\
\text { didático, entre outros. }\end{array}$ \\
\hline $\begin{array}{c}\text { E2 } \\
3\end{array}$ & isas que enfoquem aspectos de \\
\hline E2 & ao e \\
\hline
\end{tabular}




\begin{tabular}{|c|c|}
\hline 4 & $\begin{array}{l}\text { do em vista sua complexidade e dimensão: aspectos } \\
\text { amaticais e lingüísticos, perspectivas estilísticas e semióticas, } \\
\text { m como as questões de leitura, livro didático e produção de } \\
\text { tos. }\end{array}$ \\
\hline $\begin{array}{c}\mathrm{E} 2 \\
5\end{array}$ & $\begin{array}{l}\text { Com base em estudos de Linguística Aplicada, esta linha de } \\
\text { pesquisa pretende reunir e estimular projetos voltados para } \\
\text { processos de ensino e aprendizagem de linguas materna e } \\
\text { estrangeiras. }\end{array}$ \\
\hline $\begin{array}{c}\text { E2 } \\
6\end{array}$ & $\begin{array}{l}\text { Estudos sobre o ensino-aprendizagem de línguas e de suas } \\
\text { respectivas literaturas. }\end{array}$ \\
\hline $\begin{array}{c}\text { E2 } \\
7\end{array}$ & $\begin{array}{l}\text { Linha de reflexão com dois eixos temáticos: 1. língua(gem) no } \\
\text { contexto das práticas sociais contemporâneas; } 2 \text {. formação de } \\
\text { professor, focando a construção de saberes e de objeto de } \\
\text { ensino. }\end{array}$ \\
\hline $\begin{array}{c}\mathrm{E} 2 \\
8\end{array}$ & $\begin{array}{l}\text { a natureza e/ou a descrição } \\
\text { ntexto das práticas sociais e } \\
\text { a formação e a prática do } \\
\text { ) de ensino e de identidades. }\end{array}$ \\
\hline $\begin{array}{c}\mathrm{E} 2 \\
9\end{array}$ & $\begin{array}{l}\text { lguês nos } \\
\text { ntático e } \\
2 .\end{array}$ \\
\hline $\begin{array}{c}\text { E3 } \\
0\end{array}$ & $\begin{array}{l}\text { Estudos sobre multiletramentos e ensino de línguas, abordando } \\
\text { gêneros impressos e digitais; o texto em diferentes perspectivas, } \\
\text { contextos, modalidades e mídias; o trabalho docente e os } \\
\text { recursos instrucionais. }\end{array}$ \\
\hline $\begin{array}{c}\text { E3 } \\
1\end{array}$ & $\begin{array}{l}\text { Abrange uma multiplicidade de aspectos } \\
\text { estudos lingüísticos e literários voltados ao Ensino- } \\
\text { aprendizagem do Português como lingua materna e como lingua } \\
\text { estrangeira (PLE). Seu principal objetivo é formar profissionais } \\
\text { capazes de lidar com as linguagens, de forma critica, reflexiva e } \\
\text { ética, no âmbito do Ensino e da pesquisa, conscientes de sua } \\
\text { inserção na sociedade. }\end{array}$ \\
\hline
\end{tabular}

A abrangência da concepção de linguagem não está contemplada no seu plural. "Linguagens" refere-se, nas ementas, a 3 coisas: língua portuguesa (aquisição da escrita, análise dos níveis de organização e, muito raramente, 
como lingua estrangeira - E20, E21, E23, E24, E25, E26, E29, E31), linguas estrangeiras e tecnologias (ambientes digitais, usos da informática como instrumento de ensino, plataformas de educação a distância etc - E4, E11, E15, E16, E30). Na interface com a Educação, delineia o campo de investigação: educação infantil e primeiros anos da educação básica (E7, E13, E19), educação não-formal (E2, E10, E14) e formação de professores (E5, E20, E22, E28). A linha de pesquisa "Práticas de linguagens no campo de ensino" faz, de uma certa forma, uma síntese do que seja essa interface, nesse sentido de objeto ou instrumento/campo, quando propõe, na ementa, como objetos de análise, materiais didáticos e avaliações.

Há pontos em que a certa confusão que a definição corrente de linguagem como instrumento de comunicação gerou - tudo o que serve para comunicar - fica evidente, no que se refere à falta de clareza nos textos das ementas, como "ensino-aprendizagem das linguagens oral, escrita, visual" (E2), "linguagem como expressão, significação e comunicação" (E4), "linguagem em suas diferentes perspectivas" (E5), "processos de comunicação na produção da existência humana" (E15).

\subsubsection{A meada}

Como o fio - o ensino - não parece assim como aparece, precisei retornar no processo de fiação, porque nem o fio nem as miçangas começaram ali, no colar. Houve antes, para o fio, uma meada, de onde ele foi sendo fiado para se expor aqui, em um metafórico colar. Voltando aos fundamentos, encontro a plantação de onde foram colhidos o que era para ser fibra, e tudo enrolado em meadas. E é assim que ainda como fio de meada, o ensino dá nuances de início, nos apostos que são usados para explicar ou delimitar algo dos nomes das linhas de pesquisa ou de suas ementas (Quadros 4 e 5): 


Quadro 4: O aposto nos nomes das linhas de pesquisa
\begin{tabular}{|c|l|}
\hline E8 & $\begin{array}{l}\text { Linguagens, cultura e construção do conhecimento: perspectivas } \\
\text { histórica e contemporânea }\end{array}$ \\
\hline $\begin{array}{c}\text { E1 } \\
\text { 0 }\end{array}$ & $\begin{array}{l}\text { Linguagem: processos de produção de linguagens, identidades } \\
\text { culturais e práticas educativas }\end{array}$ \\
\hline $\begin{array}{c}\text { E2 } \\
4\end{array}$ & $\begin{array}{l}\text { Ensino da língua portuguesa: história, políticas, sentido social, } \\
\text { metodologias e pesquisa }\end{array}$ \\
\hline
\end{tabular}

Quadro 5: O aposto nas ementas das linhas de pesquisa

\begin{tabular}{|c|l|}
\hline E9 & $\begin{array}{l}\text { Desenvolve pesquisas acerca de várias temáticas ligada ao } \\
\text { ensino e aprendizagem da língua portuguesa: práticas de } \\
\text { alfabetização e letramento; formação de professores, avaliação } \\
\text { educacional; propostas curriculares; entre outras. }\end{array}$ \\
\hline E1 & $\begin{array}{l}\text { Tem como eixo central a linguagem verbal, o estudo de sua } \\
\text { natureza e relações com a sociedade, a cultura e a história. } \\
\text { Pesquisa problemas como: apropriação da linguagem oral e } \\
\text { escrita; espaços educativos, politicas linguísticas, variação e } \\
\text { diversidade. }\end{array}$ \\
\hline E2 & $\begin{array}{l}\text { Abordagem dos principais problemas referentes ao ensino da LP, } \\
\text { tendo em vista sua complexidade e dimensão: aspectos } \\
\text { gramaticais e lingüísticos, perspectivas estilísticas e semióticas, } \\
\text { bem como as questões de leitura, livro didático e produção de } \\
\text { textos. }\end{array}$ \\
\hline
\end{tabular}

Tradicionalmente, tratando diretamente do aposto, é um termo considerado como acessório na construção sintática da frase, com uma redundância tal, que pode ser retirado dela, sem que haja prejuízo no seu entendimento. Já estudos contemporâneos reconhecem, nesse elemento, o status de recurso discursivo, o que significa analisá-lo no lugar de seu acontecimento e considerando a interação entre sujeitos.

$\mathrm{Na}$ gramática tradicional, o aposto é definido e identificado pela sua forma (critério morfológico - substantivo ou frase, marcado, na escrita, por uma vírgula), pela disposição deste, na frase (critério sintático - a-posto, posto junto 
a um sujeito, objeto etc) e pela relação que ele estabelece com os outros termos (critério semântico ${ }^{1}$ - explicação ou equivalência). Esses critérios, no entanto, não dão conta do aposto no discurso. A própria hierarquia entre o que seja o “principal” e o que seja o "acessório" não funciona dessa maneira, na dimensão discursiva.

Em versões mais atualizadas, o aposto vai tomando feições desenhadas mais fortemente de acordo com sua carga semântica e de acordo com as suas funções no discurso. Azeredo (2000), por exemplo, faz uma leitura diferenciada das tipologias, considerando o valor discursivo do aposto, como o de reiterar identidades; comentar, avaliando ou esclarecendo uma informação; topicalizar, particularizar, realçar, detalhar ou sintetizar um enunciado. Nessa mesma dimensão, o aposto funciona, também, e diferentemente, como uma "estratégia de progressão discursiva" (KOCH, 2003), corroborando com o desenvolvimento de um texto, na medida em que pode tanto lhe dar continuidade, como lhe oferecer a retomada de referentes, em um processo discursivo.

Assim, nos nomes das linhas de pesquisa e nas ementas em que aparece um aposto, busquei vê-lo em sua dimensão discursiva e analisar que contribuições ele oferece à articulação Linguagem e Educação.

Embora quanto à forma pareça haver quatro linhas de pesquisa cujos nomes contêm um aposto, vou considerar apenas três, visto que em E20, "Linguística aplicada: ensino e aprendizagem de língua materna e estrangeira", o termo que tem a aparência de aposto, por conta da pontuação e da organização do texto é, de fato, um complemento nominal, cuja preposição (ao, no caso) foi omitida e substituída inadequadamente por um sinal de pontuação. Nessa mesma linha de pesquisa, acontece o mesmo na sua ementa: "Estudo de questões teóricas e empíricas sobre o ensino e aprendizagem de língua materna

${ }^{21}$ A tipologia do aposto estabelecida por um critério semântico varia entre autores, como por exemplo: Lima (1992) distingue os tipos de esclarecimento, de denominação, de enumeração e de sintese; Cunha e Cintra (1985) apontam os tipos especificativo, enumerativo e recapitulativo; e Bechara (1999) assinala os tipos enumerativo, distributivo e circunstancial. 
e estrangeira dentro de uma perspectiva discursiva e sócio-cultural com foco em: formação de professores, crenças/representações sociais de professores e alunos". Desta vez, o uso facultativo do sinal de pontuação parece uma escolha.

Em E8, o referente que o aposto particulariza é a construção do conhecimento sobre a interface entre a linguagem e a cultura. Pelo aposto se entende, então, que "construção do conhecimento" não tem, no nome da linha, a mesma função que têm "linguagem" e "cultura" - sujeitos relacionados -, mas refere-se a um resultado dessa interface. A linha de pesquisa revela, se bem entendido o aposto, o interesse pela pesquisa sobre a história dessa interface. A ementa dessa linha de pesquisa, no entanto, não descreve essa interpretação. Diz que a investigação da linha é sobre "a construção dos conhecimentos linguísticos" e sobre a (construção dos conhecimentos) "culturais", "orientadas por abordagens sociológicas, psicológicas, históricas e linguísticas". Nesse cotejamento, o aposto adorna, apenas, o nome. Não exatamente no sentido que a gramática tradicional the deu - de acessório - mas no sentido de que não reitera nem esclarece nem acrescenta qualquer coisa sobre particularidades da linha, uma vez que a perspectiva histórica - e nela está incluída o status contemporâneo - é, não raro, parte de um processo de "construção do conhecimento" de um objeto científico.

Em E10, o aposto enumera o que da linguagem constitui o foco de investigação principal da linha - produção de linguagens, de identidades culturais e práticas educativas que envolvam, de alguma forma, as linguagens e identidades produzidas. A ementa dessa linha (Quadro 5) corrobora essa leitura. No aposto que aparece nessa mesma linha, mas agora em sua ementa, especifica ainda mais o seu interesse investigativo, que são os problemas na aquisição da linguagem (entendo que em processos de alfabetização); problemas no que se refere a espaços educativos e como as politicas linguísticas tratam problemas como a variação e a diversidade. Esse tratamento é pouco ortodoxo no que se refere a esses temas, e "produção de linguagens" é algo que a mim, 
sempre me parece extremamente vago e confuso, principalmente quando se trata de uma relação sinonímica com "aquisição da escrita", no nivvel de alfabetização.

O aposto que aparece em E24 é, dos três que aparecem nos nomes, o que mais se adequa a sua função discursiva (do aposto). Ele ajuda a esclarecer a identidade da linha, detalhando o que do ensino de lingua compõe eixos de estudo, tecendo um perfil investigativo. Há um aposto que aparece também na ementa dessa linha, que detalha o que seriam as dimensões do ensino de Lingua Portuguesa considerados problemas - os seus niveis de organização, a leitura e a produção de textos. Entendo que livro didático, embora apareça na sequência, pode constituir um problema referente ao ensino da Língua Portuguesa, mas não uma dimensão.

O aposto que aparece na ementa E9 explicita, em um primeiro momento, o que está contemplado em várias temáticas ligadas ao ensino e aprendizagem da língua portuguesa. No entanto, ao final da ementa, a generalidade é que é reiterada, com a expressão entre outras.

Por isso, ainda meada, de onde, e só a partir de onde, pude começar a analisar o colar, em cujo interior, estava meu objeto de pesquisa que, mesmo depois de fiado, ainda se ocultava por entre miçangas que estavam ali, independente da minha escolha, porque o colar não fora criado, antes, por mim.

\subsubsection{O novelo}

Assumo que esse estudo sobre os apostos nas linhas de pesquisa me mostrou pouco do que eu esperei ver. Assinalo quatro pontos que, na verdade, foram reiterações do que eu havia concluido vendo apenas a forma como 
Linguagem e Educação foram articulados nos nomes e nas ementas: a primeira é que não há, até o momento, qualquer indício de que essa articulação se configure em uma nova área; a segunda é que, mesmo na articulação, as especificidades de uma e outra área são mantidas, o que é corroborado pela inserção, não raro repentina (como "livro didático", em E24), de uma expressão de uma ou outra ou pelo emprego de expressões genéricas (como "várias temáticas", em E9) para justificar a articulação; a terceira é que não há uma concepção de linguagem que oriente a formação de um perfil de uma área; por fim, a quarta observação é que a articulação acontece, sobretudo, pela instituição da linguagem (aquisição ou desenvolvimento dela) como objeto de estudo da educação, o que significa que a linguagem é investigada em ambientes de educação, seja no que se refere a espaço físico (como "espaços educativos", em E10), como ambiente teórico (como "sentido social", em E24).

Assim, na posição Linguagem, no que se refere aos nomes das linhas de pesquisa, estão: linguagens, práticas de linguagens, lingua materna, comunicação, língua e linguística, dissolvendo limites entre área, forma, processo, código e ciência. linguística. Nessa posição, Linguagem é, sobretudo, a língua. E no que diz respeito à língua, o interesse das linhas de pesquisa está voltado para a sua aquisição e para o conhecimento da sua estrutura, da perspectiva de estudar, investigar, discutir, abordar e analisar para ensinar.

$\mathrm{Na}$ sua interface com a Linguagem, a denominação "área", no que se refere à Educação, parece ter sido levada a último termo - espaço físico. Nesse espaço, de acordo com o que está nas ementas, a Linguagem é um instrumento através do qual se olha para a área da Educação, ou objeto de estudo sob uma perspectiva técnica da Educação. E Educação - que é, ainda de acordo com o texto das ementas, o que acontece no ambiente da escola - ou num ambiente de ensino; é um conceito que se congrega antes a um espaço, que a um resultado ou a um processo. 
Mesmo assim, há um fio que começa a se mostrar, começando, agora, nessas primeiras tramas, ainda na meada. Uma paragem na viagem - imagem e promessa de fio. 


\section{DA TEIA PARA O TEAR: O ENREDAMENTO DAS VOZES NA TRAMA DO DIÁlOGO}

Um galo sozinho não tece a manhã: ele precisará sempre de outros galos. De um que apanhe esse grito que ele e o lance a outro: de um outro galo que apanhe o grito que um galo antes e o lance a outro; e de outros galos que com muitos outros galos se cruzam os fios de sol de seus gritos de galo para que a manhã, desde uma tela tênue, se vá tecendo, entre todos os galos.

(MELO NETO, 1979, p.217)

Olho para a minha coleção, observo o colorido das miçangas e quase posso ouvir a melodia delas na composição do colar. Como vozes, passam a sujeitos de um diálogo e, cada uma, mesmo com sua cor, seu tom, ocupa uma posição enunciativa.

Assim como os gritos de galos se cruzam em fios de vozes para tecer a manhã, quero ouvir, nesta pesquisa, a sinfonia que resulta dessa harmonia/desarmonia; onde estão e para onde vão seus ecos: o que é produzido no cruzamento de (fios de) vozes que tecem a articulação entre Linguagem e Educação; onde há um tom e onde ele destoa.

Há outras miçangas que aparecem na composição dos colares - outros tons, outras vozes em fio, que vão tecendo manhãs e colares: são outras áreas que agregam, à Linguagem e Educação, temas (Quadro 6) que, ampliando os limites do que sejam objetos de áreas especificas, podem contribuir na construção de um perfil da articulação, como nova área. 


\begin{tabular}{|c|c|c|}
\hline & Tema & Escopo \\
\hline E4 & $\begin{array}{l}\text { Diversidade } \\
\text { cultural }\end{array}$ & (Estudo) da diversidade na prática docente \\
\hline E5 & Conhecimento & $\begin{array}{l}\text { (relação entre linguagem e) Cognição; Construção do } \\
\text { conhecimento }\end{array}$ \\
\hline E6 & $\begin{array}{l}\text { Literatura e } \\
\text { sociedade }\end{array}$ & $\begin{array}{l}\text { Estudos literários como objeto de estudo; sociedade como } \\
\text { práticas sociais }\end{array}$ \\
\hline $\mathrm{E} 8$ & $\begin{array}{l}\text { Cultura e } \\
\text { conhecimento }\end{array}$ & $\begin{array}{l}\text { Construção dos conhecimentos (linguísticos, culturais e } \\
\text { sociais) }\end{array}$ \\
\hline E10 & $\begin{array}{l}\text { Identidades } \\
\text { culturais }\end{array}$ & $\begin{array}{l}\text { A natureza da linguagem verbal e suas relações com a } \\
\text { sociedade, a cultura e a história; Políticas linguísticas, } \\
\text { variação e diversidade }\end{array}$ \\
\hline E11 & Tecnologia & $\begin{array}{l}\text { Formas de linguagens no mundo contemporâneo; suportes } \\
\text { tecnológicos }\end{array}$ \\
\hline E14 & Culturas & Reinvenção (das culturas) \\
\hline E16 & Tecnologia & Interfaces entre educação, comunicação e tecnologia \\
\hline E26 & Literaturas & Objeto de ensino-aprendizagem \\
\hline E30 & Tecnologia & Gêneros impressos e digitais; midias; recursos instrucionais \\
\hline
\end{tabular}

A presença dessas outras áreas promovem um cruzamento de fios (d)e vozes: as áreas chamadas pela Linguagem e Educação para a composição estão dentro da Grande Área das Ciências Humanas e da Grande Área das Ciências Sociais Aplicadas.

A articulação entre Linguagem e Educação é traspassada por temas do interesse da Antropologia, da Filosofia, da Psicologia, da Sociologia, da História, da Geografia, Ciências Políticas, Ciências da Informação e Comunicação miçangas para o meu colar, parte do diálogo entre efeitos das miçangas, sujeitos da constituição do colar. Poderia trazer uma discussão sobre interdisciplinaridade, mas é meu desejo continuar no figurativo da metáfora. 
Cultura, por exemplo, que está presente em E4, E8, E10 e E14, e suas derivações (diversidade cultural, identidade cultural, culturas etc) é um conceito da Antropologia que traz para a articulação um tema do qual a História, a Sociologia e a Filosofia - mas, sobretudo, os movimentos sociais também já haviam se apropriado e que se tornou obrigatório, na Educação, a partir dos anos 1990, quando "Pluralidade Cultural" surgiu como um dos temas transversais nos Parâmetros Curriculares Nacionais (1997).

Claro está que o surgimento desse tema nos PCN's não se deu por boa vontade apenas dos curadores do MEC. De fato, o caminho é inverso - começa, muito antes, nas lutas populares, até chegar aos gabinetes. Também está claro que a presença desse tema expressa, primeiro, que ele esteve ausente da pauta da Educação durante todos esses anos e, depois, que essa presença não garante nem uma discussão adequada sobre o tema, que garanta o respeito e os direitos individuais e sociais das minorias, nem a inclusão.

A cultura estar presente nas linhas de pesquisa sobre Linguagem e Educação, da mesma forma, aponta para a possibilidade de que a linha de pesquisa tenha, de fato, interesse pela pesquisa sobre as diferenças, inclusive naquilo que a linguagem manifesta, ou de que esteja apenas tentando alcançar as expectativas do MEC.

O interesse pela Literatura colocado no ambiente da articulação pode ser pelo viés dessas diferenças também. A linha de pesquisa em que a Literatura aparece no nome (E6) anuncia, como objeto de estudo, os estudos literários [...] levando-se em consideração as práticas sociais, as diversas modalidades linguísticas [...]"

A linha de pesquisa E14 tem aparecido de forma recorrente nos recorte que venho fazendo até aqui. A palavra utopia, que aparece no nome da linha, tem me deixado intrigada desde o início. Ela aparece como um dos colares da minha coleção porque é uma linha de pesquisa da área de Educação, tem 
"linguagem" em seu nome e a ementa propõe que se busque a "compreensão dos processos educativos formais e não formais que envolvem o fazer docente e os entornos dos contextos educacionais". Não consigo achar, no entanto, nenhuma pista do significado de utopia nesse engendramento entre Linguagem e Educação.

O termo utopia foi criado por Thomas More (1478-1535), no romance filosófico ${ }^{22}$ sobre uma ilha (um arquipélago, na verdade) na qual haviam sido extintas as propriedades privadas e a intolerância religiosa (ABBAGNAMO, 2000, p.987) e onde todos viviam felizes. O termo passou a ser usado para designar um modelo ideal (de sociedade) destinado a realizar-se e que nunca conseguiria realizar-se (MANNHEIM, 1893-1947). Na obra, são narradas histórias por um navegador. Tomando essas informações, encontrei alguns links ${ }^{23}$ que puderam me dizer algo do que possa ser utopia nessa linha de pesquisa. O primeiro é, certamente, uma coincidência: a vocação da instituição é voltada para ecossistemas costeiros e oceânicos, devido à sua localização ${ }^{24}$. Em seguida, vi que os professores dessa linha têm trabalhos e grupos de estudo voltados para temas como gênero e sexualidade, e ministram disciplinas na pós como Feminismos e gêneros: um olhar sobre a sexualidade; Gênero, sexualidade e produção das diferenças; Gênero e infância; Visitando a história da sexualidade: a vontade de saber, o uso dos prazeres e o cuidado de si; Docência, sala de aula e alteridade; Estudos sócio-antropológicos da infância, dentre outras 25 .

Os trabalhos (dissertações) defendidos desde 2013 têm, como temas, espaços de coletividade, religiões de matrizes africanas, homofobia e inclusão, a

\footnotetext{
22 De optimo reipublicae statu deque nova insula Utopia

${ }^{23}$ Informações na página da Universidade Federal do Rio Grande, disponível em www.ppgedu.furg.br

${ }^{24}$ Extremo sul do litoral brasileiro, na cidade histórica do Rio Grande, à margem do estuário que conduz ao oceano as águas da Lagoa dos Patos e de seus afluentes. Disponivel em http://www.coperve.furg.br/index.php/a-furg

${ }^{25}$ Catálogo completo disponivel em http://www.ppgedu.furg.br/index.php/disciplinas
} 
partir de dados como narrativas de professores, narrativas infantis e narrativas de mulheres pescadoras. Daí concluí que a utopia no nome da linha de pesquisa e em acordo com o que descreve a ementa, é um convite para inaugurar um campo de possibilidades de se estudar, refletir e discutir, de fato, as diversidades, fazendo com que "o outro" possa, ele mesmo, falar com sua própria voz - ainda que seja um fio de voz -, de seu próprio lugar (CERTEAU, 2013) - uma utopia.

Essa voz em fio, a voz do outro, dá visibilidade aos conceitos de diversidade, pluralidade, tolerância e amor, e, sim, é mister compor a articulação entre Linguagem e Educação. É uma miçanga para o meu colar.

No entanto, essa voz que ecoa do espaço da diversidade é um frágil fio, que pode ser quebrado na medida em que os processos de avaliação trabalham no sentido de padronizar a educação, usando a diversidade para fins classificatórios. Esses fins são definidos por princípios da meritocracia, o que coloca a diversidade tão demandada na Base Nacional Comum em um lugar de “declaração de princípios”, promovendo não a inclusão, mas a segregação escolar.

A manhã não se tece sozinha, nem de galos iguais. Ela precisa de galos, cujos gritos de fios de sol se cruzem, para irem tecendo.

Uma serenata de galos nos tons da manhã é uma orquestra tecida de diferentes vozes que vão ali, no amanhecer, se encontrando. A ideia de cruzamento é essa mesma: um encontro de coisas distintas. Também na articulação entre Linguagem e Educação há esse momento em que fios de vozes se encontram e começam a tecer, talvez, um diálogo.

Esse lugar marcado pelo instante do cruzamento é, aqui, mais teórico do que prático; de encontro com a possibilidade de tecer colares de diálogos e manhãs: lugar do estudo, seguido da investigação/pesquisa. 


\begin{tabular}{|c|c|c|c|}
\hline 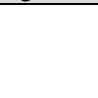 & Estudo & $\begin{array}{c}\text { Investigação / } \\
\text { pesquisa }\end{array}$ & $\begin{array}{l}\text { Compreensão / discussão / abordagem / reunião } \\
\text { / estímulo / exame }\end{array}$ \\
\hline E1 & + & - & - \\
\hline E2 & + & - & - \\
\hline E3 & $\varnothing$ & $\varnothing$ & $\varnothing$ \\
\hline E4 & + & - & - \\
\hline E5 & - & + & - \\
\hline E6 & + & - & - \\
\hline E7 & + & - & - \\
\hline E8 & - & + & - \\
\hline E9 & - & + & - \\
\hline E10 & + & - & - \\
\hline E11 & - & + & - \\
\hline E12 & + & + & - \\
\hline E13 & - & + & - \\
\hline E14 & - & - & + \\
\hline E15 & + & + & - \\
\hline E16 & - & + & - \\
\hline E17 & $\varnothing$ & $\varnothing$ & $\varnothing$ \\
\hline E18 & + & - & - \\
\hline E19 & $\varnothing$ & $\varnothing$ & $\varnothing$ \\
\hline E20 & + & - & - \\
\hline E21 & - & - & + \\
\hline E22 & - & + & - \\
\hline E23 & - & + & - \\
\hline
\end{tabular}




\begin{tabular}{|l|c|c|c|}
\hline E24 & - & - & + \\
\hline E25 & - & - & + \\
\hline E26 & + & - & + \\
\hline E27 & - & - & - \\
\hline E28 & + & - & + \\
\hline E29 & - & - & - \\
\hline E30 & + & - & - \\
\hline E31 & + & - & \\
\hline
\end{tabular}

O que escapa dessa regularidade (estudo/investigação) propõe a compreensão (dos processos do ensino de), discussão (sobre o ensino de), abordagem (de problemas relacionados ao ensino de), reunião e estímulo (de/a projetos sobre ensino de) e exame (de normas e registros com vistas ao ensino). Nenhuma dessas propostas constitui, necessariamente, um deslize significativo, pois que o estudo e/ou a investigação/pesquisa são pressupostos desses procedimentos.

A articulação entre Linguagem e Educação, nas ementas, propõe a construção de um espaço de investigação sobre um interesse específico, como as linhas de pesquisa, no geral. No caso aqui analisado, considerando que, na articulação, a Educação é o ambiente e a Linguagem é o objeto de interesse de pesquisa nesse ambiente, há um duplo na especificidade desse objeto, formado pelos processos de ensino (práticas, temáticas, recepção, questões, abordagens, aspectos, problemas) e pela formação do professor (Quadro 8): 
Quadro 8: Objeto de interesse

\begin{tabular}{|c|c|c|}
\hline & Processos de ensino & Formação do professor \\
\hline E1 & + & - \\
\hline $\mathrm{E} 2$ & + & - \\
\hline E3 & + & - \\
\hline $\mathrm{E} 4$ & + & - \\
\hline E5 & + & + \\
\hline E6 & + & - \\
\hline E7 & + & - \\
\hline E8 & - & + \\
\hline E9 & + & + \\
\hline E10 & + & - \\
\hline E11 & + & - \\
\hline E12 & + & - \\
\hline E13 & + & - \\
\hline E14 & + & - \\
\hline E15 & + & - \\
\hline E16 & + & - \\
\hline E17 & + & - \\
\hline E18 & + & - \\
\hline E19 & + & - \\
\hline E20 & + & + \\
\hline E21 & + & - \\
\hline E22 & - & + \\
\hline E23 & + & - \\
\hline E24 & + & - \\
\hline
\end{tabular}




\begin{tabular}{|c|c|c|}
\hline E25 & + & - \\
\hline E26 & + & + \\
\hline E27 & - & + \\
\hline E28 & - & - \\
\hline E29 & + & - \\
\hline E30 & + & - \\
\hline E31 & + & \\
\hline
\end{tabular}

São miçangas para o meu colar.

\subsection{OS FIOS DE VOZES: EFEITOS DA ARTICULAÇÃO DAS MIÇANGAS}

Volto a olhar para os nomes das linhas de pesquisa. Esses nomes colocam em situação de interlocução os sujeitos que dialogam: a Linguagem e a Educação, que vou marcar aqui, na enunciação, como um "eu” e um "tu”, pelas posições que ocupam; "um signo vazio que se torna cheio, desde que um locutor o assuma” (CERTEAU, 2013, p.231).

O processo enunciativo que produz a articulação entre Linguagem e Educação diz de um interesse comum entre essas duas áreas, aqui identificado como o ensino. Esse interesse comum aparece na utilização recorrente da palavra nas ementas e nos nomes das Linhas de Pesquisa, mas também na conjuminância, em um mesmo enunciado, de expressões que pertencem às esferas discursivas de uma e de outra área. Assim, o que está posto nas ementas das Linhas de Pesquisa é a descrição do que é (ou de quais são) as temáticas que lhes interessam na articulação prevista nos seus nomes; o que fica pressuposto é que essa articulação está estruturada, enquanto linha de 
investigação, de acordo com os critérios dos órgãos oficiais, nos quais estão registradas (a CAPES, no caso).

Voltando ao colar: o fio - o ensino - atravessa essas duas miçangas, as mais centrais. Miçangas maiores, mais determinantes do modelo e mais determinadas pelas vozes, temáticas, áreas e linhas. Miçangas para esta análise do colar para chegar ao fio, depois de ter desafiado a meada. Convém explicar que o fio é o ensino, as miçangas maiores Linguagem e Educação e as outras miçangas tantas quantas forem as vozes, efeitos na materialidade das ementas, nas nuances das miçangas. Chego a pensar que, diante do colar, vi tantas miçangas que quase me esqueço do fio. Porque quem olha para um colar, pouco se importa com o fio que o atravessa, mas com seus efeitos. Vem daí ter recortado as ementas, caso contrário seriam infinitas as vozes discursivas que dariam seus sinais nos efeitos de sentido da composição do colar.

Da heterogeneidade das temáticas-objeto de interesse e das outras áreas com as quais também dialogam, subtendo, no entanto, que esse campo de investigação ainda está por se estruturar; que não tem, de fato, um objeto definido, pois toma um objeto de uma esfera (a linguagem) e apenas a coloca em outra (a educação) - ou seja, não constitui um outro campo. O que tornou possivel a enunciação de uma articulação foi exatamente a sua ausência, enquanto objeto científico - uma necessidade. Apesar disso, o interesse comum - o ensino - coloca as duas áreas, na articulação, como interlocutores, em uma situação de diálogo - as ementas.

Os interlocutores são vozes que se entrecruzam no diálogo. Aqui, Linguagem e Educação são duas vozes tratadas como vozes discursivas e que adquirem uma tonalidade distinta de seus uníssonos, no diálogo que as linhas de pesquisa propõem. 
O movimento dessas vozes constitui um jogo que, examinado sob o olhar da análise do discurso, revela um sujeito descentrado (ROBIN, 1977), constituído na relação com o simbólico e cindido em efeitos de linguagem. $\mathrm{O}$ simbólico, em termos discursivos, constitui um processo de significação no qual o mesmo e o diferente apresentam-se em desordem: um jogo cujo suporte material é fluido e estabiliza e desestabiliza a sequência da cadeia significante.

Os jogos de/com a linguagem têm estado presentes no discurso de vários filósofos e teóricos: o Wittgenstein das Investigações Filosóficas (1999) chama jogos de linguagem "todo o processo do uso das palavras" (p.30), nos quais a linguagem é um instrumento, cujo conhecimento e uso (mediado por "regras da gramática") determinam sua função (que não está a priori); em Saussure (1995), a metáfora do jogo (de xadrez) aparece para ilustrar o caráter sistemático da língua, no qual as peças se movimentam a partir de regras específicas e onde não há senão valores. $\mathrm{Na}$ análise do quadro Las meninas (VELAZQUEZ, 1656), Foucault (2002) chama de jogo das metamorfoses a relação dos olhares que torna instável o lugar de sujeito e de objeto, que “invertem seu papel ao infinito" (p.5).

A definição de jogo envolve lugar, regras e jogadores. Concebida nessa relação metafórica, a articulação entre Linguagem e Educação se constitui em um jogo de vozes (Ducrot, 1987) que articula um objeto e um espaço e no qual seus sujeitos são heterogêneos.

As ementas constituem um breve resumo do que sejam as linhas de pesquisa. São textos institucionais, sem serem burocráticos, no entanto, e que têm muito pouco, para ser bem generosa, de sedutor, nas suas produções. Mas, se, por um lado, é dever das instituições de ensino superior ter trabalhos no campo da pesquisa e da extensão, para se firmarem como universidades, por outro é desejo de muitos participar desses trabalhos. Nesse sentido, deve haver algo, na oferta, que vá ao encontro do desejo do outro. 
As instituições são lugares de poder - são lugares onde o discurso é habilitado. Os cursos de pós-graduação, as linhas de pesquisa, os grupos de estudo, também. Há sempre um processo seletivo que visa escolher quem se adequa às propostas da instituição, às afinidades dos orientadores disponiveis, dentre tantas outras coisas que funcionam como interdição ao acesso dos que almejam uma pós, sobretudo em instituições públicas. A ementa pode ser considerada uma dessas práticas reguladoras, através das quais é possivel controlar o acesso. Diz Foucault (2004, p.10):

Por mais que o discurso seja aparentemente bem pouca coisa, as interdições que o atingem revelam logo, rapidamente, sua ligação com o desejo e com o poder. Nisto não há nada de espantoso, visto que o discurso - como a psicanálise nos mostrou - não é simplesmente aquilo que manifesta (ou oculta) o desejo; é, também, aquilo que é objeto do desejo; e visto que - isto a história não cessa de nos ensinar - o discurso não é simplesmente aquilo que traduz as lutas ou os sistemas de dominação, mas aquilo por que, pelo que se luta, o poder do qual queremos nos apoderar.

Há um diálogo - para além da articulação - manifestado nas ementas. Há práticas que regulam esse diálogo. Há uma relação de poder entre Linguagem e Educação, que se alternam na interlocução. E há um acordo sancionado entre as duas áreas, na medida em que são articuladas.

As ementas das linhas de pesquisa têm uma natureza polifônica: nelas convergem vozes da (área da) Educação e da (área da) Linguagem. Mas também do Governo (do seu ministério, dos seus programas etc), mais ou menos filtrados pelas universidades, que é quem as autoriza ou interdita.

O termo polifonia foi cunhado pela história da música para nomear um tipo de composição na qual diversas melodias se sobrepõem em simultâneo. Bakthin (1981) passou a utilizá-lo para referir a multiplicidade de vozes 
oriundas de distintos lugares ideológicos que no texto (de Dostoiévski) confluem, ora em harmonia, ora em desalinho, resistindo ao discurso autoral. Ducrot (1987) amplia, novamente, a abrangência do termo, para incorporá-lo ao campo dos estudos linguísticos, na elaboração de uma teoria na qual mostra a presença de enunciadores através de marcas linguísticas deixadas na enunciação, rompendo com a tradição da unicidade do sujeito. Para ele, não se trata mais do que se faz quando se fala, mas do que se considera que a fala, segundo o próprio enunciado, faz (p.163), ou seja, os efeitos da enunciação. Nas ementas, um desses efeitos é o diálogo. No Quadro 9, estão selecionadas cinco ementas de pós em cujos nomes aparecem, articulados, apenas Linguagem e Educação:

\begin{tabular}{|l|l|l|} 
Quadro 9: Linguagem educação / Educação e Linguagem: ementas \\
\hline E1 & $\begin{array}{l}\text { Educação e } \\
\text { Linguagem }\end{array}$ & $\begin{array}{l}\text { Estudo da linguagem em suas múltiplas dimensões, em } \\
\text { contextos educativos diversos e em diferentes niveis de } \\
\text { escolarização, visando à compreensão dos processos de } \\
\text { ensino e aprendizagem fundados em quatro pontos } \\
\text { essenciais. }\end{array}$ \\
\hline E3 & $\begin{array}{l}\text { Educação e } \\
\text { Linguagem }\end{array}$ & $\begin{array}{l}\text { Aspectos cognitivos, sociais e históricos das práticas } \\
\text { linguísticas, lingua portuguesa na aprendizagem escolar; } \\
\text { linguagem verbal e outras linguagens; cultura escrita, } \\
\text { alfabetização e letramento; ensino de literatura; oralidade } \\
\text { e escrita. }\end{array}$ \\
\hline E9 & $\begin{array}{l}\text { Educação e } \\
\text { Linguagem } \\
\text { E17 }\end{array}$ & $\begin{array}{l}\text { Desenvolve pesquisas acerca de várias temáticas ligada ao } \\
\text { ensino e aprendizagem da língua portuguesa: práticas de } \\
\text { avaliação educacional; propostas curriculares; entre } \\
\text { outras. }\end{array}$ \\
\hline $\begin{array}{l}\text { Linguagem e } \\
\text { Educação }\end{array}$ & $\begin{array}{l}\text { Aspectos cognitivos, sociais e históricos das práticas de } \\
\text { linguagem. Cultura escrita. Alfabetização e letramento. } \\
\text { Práticas de letramento em contexto de formação de } \\
\text { professores. Letramento acadêmico. Práticas de letramento }\end{array}$ \\
\hline
\end{tabular}




\begin{tabular}{|c|c|l|}
\hline & & relacionadas à língua materna... \\
\hline E18 & $\begin{array}{c}\text { Linguagem e e } \\
\text { Educação }\end{array}$ & $\begin{array}{l}\text { Desenvolve estudos de linguagem e de literatura, } \\
\text { focalizando questões de ensino e de aprendizagem, bem } \\
\text { como estudos referentes à arte e à comunicação em suas } \\
\text { múltiplas relações com a escola. }\end{array}$ \\
\hline
\end{tabular}

Condensando os enunciados, tem-se que a linha de pesquisa desenvolve estudos e pesquisas sobre linguagem, em ambientes de educação. Por linguagem entende-se língua, modalidades, manifestações e usos; por ambientes de educação se entende processos (alfabetização, letramento, escrita), lugares físicos, formação de professor, aspectos (sociais, cognitivos, históricos).

Todas essas cinco ementas estão vinculadas a programas de pós em Educação. Suas formatações mostram um afinamento com as ações e programas do MEC, para a Educação continuada, Alfabetização, Diversidade e Inclusão nos níveis superior, profissional e tecnológico e básico e, pelo menos nos termos das "metas qualitativas" expressas, contém elementos do discurso oficial e, nessa aproximação, pretendem estar

contribuindo para o enfrentamento das desigualdades educacionais, considerando diferentes públicos e temáticas, a saber: Educação Especial, Educação para as Relações ÉtnicoRaciais, Educação do Campo, Educação Escolar Indígena, Educação Quilombola, Educação em Direitos Humanos, Educação Inclusiva, Gênero e Diversidade Sexual, Combate à Violência, Educação Ambiental, Educação de Jovens e Adultos. As áreas de atuação da SECADI contemplam, ainda, agendas políticas de caráter intersetorial. (Disponivel em http://portal.mec.gov.br/secretaria-de-educacao-continuadaalfabetizacao-diversidade-e-inclusao/programas-e-acoes)

O lugar histórico da articulação entre Linguagem e Educação foi estabelecido anteriormente: a necessidade de a educação tocar a linguagem, no que se refere ao seu ensino, e a linguagem ressignificar a educação, na medida 
em que traz o diálogo para sua fundamentação. De certa forma, o ensino, como transmissão, sempre esteve presente no ambiente da linguagem, na escola. Como se delineia essa relação, trazida para o campo da pesquisa, na pós graduação?

Essa relação, nas ementas, está posta em três ordens: 1) a definição do objetivo, que, ao generalizar, cumpre o papel institucional da linha, que é a pesquisa na universidade. Essa ordem está contemplada em "estudos", "pesquisa" ou $\varnothing ; 2)$ a especificação do objeto, que é a linguagem, seja em nivel de aquisição, seja em nível de desenvolvimento; e 3) a orientação do objeto, sempre ligado a "contextos educativos":

\begin{tabular}{|c|c|c|c|}
\hline \multicolumn{4}{|c|}{ Quadro 10: A ordem do discurso } \\
\hline & Definição do objetivo & Especificação do objeto & $\begin{array}{c}\text { Orientação do } \\
\text { objeto }\end{array}$ \\
\hline E1 & $\begin{array}{c}\text { Estudo visando à } \\
\text { compreensão dos processos } \\
\text { de ensino e aprendizagem }\end{array}$ & Linguagem (dimensões) & $\begin{array}{l}\text { Contextos } \\
\text { educativos }\end{array}$ \\
\hline E3 & $\begin{array}{c}\varnothing \text { aspectos cognitivos, sociais } \\
\text { e históricos }\end{array}$ & $\begin{array}{c}\text { Práticas linguísticas } \\
\text { (lingua portuguesa e } \\
\text { outras linguagens) }\end{array}$ & Escola \\
\hline E9 & Pesquisa & $\begin{array}{l}\text { Lingua portuguesa (ensino } \\
\text { e aprendizagem) }\end{array}$ & $\begin{array}{l}\text { Educação } \\
\text { básica/ensino } \\
\text { superior }\end{array}$ \\
\hline E17 & $\begin{array}{c}\varnothing \text { aspectos cognitivos, sociais } \\
\text { e históricos }\end{array}$ & $\begin{array}{l}\text { Práticas de linguagem } \\
\text { (língua materna) }\end{array}$ & $\begin{array}{l}\text { Educação } \\
\text { básica/ensino } \\
\text { superior }\end{array}$ \\
\hline E18 & Estudos & $\begin{array}{l}\text { Linguagem (literatura, } \\
\text { arte, comunicação) }\end{array}$ & $\begin{array}{l}\text { Educação } \\
\text { básica/ensino } \\
\text { superior }\end{array}$ \\
\hline
\end{tabular}


Nessa ordem, os sujeitos (as posições de sujeito) são constituídos no discurso que se materializa nas ementas, de onde falam. Sendo uma unidade, as ementas não são, no entanto, unas; constituem uma unidade que se constitui da própria heterogeneidade e no interior da qual vozes (consonantes ou dissonantes) coexistem.

Além da Educação e da Linguagem, outras vozes se cruzam nas ementas e podem assumir posições diferentes na enunciação, produzindo, também, efeitos de sentido: há uma equipe de profissionais - professores, pesquisadores, técnicos e alunos, talvez, que redigem a ementa, que são responsáveis pela sua enunciação; há a instituição que autoriza e regula o que pode ser dito, de acordo com o que considera ser necessário, se aproximando mais ou menos dos discursos oficiais - as miçangas não se harmonizam sozinhas, não escolhem as posições que tomam no desenho do colar, não se fazem atravessar por um fio. O colar também não "se escolhe" produzir.

Aliás, mesmo em termos paradigmáticos, na língua, qualquer escolha é simbólica, visto que há um deslocamento do sentido usado mais comumente, ligado, ilusoriamente, à ideia de autonomia: mesmo no comportamento de eleger, discernir ou preferir estão o movimento de assinalar, marcar, apontar. Deslocada, assim, a escolha é um acatamento; é uma alienação mascarada de autonomia. E essa escolha, seja de miçangas, seja de colares, é resultado de um jogo de forças, de uma relação de poder, no cruzamento de vozes. Estou tratando aqui da escolha de quem compôs o colar que analiso.

Considerando que há um diálogo (mais que uma articulação) entre a Educação e a Linguagem na produção das ementas; considerando que o lugar dessas linhas de pesquisa que estão reproduzidas no Quadro 12, onde estão as linhas de pesquisa exatamente nomeadas Linguagem e Educação/Educação e Linguagem são os programas de pós em Educação; considerando, também, que o epíteto da articulação não tem um efeito de sentido diferenciado, passo a identificar dois sujeitos, A (Educação) e B (Linguagem), que falam, expostos em 
uma relação de interlocução, na posição de sujeitos, de um lugar de saber e de um lugar de poder.

Dos lugares de A e B, as falas não são homogêneas. O processo enunciativo que produzem as ementas visa a apresentar Linguagem e Educação como um campo de pesquisa destinado, principalmente, aos trabalhadores da educação - ou professores de línguas ou professores da educação infantil. É o que está posto. Para isso, o par é criado destacando, no percurso da articulação, um interesse comum: o ensino.

O que fica pressuposto é que existe esse campo; o que fica subtendido é que há uma necessidade que constitui esse campo. Pressupõe-se que haja uma equipe de profissionais experientes que tem o dominio da necessidade, tanto no que se refere a sua identificação, no ambiente escolar e/ou no universo acadêmico, como no que se refere aos mecanismos para suprir essa necessidade; as pessoas que aderem às linhas embarcam nessa crença. Fica, no entanto, subentendido que a formação desse campo é necessária e autorizada - reconhecida como verdadeira. Para Ducrot (1987, p.32),

[...] o subentendido se caracteriza pelo fato de que, sendo observado em certos enunciados de uma frase, não está marcado na frase. Essa situação do subtendido se explica pelo processo interpretativo do qual ele provém. Para mim, com efeito, ele é sempre gerado como resposta a perguntas do tipo: "Por que o locutor disse o que disse?, "O que tornou possivel a sua fala?"

Diferentemente do pressuposto, o subtendido não está localizado no nivel da frase; portanto, é necessário um ouvinte, num momento posterior, refletir sobre o referido enunciado. (p.21). O enunciado subentendido diz que há uma lacuna entre o desenvolvimento dos estudos da linguagem e os seus processos de ensino; que a educação, tanto de um lugar de saber como de um lugar de poder, não tem lidado adequadamente com a linguagem do/no mundo contemporâneo, com a sua diversidade, seja no que se refere às suas concepções, seja no que se refere às suas manifestações; e que há algo que regula essa (in)adequação. 
A descrição do processo enunciativo ${ }^{26}$ coloca-nos diante da presença de figuras enunciativas que são identificadas como o locutor, aquele que produz as palavras no momento da enunciação e por elas se responsabiliza e o enunciador, aquele a quem é atribuida a responsabilidade dos atos ilocutórios veiculados pelo enunciado do locutor. Considerando que todo dizer tem uma força ilocucionária, ou seja, pretende provocar uma ação sobre o outro, os enunciadores foram construídos a partir das ordens apresentadas: - Quem fala do lugar da definição dos objetivos, quem fala do lugar da especificação do objeto e quem fala do lugar da orientação do objeto?

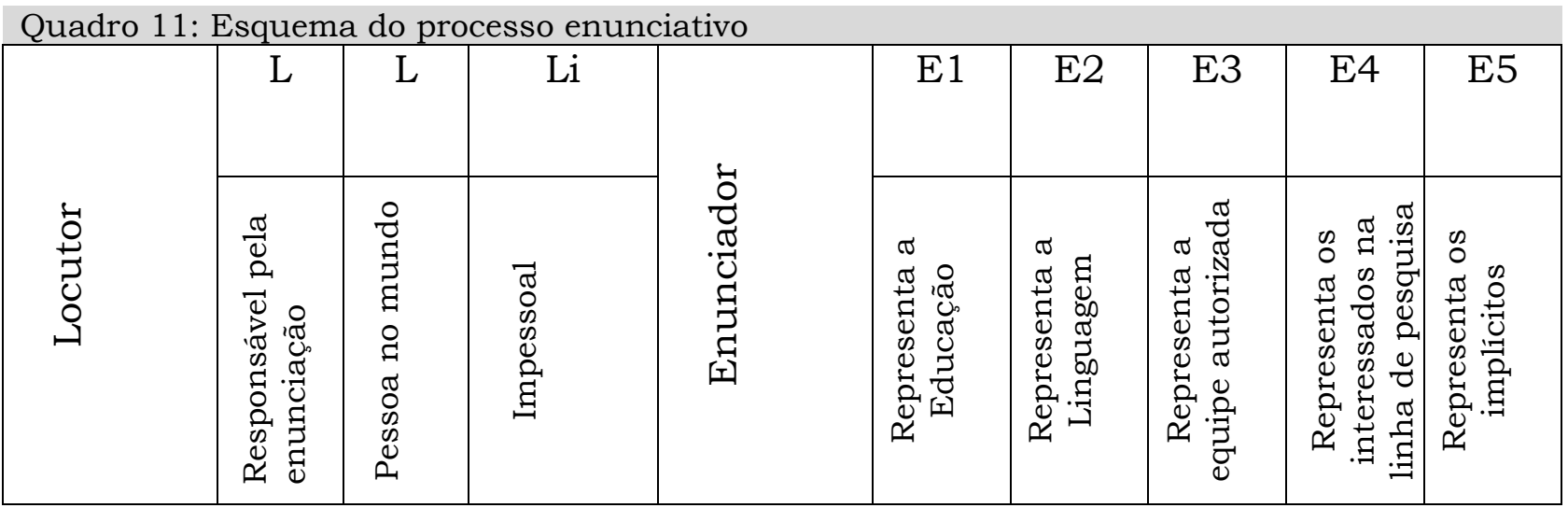

De maneira geral, o responsável pela enunciação (L) é a equipe de que produz as ementas, professores e pesquisadores que trabalham em nome da universidade a qual estão vinculados. É raro, nesse contexto, que haja uma representação do 1, que representa a pessoa no mundo, individualizada. O locutor manifesto em maior frequência é o $\mathrm{Li}$, dada a própria natureza das ementas. Embora a impessoalidade e objetividade do gênero, há marcas de subjetividade e, portanto, presença de enunciadores $(\mathrm{E})$.

O E1 representa a instituição, o órgão oficial, que se inscreve no discurso para agregar-lhe autoridade e cedê-la, quando necessário, à Linguagem ou à Educação. O E2 representa a Educação - pessoas ligadas a

26 Tomo como modelo a análise realizada por Indursky (2007) do Relatório Pinotti, com base na Teoria Polifônica da Enunciação, de Ducrot (1987). 
essa área, conhecidas como generalistas; alguém que conhece o ambiente e, não necessariamente, o objeto. O E3 representa a Linguagem - pessoas ligadas a essa área, conhecidas como especialistas; alguém que conhece o ambiente, mas, sobretudo, o objeto. O E4 representa os interessados em participar da linhas de pesquisa: professores, pesquisadores e alunos, que podem estar ou não diretamente ligados a uma das duas áreas ou às duas. Finalmente, o E5 representa os enunciados que estão implícitos naqueles produzidos por E1, E2, E3 e E4.

$\mathrm{Na}$ ordem da definição dos objetivos, o locutor (L) abriga E1, que assume, nesse momento, o lugar de poder para apresentar a E4 os interesses das linhas de pesquisa, quais sejam desenvolver/realizar estudos/pesquisas na área da Linguagem, voltada para o ambiente da educação. Para participar da linha de pesquisa, E4 deve aceitar o lugar de saber de onde E1 fala e, por consequência, os limites que lhes são apresentadas.

Delimitação também é o que aparece na segunda ordem, a da especificação do objeto. E3 assume o lugar de saber para dizer que, na linha de pesquisa, linguagem abarca a língua, as suas modalidades (oral, escrita), as suas manifestações (culturais) e os seus usos (na comunicação e em processos de interação).

Da ordem da orientação do objeto, quem assume o lugar de saber é E2, mostrando que tudo o que envolve o ensino pode ser considerado ambiente de educação: processos (alfabetização, letramento, escrita), lugares físicos, formação de professores, aspectos (sociais, cognitivos, históricos). E5 se manifesta, sobreposto a E2 e a E3, na medida em que, embora nos lugares de saber, esses enunciadores sabem que não conseguem prever tudo o que possa estar nas dimensões da linguagem e da educação. No enunciado, E5 não raro está marcado por pró-formas como múltiplos, diversos, diferentes, outros, vários, questões. 
Por se tratar de ementas, não há um a quem que se possa atribuir, diretamente e individualmente, uma autoria. Por isso, não se pode identificar a representação de 1 , a não ser pelas especificidades do objeto e/ou dos ambientes de educação. Há marcas de um ser-no-mundo que parece "cavar", de última hora, sua inserção no enunciado: o cinema, a arte, (em outras ementas que não as cinco do Quadro 12) a matemática.

O locutor predominante nas ementas é Li, o locutor impessoal, que aparece nas três ordens, associado a E2 e a E3. A associação entre Li e E1 representa o discurso produzido do lugar do poder: as instituições, dentre as quais a própria linha de pesquisa torna inquestionáveis as regulamentações e estabelecer os termos do alcance da linha de pesquisa.

Em sintese, a equipe responsável pela escrita das ementas e que, portanto, conhece todo o seu conteúdo, está aqui representada pelo Enunciador13 (E1), que assume uma posição de saber e de poder diante do destinatário. O Enunciador 4 (E4) não é sujeito do saber, apenas do poder, na medida em que, aparentemente, ele escolhe participar ou não da linha de pesquisa. Os Enunciadores 2 e 3 (E2 e E3) representam as diferenças na equipe de elaboração que, de um lugar de saber, intervém nas escolhas do destinatário assumindo uma posição de poder, fisgando-o na teia que vai convencê-lo de suas afinidades com a linha de pesquisa ou dissuadi-lo de sua participação nela.

No jogo polifônico, há sobreposição das seguintes figuras enunciativas:

a) L, E1, E4 - o responsável pela enunciação é a equipe de elaboração das ementas, que se dirige aos interessados em fazerem parte da linha de pesquisa; b) L, E1, E2, E3, E4, E5 - o responsável pela enunciação é a equipe técnica, dentro da qual se destaca a voz do especialista e dos implícitos que subjazem à fala desses dois enunciadores, dirigindo-se aos interessados na linha de pesquisa; c) 1, E1, E2, E3, E4, E5 - a pessoa no mundo que assume a 
enunciação e em cuja fala se subtende uma cumplicidade forjada com "um interessado específico"; d) Li, E1, E4 - o locutor impessoal é o poder, os órgãos oficiais do Governo que se camuflam em equipe de elaboração e se dirigem aos interessados; e) L, E2, E3 e E4 - o responsável pela enunciação cria uma ambiguidade entre o discurso da equipe de elaboração e o de cada uma das áreas, para dirigir-se aos interessados dos lugares de saber e de poder.

Esse jogo polifônico é resultado da rede de vozes que se articulam na produção do sentido - os gritos dos galos tecendo a manhã.

As ementas manifestam uma feição polifônica e polieidética, na medida em que há confluência de vozes - os enunciadores - e de imagens que emergem de um mesmo enunciador e/ou de um mesmo sujeito. Esses sujeitos falam de um lugar de poder e/ou de um lugar de saber e embaçam as vozes que do texto emergem: quem fala o quê para quem e para quê? O desembaçamento dessas vozes requereu a delineação de imagens projetadas pelo e no discurso. Necessário, também, um afastamento da ilusão da transparência do posto para desmascarar o pressuposto e o subtendido, atestando a opacidade da linguagem.

\subsection{AS IMAGENS DAS MIÇANGAS}

O sujeito não é a fonte do sentido. O lugar que ele ocupa na sociedade (lugar social) é que é determinante para a construção do seu lugar discursivo e, portanto, do seu discurso. Dos lugares que ocupam, as imagens que os interlocutores constroem de si e do outro (as formações imaginárias) acontecem no interior de uma formação social, e são determinadas por lugares empíricos (institucionais). Desses lugares as imagens da Educação e da Linguagem foram forjadas como ambiente e objeto, no diálogo. 
Para Pêcheux (1995, p.102), a formação social é constituída pelas posições políticas e ideológicas que não são obra de indivíduos, mas se organizam em formações, mantendo entre si relações de antagonismo, de aliança ou de domínio. Então, a equipe responsável pela produção das ementas e os pesquisadores que procuram desenvolver seus trabalhos nas linhas de pesquisa que descrevem assumem posições estruturalmente antagônicas, enquanto enunciadores, conquanto, politicamente, apresentem-se como aliados, na medida em que mantêm a ordem do discurso sobre a educação, assegurando a conservação dos discursos que devem circular nas instituições de ensino, segundo regras de exclusão dissimuladas em princípios.

De fato, embora, em posições antagônicas, esses enunciadores devem endossar (ou adoçar) o discurso oficial, o que se dá pela introjeção do discurso produzido de um lugar de poder, ocupado por aquele. Por sua vez, o Governo, do lugar de poder que ocupa, promove o controle dos discursos produzidos, estabelecendo as condições de sua produção - o que, onde e como pode ser dito - na medida em que interdita alguns para e a partir do estímulo de outros (discursos).

Olhando para os interlocutores que se manifestam na produção das ementas aqui analisadas (R), acolhe-se o esquema das expressões que designam as formações imaginárias, proposto por Pêcheux (2010), no qual o sujeito A estará relacionado ao enunciador E2 e o sujeito B estará relacionado ao enunciador E3, apresentados anteriormente:

\begin{tabular}{|c|c|c|}
\hline $\begin{array}{l}\text { Expressões que designam as } \\
\text { formações imaginárias }\end{array}$ & $\begin{array}{l}\text { Significação da } \\
\text { expressão }\end{array}$ & $\begin{array}{l}\text { Questão implícita cuja "resposta" } \\
\text { subtende a formação imaginária } \\
\text { correspondente }\end{array}$ \\
\hline $\mathrm{I}_{\mathrm{A}}(\mathrm{R})$ & $\begin{array}{c}\text { "Ponto de vista" de } \\
\text { A sobre R }\end{array}$ & "De que lhe falo assim?" \\
\hline $\mathrm{I}_{\mathrm{B}}(\mathrm{R})$ & $\begin{array}{c}\text { "Ponto de vista" de } \\
\text { B sobre R }\end{array}$ & "De que ele me fala assim?" \\
\hline
\end{tabular}




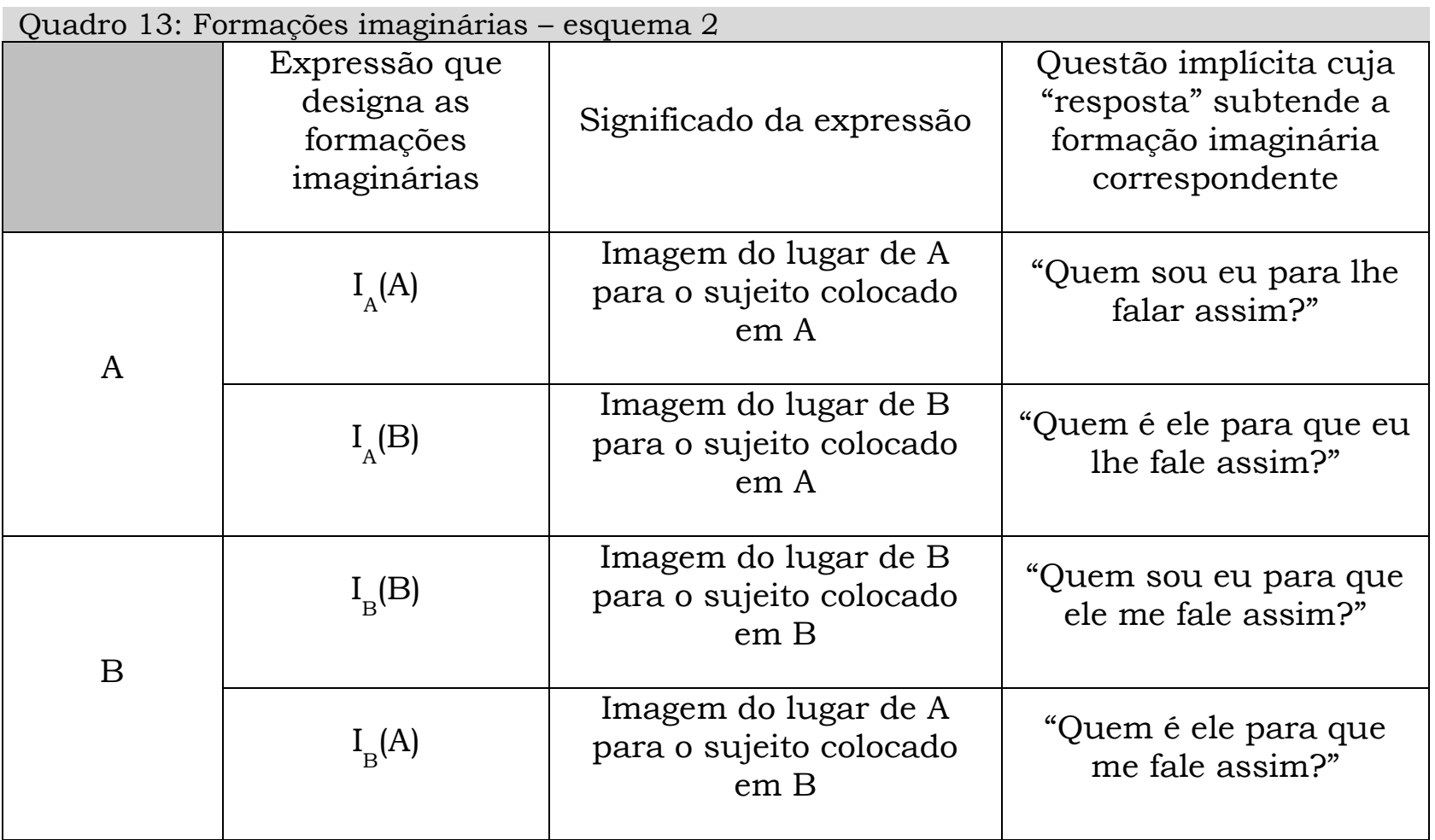

As ementas do Quadro 12 são produzidas em programas de pós em Educação. Nesse ambiente conhecido, a Educação está enfatizada nos seus espaços formais, institucionais, mas, implicitamente, aqueles possiveis também podem ser contemplados ("contextos educativos diversos"). É uma forma de (a linha de pesquisa ou a instituição) não se comprometer com uma visão mais estreita de educação, na qual o papel da escola, em seus moldes tradicionais, fica menos importante. Sem afirmar que a educação só pode acontecer em ambientes formais, não explicita qualquer compromisso com os estudos e as pesquisas realizadas em ambientes informais de educação. A Educação que interessa à pesquisa é a educação institucionalizada e, nesse ambiente, os processos têm privilégios sobre os conteúdos $\left(\mathrm{I}_{\mathrm{A}}(\mathrm{R})\right)$. É a base, o fundamento e a fundamentação técnica e filosófica sob a qual a Linguagem, um de seus objetos, um dos reflexos de um grande prisma $\left(\mathrm{I}_{A}(\mathrm{~B})\right)$, é tratada $\left(\mathrm{I}_{A}(\mathrm{~A})\right)$. 
O lugar da Linguagem, nas ementas, é distintamente marcado em E18, na qual a abrangência enunciada do termo é maior (literatura, arte). Nas demais, é, sobretudo, a língua portuguesa, língua materna, um componente curricular cujos conteúdos são hierarquizados em níveis e em modalidades (IB $(\mathrm{R}))$. É um objeto amplo, complexo, múltiplo e variado, sobre o qual se devem debruçar generalistas e especialistas $\left(\mathrm{I}_{\mathrm{B}}(\mathrm{B})\right)$. Tão heterogêneo, variado, abrangente e intrigante é esse objeto, que há uma fragilidade na formação dos profissionais que lidam com ele, nas escolas; daí a necessidade de a Educação se voltar para o seu ensino, seja no nivel de aquisição da escrita, na fase de alfabetização e letramento, seja em níveis diversos de seu desenvolvimento. “A Linguagem merece que a Educação lute por ela 27 ". ( $\left.I_{B}(A)\right)$.

Ora, alguém organiza o diálogo e, ao fazer essa organização, é muitas vezes compelido a seguir determinadas exigências, para que, ao final, o colar sirva a alguém: pelas nuances, formatos e tamanho das miçangas. Ele trabalha pelo critério de aceitabilidade. Essa aceitabilidade é discursiva e determinante das condições de produção de um colar, atravessado pelo ensino: um fio que atravessa discursos, miçangas materializadas pelos dados desta minha procura de encontrar os determinantes do ensino: o fio do colar.

27 Alusão à citação de Foucault (), referendada na página desta tese 


\section{O FIO QUASE INVISÍVEL EM COLAR VISTOSO}

A miçanga, todos a veem. Ninguém nota o fio que, em colar vistoso, vai compondo as miçangas.

(COUTO, 2009, p.3)

Os galos tecem a manhã com suas vozes, que se cruzam trazendo a luz ao dia; antes havia o silêncio, a noite, a escuridão. O silêncio importa às vozes como a luz importa às miçangas, e as miçangas ao fio, para ser colar.

Há uma sinestesia entre luz e som naquilo que o filósofo argentino Santiago Kovadloff (2003) chama de silêncio da luz, para tratar do jogo de luz e sombras que caracteriza as obras do pintor holandês Johannes Vermeer (1632). Em sua análise, a composição é o abrigo de uma expressão velada do pensamento, tornando visivel, pela luz, partes da obra (composta, em sua maioria, de cenas simples da vida cotidiana) que deseja destacar. Esse maestria peculiar forja o artista como intérprete e restabelece o objeto como matéria de interpretação e não de reprodução - um fluxo de movimento que se aspira a transluzir como a verdade que não se pode capturar: "Pintar para que o invisivel permita que as suas impressões sejam sentidas no visivel” (p.132).

A luz, na Física, reflete e atravessa o objeto que visualmente cria, em sensação. Em demasia, ao invés de expandir a extremos a visão, conduz a seu inverso. Na Metafísica, nos dois extremos do não ver, não está a inexistência; antes o seu contrário, legitimado pelo intervalo entre a latência e o evento. Essa abstração justifica a metáfora: conferir cor ao invisivel, trazer à tona o que se esconde, ver o sentido do que parece ter se esvanecido por entre miçangas, vozes, temas, ementas e linha. Tratar o abstrato de forma concreta como conceito, sem reduzir ensino a aula, como tradicionalmente parece que acontece. Por isso não fiz o percurso pela aula, mas pelos determinantes do fio. 
O ensino - seja em seus processos, seja na formação de professores assim como nos quadros de Vermeer, é um elemento, no jogo que articula Linguagem e Educação, que aparece bastante "iluminado", tanto nas ementas das linhas de pesquisa, quanto em seus nomes. E, da mesma forma que, na Física, o excesso de luz provoca uma espécie de cegueira, não se consegue ver bem, do seu desenho, senão os contornos. O destaque dado ao ensino pela sua recorrência, paradoxalmente, o coloca em uma posição de centralidade na articulação, mas indica, também, a necessidade de pesquisas sobre ele.

\begin{tabular}{|c|c|c|}
\hline E1 & - & $\begin{array}{l}\text { Estudo da linguagem em suas múltiplas dimensões, em } \\
\text { contextos educativos diversos e em diferentes niveis de } \\
\text { escolarização, visando à compreensão dos processos de ensino } \\
\text { e aprendizagem fundados em quatro pontos essenciais. }\end{array}$ \\
\hline $\mathrm{E} 2$ & - & $\begin{array}{l}\text { Estuda questões relacionadas com o processo de ensino- } \\
\text { aprendizagem das linguagens oral, escrita, visual e } \\
\text { matemática na educação formal e não formal. }\end{array}$ \\
\hline E3 & - & $\begin{array}{l}\text { Aspectos cognitivos, sociais e históricos das práticas } \\
\text { linguísticas, lingua portuguesa na aprendizagem escolar; } \\
\text { linguagem verbal e outras linguagens; cultura escrita, } \\
\text { alfabetização e letramento; ensino de literatura; oralidade e } \\
\text { escrita. }\end{array}$ \\
\hline E5 & - & $\begin{array}{l}\text { Investiga as relações entre linguagem, cultura e cognição } \\
\text { focalizando a linguagem em suas diferentes perspectivas. } \\
\text { Aborda também a construção do conhecimento, o ensino } \\
\text { aprendizagem, a leitura e a escrita e a formação de } \\
\text { professores. }\end{array}$ \\
\hline E6 & - & $\begin{array}{l}\text { A Ciência da linguagem é o objeto de estudo desta linha, com } \\
\text { ênfase nos estudos literários, do texto e ensino de línguas, } \\
\text { levando-se em consideração as práticas sociais, as diversas } \\
\text { modalidades linguísticas, os diversos gêneros textuais, entre } \\
\text { outras. }\end{array}$ \\
\hline E9 & - & $\begin{array}{l}\text { Desenvolve pesquisas acerca de várias temáticas ligada ao } \\
\text { ensino e aprendizagem da lingua portuguesa: práticas de } \\
\text { alfabetização e letramento; formação de professores, avaliação } \\
\text { educacional; propostas curriculares; entre outras. }\end{array}$ \\
\hline E18 & - & $\begin{array}{l}\text { Desenvolve estudos de linguagem e de literatura, focalizando } \\
\text { questões de ensino e de aprendizagem, bem como estudos } \\
\text { referentes à arte e à comunicação em suas múltiplas relações }\end{array}$ \\
\hline
\end{tabular}




\begin{tabular}{|c|c|c|}
\hline & & com a escola. \\
\hline E19 & $\begin{array}{ll}\text { Abordagens } & \\
\text { pedagógicas } & \text { do } \\
\text { ensino } & \text { de } \\
\text { linguagem } & \end{array}$ & - \\
\hline E20 & $\begin{array}{l}\text { Linguística } \\
\text { aplicada: } \\
\text { ensino e } \\
\text { aprendizagem } \\
\text { de lingua } \\
\text { materna e } \\
\text { estrangeira }\end{array}$ & $\begin{array}{l}\text { Estudo de questões teóricas e empíricas sobre o ensino e } \\
\text { aprendizagem de língua materna e estrangeira dentro de uma } \\
\text { perspectiva discursiva e sócio-cultural com foco em: formação } \\
\text { de professores, crenças/representações sociais de professores } \\
\text { e alunos. }\end{array}$ \\
\hline E21 & $\begin{array}{ll}\text { Ensino } & \text { de } \\
\text { linguagens }\end{array}$ & $\begin{array}{l}\text { Promover a discussão de questões relacionadas ao ensino de } \\
\text { Língua e literatura articuladas com as diferentes formas de } \\
\text { linguagens. A ideia central é propiciar mecanismos de reflexão } \\
\text { sobre as práticas de ensino de linguagens. }\end{array}$ \\
\hline E22 & $\begin{array}{ll}\text { Análise } & \text { de } \\
\text { práticas } & \text { de } \\
\text { linguagem } & \text { no } \\
\text { campo } & \text { do } \\
\text { ensino } & \end{array}$ & - \\
\hline E23 & $\begin{array}{l}\text { Ensino- } \\
\text { aprendizagem } \\
\text { de linguas }\end{array}$ & $\begin{array}{l}\text { Objetiva-se a realização de pesquisas que enfoquem aspectos } \\
\text { de ensino e aprendizagem de línguas. }\end{array}$ \\
\hline E24 & $\begin{array}{l}\text { Ensino da } \\
\text { lingua } \\
\text { portuguesa: } \\
\text { história, } \\
\text { politicas, } \\
\text { sentido social, } \\
\text { metodologias e } \\
\text { pesquisa }\end{array}$ & $\begin{array}{l}\text { Abordagem dos principais problemas referentes ao ensino da } \\
\text { LP, tendo em vista sua complexidade e dimensão: aspectos } \\
\text { gramaticais e lingüísticos, perspectivas estilisticas e } \\
\text { semióticas, bem como as questões de leitura, livro didático e } \\
\text { produção de textos. }\end{array}$ \\
\hline E25 & $\begin{array}{l}\text { Ensino } \mathrm{e} \\
\text { aprendizagem } \\
\text { de línguas }\end{array}$ & $\begin{array}{l}\text { Com base em estudos de Linguística Aplicada, esta linha de } \\
\text { pesquisa pretende reunir e estimular projetos voltados para } \\
\text { processos de ensino e aprendizagem de linguas materna e } \\
\text { estrangeiras. }\end{array}$ \\
\hline E26 & $\begin{array}{lr}\text { Ensino } & \text { de } \\
\text { linguas } & \mathrm{e} \\
\text { literaturas } & \end{array}$ & $\begin{array}{l}\text { Estudos sobre o ensino-aprendizagem de línguas e de suas } \\
\text { respectivas literaturas. }\end{array}$ \\
\hline E27 & $\begin{array}{lr}\text { Lingua } & \mathrm{e} \\
\text { interação } & \mathrm{em} \\
\end{array}$ & $\begin{array}{l}\text { Linha de reflexão com dois eixos temáticos: } 1 \text {. língua(gem) no } \\
\text { contexto das práticas sociais contemporâneas; } 2 \text {. formação de }\end{array}$ \\
\hline
\end{tabular}




\begin{tabular}{|c|c|c|}
\hline & $\begin{array}{l}\text { contexto } \\
\text { ensino }\end{array}$ & $\begin{array}{l}\text { professor, focando a construção de saberes e de objeto de } \\
\text { ensino. }\end{array}$ \\
\hline E28 & $\begin{array}{lr}\text { Lingua(gem) } & \text { em } \\
\text { contexto } & \text { de } \\
\text { ensino } & \text { de } \\
\text { português } & - \\
\text { lingua materna }\end{array}$ & $\begin{array}{l}\text { Estuda a língua(gem), focalizando a natureza e/ou a descrição } \\
\text { do fato lingüistico/discursivo no contexto das práticas sociais } \\
\text { e o o trabalho docente, focalizando a formação e a prática do } \\
\text { professor e a construção de objeto(s) de ensino e de } \\
\text { identidades. }\end{array}$ \\
\hline E29 & Lingua e ensino & $\begin{array}{l}\text { Exame das normas e registros que caracterizam o português } \\
\text { nos niveis semântico-lexical, fonético-fonológico, } \\
\text { morfossintático e textual, com vista ao seu ensino como lingua } \\
1 \text { e lingua } 2 \text {. }\end{array}$ \\
\hline E30 & $\begin{array}{l}\text { Linguagem, } \\
\text { tecnologia } \\
\text { ensino }\end{array}$ & $\begin{array}{l}\text { Estudos sobre multiletramentos e ensino de linguas, } \\
\text { abordando gêneros impressos e digitais; o texto em } \\
\text { diferentes perspectivas, contextos, modalidades e midias; } \\
\text { o trabalho docente e os recursos instrucionais. }\end{array}$ \\
\hline E31 & $\begin{array}{l}\text { Linguagem } \\
\text { ensino }\end{array}$ & $\begin{array}{l}\text { Abrange uma multiplicidade de aspectos dos } \\
\text { estudos lingüisticos e literários voltados ao Ensino- } \\
\text { aprendizagem do Português como língua materna e como } \\
\text { língua estrangeira (PLE). Seu principal objetivo é formar } \\
\text { profissionais capazes de lidar com as linguagens, de } \\
\text { forma critica, reflexiva e ética, no âmbito do Ensino e da } \\
\text { pesquisa, conscientes de sua inserção na sociedade. }\end{array}$ \\
\hline
\end{tabular}

$\mathrm{Na}$ articulação entre Linguagem e Educação, a palavra ensino aparece em 13 nomes e em 18 ementas das 31 linhas de pesquisa, em composições como "estudo dos seus processos" (E1, E2, E5 e E18); "aprendizado de língua(s) e/ou literatura, leitura e escrita” (E3, E6, E9, E19, E20, E23, E24, E25, E26, E29, E30 e E31) e/ou parte da formação docente (E22, E27 e E28). Nas ementas em que ensino não aparece, ele está pressuposto nas expressões inovações pedagógicas, metodológicas e tecnológicas (E4); alfabetização e letramento (E7, E17); relações/processos educativos ou de escolarização/comunicação (E8, E10, E11, E13, E15); recepção (E12); aprendizagem (E13); ação pedagógica (E15) ou propostas pedagógicas em cenário de educação presencial (E16). 
Esse excesso de luz sobre o ensino nesse ambiente de articulação entre Linguagem e Educação é, certamente, parte da herança dos esforços da Linguística de dar, a essa ciência, tonalidades mais verde-amarelas e contra a acusação de ser a responsável pela deteriorização do ensino de língua materna. Essa "acusação" é consequência de um equívoco no que se refere às contribuições da Ciência da Linguagem ao ensino de Língua Portuguesa: o de que ela ia de encontro à tradição gramatical na qual o ensino se pautava, sem, contudo, oferecer, a essa tradição, uma alternativa.

De fato, de acordo com Altman (1998), Castilho (1965), Soares (2002) e Pietri (2003), a assunção de um viés mais pragmático do ensino, fundamentado na Teoria da Comunicação, foi uma mudança promovida nos anos 60 e 70, sob os domínios do projeto de "democratização do ensino" do governo militar. Foi essa mudança que implementou o livro didático como "cartilha" a ser seguida pelos professores e, nele, o espaço da gramática tradicional e dos textos literários foi ocupado por esquemas de comunicação e por textos - e gêneros textuais - mais usuais, incluídos, aí, os textos não-verbais.

O desafio da Linguística no que se refere ao ensino de Língua Portuguesa - e esse desafio é assumido e espelhado na centralidade do ensino nas ementas - era (ou é) diminuir a distância entre a tradição do ensino gramatical, baseado nas normas de uma língua ideal, homogênea, literária e escrita, e a variação linguística, sem ser permissiva e levando o ensino da norma a todos.

O ensino, nessa posição de centralidade na articulação entre Linguagem e Educação e nesta tese, não é uma miçanga. É o fio que promove a articulação ao diálogo entre os determinantes discursivos, as miçangas. E é um fio que, assim como o colar, está sendo tecido, em fios e em vozes que se entrecruzaram, tecendo uma manhã de sexta-feira também: 
Caminho por aqui com a maior miçanga. Enquanto o fio atravessa Linguagem e Educação, há uma miçanga maior, transparente para muitos, que separa as grandes miçangas Linguagem e Educação. É a miçanga com efeito de discurso oficial, político.

Para isso lembro o segundo dia do novo ano. O dia que se seguiu àquele da posse da presidenta do Brasil, reeleita. Os telejornais, ainda ressacados dos especiais de final de ano, puseram em suas pautas pouca coisa além da divulgação de partes do evento do dia anterior, mostrando muitos flashes, militantes nos além-muros das solenidades e locais para os quais a limusine oficial se deslocava entre coquetéis e jantares e correligionários.

No cenário quase oscariano, chamava-se a atenção para a cor outra, diferente da esperada, na roupa escolhida pela personagem do dia. Essas pequenas atenções deslocavam o acontecimento da esfera política para a esfera social. Desse desacoplamento produzido pela mídia, fundava-se como lugar de acontecimento político não o evento em si, mas aquilo que dele foi filtrado pelas lentes dos comentaristas especializados.

Foi assim que um deles entrou em cena para glosar sobre o novo lema do novo governo da mesma presidenta, "Brasil, pátria educadora", fazendo-o pelo viés do equívoco, na medida em que explicava, com a entonação da autoridade constituída naquele lugar, para aquele público, naquele ambiente, que Educação é uma coisa e Ensino é outra:

A presidente indicou a Educação como a prioridade das prioridades. Lançou o lema que a gente ouviu há pouco, "Brasil, pátria educadora", e lembrou que Educação inclui formação de cidadania e de ética. Aí é bom que a gente lembre que formação e 
Educação são responsabilidades do pai e da mãe; ensinar princípios de ética, de cidadania e vida em coletividade. Ao setor público cabe o Ensino. Aí, é fácil de entender que o lema não promete que o Estado vá substituir os pais, porque, afinal, as palavras de ordem, vou lembrar, são: "Brasil, PÁTRIA educadora". Pátria é a nação, não é apenas o Estado. Pátria começa em casa. E chega bem o estímulo do Estado para lembrar para a família de suas responsabilidades. A família fazendo a sua parte exigirá que o Estado cumpra o seu papel, preparando professores de qualidade e oferecendo escolas acolhedoras, como templos do Ensino. (Transcrição minha. Disponivel em http://g1.globo.com/bom-dia-brasil/noticia/2015/01/botartranca-em-porta-arrombada-diz-alexandre-garcia-sobreposse.html. Acesso em 02/01/2015).

As nuances discursivas forjadas no linguístico, palavras como "lançar" um lema; expressões como "é fácil entender"; e leituras inusitadas como "o lema não promete que o Estado vá substituir os pais"; e a ironia com que a qualidade dos professores e o ambiente escolar, na atualidade ou na sua projeção futura, foram tratados atestam, no mínimo, a má vontade do comentarista, menos, talvez, com o próprio documento da Secretaria de Assuntos Estratégicos do Governo, do que com a nova vitória da Presidenta ${ }^{28}$.

Esse documento ${ }^{29}$, aliás, logo após a sua publicação em abril de 2015, mesmo em versão preliminar, gerou grande desconforto em vários setores da Educação no Brasil, começando pelas universidades públicas, para quem foi, primeiramente, encaminhado. De um lado porque as mudanças constantes na gestão da pasta ${ }^{30}$ e os cortes no orçamento, sobretudo em programas de incentivo como o FIES, o Ciências sem fronteiras e o PRONATEC, bem como o sucateamento das universidades, atestam a não priorização, pelo governo, da Educação, ao contrário do que prega o lema. De outro lado, o conteúdo mesmo da proposta, que define o "tipo de politica pública que será considerada válida e

28 Grande parcela da sociedade brasileira se sentiu incomodada com a vitória da candidata do PT, que ganhou as eleições em segundo turno, com 51,6\% dos votos válidos.

29 Intitulado "Pátria educadora: a qualificação do ensino básico como obra de construção nacional", constitui uma proposta para a criação de diretrizes de um projeto nacional de $\begin{array}{llll}\text { qualificação } & \text { do } & \text { ensino. } & \text { Disponível }\end{array}$ https://www.fe.unicamp.br/patriaeducadora/documento-sae.pdf

30 O governo da presidenta Dilma teve sete Ministros da Educação, seis deles diferentes (Aloízio Mercadante foi Ministro da Educação em dois momentos distintos desse governo). 
incentivada"31, constitui um desserviço aos avanços alcançados na Educação, na medida em que este se apoia em uma visão conservadora e mercadológica da Educação, se afastando tanto do Plano Nacional de Educação, aprovado em 2014, quanto das propostas das Conferências Nacionais de Educação, de um modo geral, em todos os quatro eixos (organização da cooperação federativa na educação; a reorientação do currículo e da maneira de ensinar e de aprender; a qualificação de diretores e de professores e o aproveitamento de novas tecnologias), em que as propostas estão organizadas:

O centro de tal política está na constituição de um núcleo fundamental baseado na definição de um currículo nacional ancorado em um forte sistema de avaliação nacional censitário, regado a responsabilização por mérito, com abertura da área educacional a Organizações Sociais e ao mercado empresarial. É uma política baseada em controle e pressão sobre as escolas e seu magistério, sendo uma propositura carente de base empírica que a recomende como política pública referendada em pesquisa. (In:"Carta Aberta”. Disponivel em: http://www.peticaopublica.com.br/pview.aspx?pi=BR82015)

"Formar o jovem para o mercado de trabalho" é uma visão bastante estreita do papel da Educação, e é uma perspectiva que tem crescido no Brasil, nos últimos 10 anos, incentivada pelo setor empresarial, desejoso que está de tornar o Brasil um país competitivo internacionalmente.

Há todo um vocabulário da empresa colando no discurso da Educação, que marca a politica empresarial: empreendendorismo, evidências, rentabilidade, pragmatismo, metas, produtividade, concorrência, desempenho, talentos, gestão... A eficiência está sempre relacionada ao baixo custo - uma condição para o sucesso no mercado. A substituição do ensino pela aplicação de avaliações é um exemplo prático dessa perspectiva, juntamente com a criação de projetos empresariais. Não pude deixar de lembrar uma campanha publicitária de uma das mais bem conceituadas escolas particulares na minha

\footnotetext{
${ }^{31}$ Ver a "Carta Aberta", produzida ao final de um ciclo de debates promovido pela Faculdade de Educação da UNICAMP, em maio de 2015, e do qual participaram 19 instituições de ensino em todo o país. Disponivel em: http://www.peticaopublica.com.br/pview.aspx?pi=BR82015
} 
cidade (de acordo com a colocação no ENEM), que foi veiculada em 2009, a título, também, de ilustração:

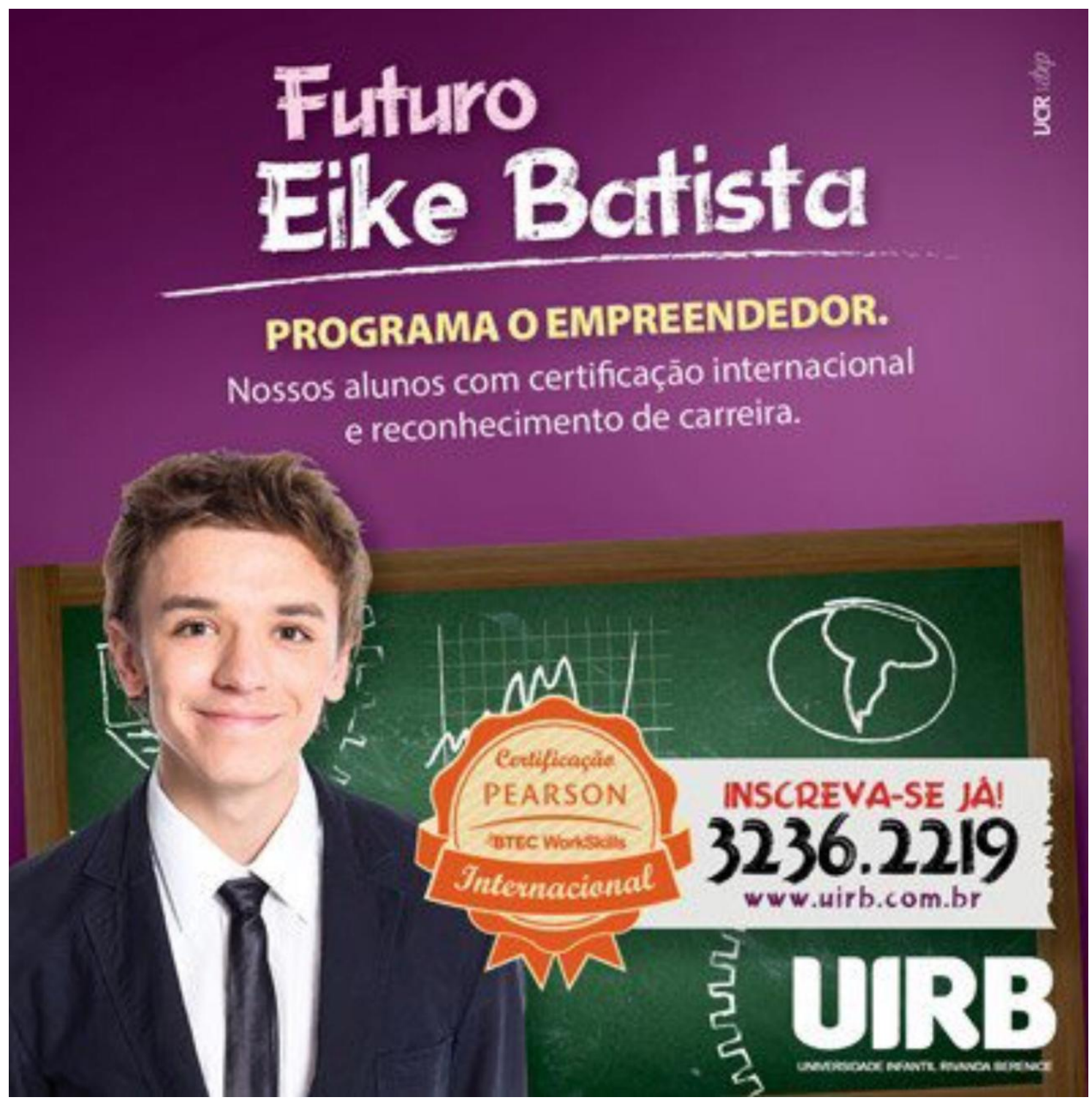

http://pt-br.facebook.com/curtauirb

A campanha da escola é fruto (apodrecido) de uma enorme desinformação, mas, também, de um projeto de Educação fundado, primeiro, sobre um grande equívoco do que seja sucesso - em termos de formação integral do ser humano -, e sobre o ideário de que o futuro é individual, personalizado e pode ser construído pelo empenho pessoal, que o sucesso 
depende exclusivamente do esforço e que este é atestado, em um certo momento, pelas notas nas avaliações a que se deve se submeter e, mais adiante, pelos bens materiais que se consegue acumular. Essa visão alija a formação humanizada, solidária e tolerante, capaz de integrar conhecimentos científicos e culturais e compreender o trabalho como uma forma de intervir positivamente na sociedade - essa, sim, a premissa da verdadeira Pátria Educadora, e que parece estar na pauta de investigação da maioria das ementas aqui analisadas.

A imagem do empresário, à época, bem sucedido, como, mais que um exemplo, um "nivel de excelência" "internacionalmente reconhecido", e que se deve desejar alcançar, atesta bem um modo de produção de opinião (e de parâmetros) de que Bourdieu fala (2015, p.391): um tipo de resposta plástica a um problema político complexo - a igualdade social - corrompido em ascensão econômica:

De fato, nem todas as respostas exprimem opiniões; [...] dissimula-se completamente o problema politico mais fundamental, ou seja, a questão dos modos de produção da resposta a uma questão política ao aceitar o postulado intelectualista que toda resposta a uma questão política é o produto de um ato de julgamento e de um ato de julgamento politico.

A imagem estampada em out-doors espalhados pela cidade representa um modelo de sucesso que transgride todas as representações da ética, oferecendo como "resposta" a "questões" inglórias relacionadas à educação padrões (da classe historicamente dominante) de etnia, roupa e penteado, que garantem o "selo de qualidade" e o sucesso.

Foi um parêntese longo para tratar brevemente de um assunto bastante complexo. 
Retomo a trama do fio e volto ao comentário do jornalista, mais especificamente à diferenciação assinalada, com ênfase, entre Educação e Ensino, e que pode e não estar nos seus usos, dos mais comuns aos mais especializados.

\subsection{O PRÓPRIO LUGAR}

Nos ambientes de linguagem ordinária, não é raro que o tratamento discursivo dispensado aos termos educação e ensino seja semelhante, no que se refere a seus fins: ser educado ou ensinado diz de comportamentos e valores em acordo com padrões sociais de uma comunidade: ser polido, urbano, culto, gentil e cortês; demonstrar boas maneiras na presença de outros e discorrer sobre a cultura32, demonstrando "traços do homem culto" (CERTEAU, 2003, p.193), isto é, asseverando o domínio e a reprodução do modelo que as classes dominantes reconhecem como necessário a um convívio ideal - sem “diferenças" ou conflitos.

O dicionário Aurélio (FERREIRA, 1999, p.766) define ensino como transmissão (de conhecimentos, informações etc.), como método e como esforço orientado para a formação; Travaglia (1996) fala de três tipos de ensino (para o ensino de lingua materna): o prescritivo, o descritivo e o produtivo33; Tonucci (2003), defendendo o Construtivismo, diferencia o ensino transmissivo do ensino construtivo. Há pelo menos duas formas de se entender o ensino: uma,

\footnotetext{
32 Uso um dos sentidos designados pelo termo apontado por Certeau (2003, p.194), que é a cultura como "comportamentos, instituições, ideologias e mitos que compõem quadros de referência e cujo conjunto, coerente ou não, caracteriza uma sociedade como diferente das outras."

${ }^{33}$ No ensino de língua, o ensino prescritivo é aquele que "prescreve" o que é certo e o que é errado, tendo como paradigma a variedade padrão da língua. O ensino descritivo é aquele pautado na descrição do funcionamento da língua, já adquirida e independente da modalidade utilizada pelo falante. O ensino produtivo é aquele centralizado na interação, então, todas as variedades são bem vindas e essenciais.
} 
que é a transmissão do conhecimento; a outra, que é a construção (ou produção) do conhecimento. Em uma concepção, há uma atividade centralizada no que (supõe que) sabe alguma coisa que interessa a outros; na outra, a centralidade da atividade se desloca para o que (alguém supõe que) não sabe alguma coisa que precisa saber.

Em ambas as concepções, o ensino é um resultado, que é a instrução. Institucionalizando esse resultado, ele precisa ser medido e classificado: excelente, bom, regular, insuficiente. É nessa esfera em que o ensino se confunde com a Educação e ambos com instrução e com comportamento, algo palpável e palatável.

Também em discursos mais especializados, pode-se encontrar tratamento semelhante no que se refere ao processo: educar e ensinar são ações que orientam para uma transformação de conduta, com vistas à integração individual e social, e nunca totalmente arrematadas. Como ação, há o pressuposto de sujeitos por ela afetados: em um pólo funcional, aquele que educa ou ensina; no outro, aquele para quem essa ação aponta, o educado ou o ensinado.

No documento "Pátria educadora: a qualificação do ensino básico como obra de construção nacional", por exemplo, a palavra “educação" aparece 32 vezes, para se referir a paradigma (modelo, campo) ou a setor de politica pública (ministério, secretarias, sistemas, esfera etc). Já a palavra "ensino" aparece 83 vezes: como escola (acesso ao ensino), como esfera (público, privado), como nível (básico, médio, técnico, superior), como modalidade (presencial, por vídeo), como tipo (geral, vocacional, prático, analítico, cooperativo) e como entidade abstrata: “o ensino".

Pela forma como aparecem nas ementas das linhas de pesquisa, o estudo e a investigação sobre o ensino parece estar mais delineado na defesa de uma concepção voltada para um processo de interação: “aspectos cognitivos, 
sociais e históricos das práticas linguísticas" (E3), "relações entre linguagem, cultura e cognição" (E5); "levando-se em consideração as práticas sociais" (E6), "dimensões que abrangem as relações da criança consigo, com outros e com o mundo" (E7), "abordagens sociológicas, psicológicas, históricas e linguísticas" (E8), "dentro de uma perspectiva discursiva e sócio-cultural" (E20), e "no contexto das práticas sociais" (E28).

A própria ideia de ensino como um processo (Quadro 9) ratifica o fundamento deste na interação. Tem menor representatividade, na coleção, a concepção de um ensino transmissivo, cujo conteúdo transmitido possa ser verificado. Essa tendência tem mais ênfase quando se trata de aquisição (da linguagem escrita, na alfabetização ou letramento, ou de línguas estrangeiras) e, mais raramente, de descrição de níveis de organização da língua (E3, E6, E9, E19, E20, E23, E24, E25, E26, E29, E30 e E31). Ainda assim, mesmo havendo um conteúdo a ser transmitido e verificado, há uma grande preocupação com a formação do professor, com a prática docente e com a construção de objeto(s) de ensino - como o professor pode ensinar o aluno, seja na perspectiva de transmitir o que sabe ou supõe saber, seja na perspectiva de orientar o aluno a construir o que o professor ou a comunidade (escolar ou de um modo geral) supõe que ele não saiba e precisa aprender para o melhor convívio ou desempenho na sociedade.

Há um movimento de meio (processo) para fim (aprendizagem), presente, mais explicitamente, em E1, E2, E5, E9, E12, E18, E20, E23, E25, E26 e E31. A interrogação está, eu creio, na comprovação dessa aprendizagem, o que acaba colocando em xeque o ensino, produzindo outro movimento - um movimento de culpa (do professor, do aluno, da sociedade, da família, da (in)disciplina, do Estado, dos recursos etc.., etc.., etc..), desprovido(a) de responsabilidades. Esse é um lugar de silenciamento, nas propostas das linhas de pesquisa. 
As ementas propõem olhar para o ensino como processo e para o processo de ensino, em 7 delas. Nessas, o interesse central parece ser na forma como se constrói um conhecimento sobre construir conhecimento, apontando para uma função metalinguística do ato de ensinar. Nas 13 outras, a palavra "processo" também aparece associada a ensino, mas o interesse central é deslocado do processo para um objeto específico: ensino da escrita; ensino da literatura; ensino de língua estrangeira; ensino de gramática. São objetos que supõem um conhecimento, de um lado, um não conhecimento, de outro, e uma transmissão, no meio. No entanto, essa suposta divisão não é suficiente para dizer do tipo de ensino.

Há um movimento em espiral que caracteriza o ensino, que o define; um movimento de ação e reação; de ponto bordado no pano ou de laçada que compõe miçangas em colar: uma trama, uma dança. Um movimento que resulta no próprio movimento (por isso sempre em espiral), aperfeiçoado e reinventado pela habilidade, pela técnica, pela disposição, pela cumplicidade. Há sempre algo que se estabiliza no movimento: um ponto, um nó - aquilo que fica de tudo o que se esquece 34

A etimologia mostra que as duas palavras nasceram no mesmo lugar, na mesma língua: o latim vulgar - o ordinário. E, no berço, começam a se delinear as particularidades. Vêm de ex-ducere (conduzir, levar) e de in-signare (indicar, marcar com um sinal).

Olhando não para o sentido das palavras, mas para as suas arquiteturas, para os prefixos ${ }^{35}$ que ajudaram a compô-las, em suas origens, percebe-se que há indício da ideia de movimento, de construção de uma trajetória: e(x)ducar seria, assim, um movimento para fora; e(i)nsinar, para

\footnotetext{
34 Tomei aqui emprestada a definição de cultura de Tristão de Athayde (Bloch, 1989). O ensino, como resultado de um movimento é, de fato, cultura.

35 Esses prefixos foram incorporados à palavra, mas são tomados, aqui, como um resíduo, ainda que marginal e trivial, considerado revelador. (Ginzburg, 1989, p.149-150).
} 
dentro. Atento a esse detalhe, a educação se manifesta do sujeito para fora dele; o ensino, da exterioridade do sujeito para o seu interior.

O educado diz de si, exterioriza o que tem de seu. Já no insinado, se vê, sobretudo, a marca daquilo que estava do lado de fora e foi apreendido. Um olhar mais atento consegue ver no ensinado uma insígnia do Outro (que o ensinou) ou de outro lugar. Do educado, o que se vê é ele mesmo. Do ensinado, sua alteridade.

Nessa relação entre os sujeitos constituídos em uma sintaxe espacial (CERTEAU, 2014, p.182), por meio de uma ação, a educação se materializa na esfera subjetiva do para quem ela se dirige, enquanto que o ensino se objetiviza na esfera de quem o produz-para-quem; a educação está situada no espaço da legenda, um espaço presente e presentificado (ser educado), enquanto que o ensino se localiza em um espaço de memória, que está presente em sua ausência (ter sido ensinado); aquilo a que só se tem acesso pelos seus efeitos.

Nas construções negativas, esses pequenos acidentes linguísticogeográficos, pormenores da linguagem, também podem ser sentidos: o homem comum, ao dizer "eu não fui educado" para alguma coisa, fala de um comportamento, de um hábito que não é seu, que ele não identifica como próprio e que, portanto, não pode exteriorizar, colocar para fora. Ao dizer do ensino, aponta para o outro: "ninguém me ensinou” isso ou dessa maneira, ou seja, essa informação ou instrução não foi apresentada (por outro) para si, para que fosse apreendida.

Há um espaço comum no lugar-comum do uso ordinário de educação, de ensino e de suas flexões, assim como há singularidades nos seus usos que vão dando nuances às identidades, fazendo com que, no mesmo espaço, não ocupem o mesmo lugar ${ }^{36}$. Essa impossibilidade de ocupar o mesmo lugar, no

36 Uso a distinção de Certeau entre espaço e lugar: enquanto o espaço se define pela "instabilidade" gerada pelo "cruzamento de móveis" que o caracteriza, o lugar é a estabilidade e 
diálogo entre Linguagem e Educação ou Linguagem e Ensino proposto pelos nomes das Linhas de Pesquisa, seria apenas uma lei da sintaxe ${ }^{37}$ ? (Quadro 15)

\begin{tabular}{|c|c|c|}
\hline \multicolumn{3}{|c|}{ Quadro 15: Educação e ensino } \\
\hline E9 & $\begin{array}{l}\text { EDUCAÇÃO } \\
\text { LINGUAGEM }\end{array}$ & $\begin{array}{l}\text { Desenvolve pesquisas acerca de várias temáticas ligada ao } \\
\text { ensino e aprendizagem da lingua portuguesa: práticas de } \\
\text { alfabetização e letramento; formação de professores, avaliação } \\
\text { educacional; propostas curriculares; entre outras. }\end{array}$ \\
\hline E18 & $\begin{array}{l}\text { LINGUAGEM E } \\
\text { EDUCAÇÃO }\end{array}$ & $\begin{array}{l}\text { Desenvolve estudos de linguagem e de literatura, focalizando } \\
\text { questões de ensino e de aprendizagem, bem como estudos } \\
\text { referentes à arte e à comunicação em suas múltiplas relações } \\
\text { com a escola. }\end{array}$ \\
\hline E31 & $\begin{array}{l}\text { LINGUAGEM E } \\
\text { ENSINO }\end{array}$ & $\begin{array}{l}\text { Abrange uma multiplicidade } \text { de aspectos } \\
\text { estudos lingüisticos e literários voltados ao Ensino- } \\
\text { aprendizagem do Português como lingua materna e como } \\
\text { lingua estrangeira (PLE). Seu principal objetivo é formar } \\
\text { profissionais capazes de lidar com as linguagens, de forma } \\
\text { crítica, reflexiva e ética, no âmbito do Ensino e da pesquisa, } \\
\text { conscientes de sua inserção na sociedade. }\end{array}$ \\
\hline
\end{tabular}

As ementas de E9 e E18 são "espelhadas", inclusive nos nomes: linguagem e educação / educação e linguagem. Reorganizei as duas, agora considerando o ano em que foram criadas (E18 em 1997 e E9 em 2002), em novo Quadro (Quadro 16) para visualizar melhor o espelhamento:

\begin{tabular}{|c|c|c|c|c|c|c|}
\hline \multicolumn{7}{|c|}{ o. Linguagem e Eauc } \\
\hline E18 & $\begin{array}{c}\text { Desenvolv } \\
\mathrm{e}\end{array}$ & Estudos & $\begin{array}{c}\text { Linguagem e } \\
\text { literatura }\end{array}$ & Questões & $\begin{array}{c}\text { Ensino e } \\
\text { aprendizagem }\end{array}$ & $\begin{array}{c}\text { Arte e } \\
\text { comunicaçã } \\
\text { o }\end{array}$ \\
\hline E9 & $\begin{array}{c}\text { Desenvolv } \\
\mathrm{e}\end{array}$ & $\begin{array}{c}\text { Pesquisa } \\
\mathrm{s}\end{array}$ & $\begin{array}{c}\text { Língua } \\
\text { portuguesa:: } \\
\text { práticas de }\end{array}$ & $\begin{array}{c}\text { Temática } \\
\text { s }\end{array}$ & $\begin{array}{c}\text { ensino e } \\
\text { aprendizagem } \\
\text {, formação de }\end{array}$ & - \\
\hline
\end{tabular}

a univocidade; "uma ordem segundo a qual se distribuem elementos nas relações de coexistência". (CERTEAU, 2014, p.184)

$37 \mathrm{Na}$ organização sintagmática da frase, apenas um elemento de um paradigma é escolhido para desempenhar uma função. Assim, para ocupar a função sintática de sujeito, por exemplo, é escolhido apenas um elemento do paradigma dos substantivos, ficando todos os outros substantivos excluídos, na organização da frase. Saussure (1995) apresenta o eixo paradigmático e o eixo sintagmático como uma das dicotomias da língua, enquanto sistema: o eixo das escolhas (uma linha vertical) e o eixo da organização (uma linha horizontal). 


\begin{tabular}{|l|l|l|l|l|l|}
\hline & & $\begin{array}{c}\text { alfabetizaçã } \\
\text { o e } \\
\text { letramento }\end{array}$ & & $\begin{array}{c}\text { professores, } \\
\text { avaliação } \\
\text { educacional, } \\
\text { propostas } \\
\text { curriculares }\end{array}$ & \\
\hline
\end{tabular}

Embora espelhadas, as concepções de linguagem que fundamentam uma e outra ementa estão postas: em E18, linguagem abarca as artes e a comunicação; em E9, é apenas a língua portuguesa. Trata-se, portanto, de uma linha de pesquisa sobre o ensino de lingua portuguesa e, apenas, no nível da escolarização. A indeterminação indiciada por "várias" e por "entre outras", no ambiente em que aparecem, não aponta para variedade, mas para uma indefinição mesmo. É o contrário do que acontece em E18, em que a vagueza de "questões" e "múltiplas" dá, às possibilidades de estudos. "Desenvolver pesquisas" e "desenvolver estudos" também corroboram esse viés mais “positivo" de E9 em relação a E18, embora, na aparência, possa ser o contrário, já que, para desenvolver uma pesquisa, há que haver estudo. A pesquisa é um caminho que leva a um resultado - não necessariamente positivo -, a partir da análise de dados; o estudo pressupõe chegar a um aprendizado que, mesmo sendo um tipo de resultado, em uma certa medida, é mais amplo.

Trata-se, portanto, em Educação e Linguagem, de pesquisas realizadas sobre o ensino e a aprendizagem - o foco é o processo; e em Linguagem e Educação, de estudos sobre a linguagem - o foco é o objeto. O foco altera a imagem, e essa alteração está dada no nome, nas posições que ocupam a linguagem e a educação.

Se E9 e E18 “desenvolver estudos" e "desenvolver pesquisas" funcionaram como lentes (diversas) para uma imagem espelhada, o que dizer de "abrange aspectos", em E31? Em relação à E9 tem um objeto ainda mais específico, dentro do que seja "ensino-aprendizagem do Português como língua materna ou estrangeira", embora não tenha nada especificado sobre que 
aspectos sejam esses. "Estudos linguísticos" é um indício, no entanto, dessa especificidade: a lingua. O plural "linguagens" que vem a seguir, no texto da ementa, refere-se, certamente, à língua portuguesa, seja como língua materna, seja como língua estrangeira. Da mesma forma "estudos literários", que participa como interesse constitutivo da ementa como um provável "aspecto" da língua portuguesa, não como uma linguagem - a linguagem literária como objeto de estudo ou de pesquisa.

Outro ponto que chama bastante atenção nessa ementa de uma linha de pesquisa de uma pós-graduação é que ensino e pesquisa são tomados como "âmbitos" distintos da formação profissional - seu principal objetivo, que seria o mesmo das licenciaturas. As palavras "crítica", "reflexiva" e "ética" e a expressão "conscientes de sua inserção na sociedade" fazem uma alusão aos Parâmetros Curriculares Nacionais (1997, p.33), cujo texto aponta como um dos objetivos do ensino de Língua Portuguesa “conhecer e analisar criticamente os usos da língua como veículo de valores e preconceitos de classe, credo, gênero ou etnia”, em conjuminância com o tema transversal Ética. Não diz, portanto, nada sobre um perfil de uma pesquisa (ou de estudos) sobre Linguagem e Educação; repete o que seriam objetivos de uma graduação, no que se refere ao ensino, e do ensino de Língua Portuguesa, no ciclo de educação básica, no que se refere ao conteúdo.

Em linhas de pesquisa, quando se fala em olhar para a dimensão do ensino, se pensa em um olhar filosófico para o seu alcance, para o seu valor. O aspecto está na aparência, naquilo que se mostra, de forma mais concreta. Tratam, pois, do que abrange o ensino da língua e de como é (ou deve ser) o seu ensino.

Essa diferença descreve uma lacuna entre a educação e ensino, e não uma complementaridade. O ensino aparece mais relacionado à sua acepção de instrução, de instrumentalização, de prática, de transmissão, e mais afastado de uma concepção de formação. 
Essa perspectiva, que diz respeito a espaço, também se manifesta no tratamento dado à formação de professores: na primeira ementa, a formação de professores é um objeto de estudo, dentre outros (arte, processos de comunicação social e tecnológica), enquanto que, na segunda, é o objetivo dos estudos. Essa diferença dá indícios de duas direções opostas na produção do conhecimento: uma orienta para uma produção epistêmica; a outra, para uma produção deôntica.

Mas "os jogos dos passos moldam os espaços. Tecem os lugares" (CERTEAU, 1985, p.163). Espacializadas no diálogo com a Linguagem, o ensino pode assumir um lugar próprio, distinto, diferenciado e singular, mas sempre contingente ao da Educação, pelo movimento que os andarilhos - professores e alunos - percorrem, pelos não lugares que atravessam e, assim, pensar o ensino não só como produção de um lugar, mas como lugar de produção. O ensino como lugar não apenas de transmissão, mas também de atravessamento, um seu avesso: o lugar de escuta e de transferência. O lugar onde o diálogo se superpõe à articulação.

O lugar de escuta é o lugar onde a voz da autoridade instituída silencia, no tempo em que o vazio será atravessado por um desejo do Outro de conquistar o que, também no Outro, é apenas suposto - o saber. Lacan (2010, p.330) diz que "o segredo que somos supostos deter é mais precioso do que tudo aquilo que se ignora e que se continuará a ignorar". A escuta é a reverberação, os efeitos do silêncio no movimento da atenção para dentro de si no in-sino.

Já a transferência (LACAN, 2010) se dá no jogo do eu-sinto-que-tu-tens e o eu-deixo-escondido-o-que-não-tenho e, te dando a falta, transfiro amor e ensino - como substantivo e como verbo. Nessa relação, há uma disparidade entre os sujeitos, em que um "não sabe" e supõe que o outro "saiba", tamponando, assim, sua falta. O lugar de Sujeito Suposto Saber é um efeito do 
discurso. Mesmo na dimensão mais prática do uso do colar, o fio se esconde sobre outras determinações específicas da Linguagem e da Educação.

Como efeito do discurso, a Linguagem escuta o ensino, e o ensino escuta a Educação e a Linguagem num sentido que ressoa no amarrar das miçangas.

\subsection{O NÃO-LUGAR}

Ocupada ainda em analisar o lugar da maior miçanga, o discurso político, volto ao episódio do comentário sobre o lema do governo para ver o equívoco, não no ponto em que ele foi mostrado, mas em outro, onde foi constituído. Educar é uma coisa. Ensinar é outra. Mas, no jogo da sintaxe, no espaço da linguagem, educar pode ser ensinar, e ensinar pode ser educar. Não porque sejam a mesma coisa, mas porque são peças de um jogo metonímico, no qual a Educação é o todo e o ensino, uma parte.

No lema escolhido, a "Pátria educadora" nem se exime de ensinar nem se abrevia ao ensino. Para além de oferecer o ensino, compromisso lembrado do setor público, a "Pátria educadora" abarca, não a substituição, mas o compartilhamento com a família (e com outras instituições que a integram) da responsabilidade com a construção do que é do coletivo, bem apontado pelo comentarista: os principios de ética e de cidadania. $\mathrm{Na}$ "Pátria educadora" estão conjugados, então, a Nação e o Estado; a Educação e o Ensino. Conjugados, não confundidos.

$\mathrm{Na}$ trama das intencionalidades, o equívoco mostrado não foi consequência de um desaviso nem uma distração; o comentarista não "mirou no que viu e acertou no que não viu". O que ele viu e mirou e acertou estrategicamente foi, sobretudo, o lugar de competência convertido em autoridade (CERTEAU, 2014, p.63), que lhe permitiu criar o que não precisou 
ver ou ouvir: "reconhecido como científico, seu discurso não passava da linguagem ordinária dos jogos táticos entre poderes econômicos e autoridades simbólicas.” (Ibidem, p.65). No jogo das palavras, o quiproquó foi usado como estratégia ${ }^{38}$.

Oriunda das práticas militares, natural que conste do vocabulário político e econômico, no discurso de peritos e de especialistas. Deslocada para a área da Educação, não é incomum a palavra estratégia referir-se aos meios pensados pelo professor para fazer com que o aluno aprenda um conteúdo ou, mais atualmente, desenvolva habilidades.

Essas estratégias devem se materializar na sala de aula, território de confronto, mas também da ocasião, dentro do qual um elemento surpresa em forma de uma visita ou de uma pergunta, de uma resposta, de uma sugestão, de um comentário ou de uma ideia inesperada de um aluno, por exemplo, pode fazer com que o professor precise rever sua estratégia.

Diferente da metodologia, mesmo que às vezes seja parte dela, as estratégias estão ligadas ao ensino e não diretamente à Educação (estratégias de ensino, nos planos de aula, por exemplo). Têm um caráter mais técnico e menos filosófico. Diz de formas de agir com um fim determinado; visa resultados concretos - a aprendizagem - mensuráveis, até, e localizados - ao final da aula, em um exame ou em atividades diversas, mas sempre em um e de um lugar de controle.

O ensino vai se dissolvendo em técnicas, em práticas, em instrumentalização de atividades, em procedimentos, aproximando-se do pragmatismo, do utilitarismo. Do professor, espera-se que saiba fazer, que

\footnotetext{
38 Certeau (2014, p.93-95) define estratégia como "o cálculo (ou a manipulação) das relações de forças que se torna possivel a partir do momento em que um sujeito de querer e poder (uma empresa, um exército, uma cidade, uma instituição científica) pode ser isolado". Se a estratégia, segundo o autor, é um lugar de poder, de dentro do território do inimigo está a tática, a "arte do fraco", que consiste em "dar um golpe", aproveitando uma ocasião.
} 
tenha o conhecimento técnico. Das escolas, que sejam "acolhedoras, como templos do Ensino”. Do aluno, a passividade da contemplação, a que o espaço convida.

Neste "lugar sagrado", o ensino é a representação da Educação, enquanto espaço. Ginzburg (2001), no ensaio Representação: a palavra, a ideia, a coisa, conta que o termo representação, como hábito, tem sua origem nos séculos II e III, nos rituais fúnebres na Antiguidade Clássica, e que tem circulado, desde então, por diversas civilizações. Assinala a ambiguidade do termo como justificativa de sua abrangência na atualidade: “a representação faz as vezes da realidade representada e, portanto, evoca a ausência; por outro lado, torna visivel a realidade representada e, portanto, sugere a presença.” (Ibidem, p.85).

Tomando o filósofo, historiador e ensaísta franco-polonês, Heródoto VI, (Ibidem, p.58), Ginzburg conta, também, que, “em Esparta, quando um rei morria na guerra, fazia-se seu simulacro, que era exibido então num leito adornado". (Ibidem, p.92). Como um simulacro adornado, o Ensino substitui a Educação em um espaço que é seu, por excelência. Como uma imitação, cristaliza práticas. Evoca (a palavra) e sugere (a ideia). Mas não é (a coisa).

Nesse substituto ritual, o lugar do ensino é um lugar simbólico, um não lugar ${ }^{39}$, uma passagem entre uma prática (o fazer do professor) e o seu resultado (a aprendizagem operacionalizada do aluno). nserido no lugar da Educação e marcado por uma erosão, o que se ensina com o que se ensina? Eis o terreno da astúcia.

Sendo (o ensino) a representação do diálogo, nas ementas, não é a Educação, nem a Linguagem nem seu simulacro ${ }^{40}$. Há uma cisão que separa,

\footnotetext{
39 Em oposição à estabilidade do lugar, Certeau (2014, p. 169-172) chama de "não lugar" uma "maneira de passar" de um lugar (de origem) a outro.

40 Jean Baudrillard (1991) diferencia a representação da simulação. Para ele, a representação "parte do princípio de equivalência entre o signo e o real", enquanto que a simulação "parte da
} 
pela presença do nome, aquilo que constitui uma falta - o elo. Nessa cisão, o ensino é a travessia que, "ao mesmo tempo, funciona como imagem invertida: dá lugar à falta e a esconde [...]; exorciza e reconhece uma presença da morte no meio dos vivos." (CERTEAU, 2013, p.91). Assim também é o colar de miçangas:

Mas a imagem do colar também não é o colar.

O não-lugar articula aquilo que não é, e/ou/porque o que deseja ser, naquilo que as linhas de pesquisa propõem: articuladas. Explico: as suas ementas constituem um registro d(e um)a realidade, projeta uma imagem de si, criando, nessa projeção, um novo jogo de imagens, na medida em que projeta, também, a imagem do pesquisador que participa da linha de pesquisa e daquele que quer e/ou que pode participar, além de projetar a imagem do ambiente, do contexto, da "linha" na qual a pesquisa vai se desenvolver.

Certeau (1985, p.11) diz que "Em um jogo, não há simplesmente os postulados, as regras e a 'mão', mas há, também, uma maneira de jogar.” É, então, a partir dos jogos possiveis com essas imagens, de como os lugares vão sendo ocupados nos movimentos da travessia que se abre um portal por onde o caminhante e/ou o observador (o pesquisador) consegue fazer e/ou entrever possibilidades de trajetórias, passagens e recantos - espaços para "astúcias gazeteiras" ou para a repetição de caminhos já abertos. Assim como as miçangas do colar, a dessemelhança, a cisão e a travessia forjam a identidade. Assim como no colar de miçangas, a universidade forja a identidade na articulação/desarticulação entre Linguagem e Educação.

A possibilidade do diálogo aparece nesse não-lugar, expondo, no atravessamento das miçangas pelo fio que não está, necessariamente exposto, o desejo da articulação. Quando se fala em Linguagem, sabe-se que está se falando de uma área; quando se fala em Educação, sabe-se que se está, de Calvino, acredito que a relação entre os postais e a cidade se dá nos dois níveis. 
também, falando de uma área. Mas quando essas duas áreas se juntam em um nome só, próprio que lhe é, sabe-se do que se está falando? E falando nisso, o que se está dizendo? Olhando para o colar, ele mostra uma área, ele mostra as miçangas ou uma composição, criando outra coisa, dissemelhante a cada uma das miçangas que o compõem, em separado?

Nos espaços onde a articulação vira diálogo, este passa a ser um acontecimento, na medida em que recorta e organiza um fato, condicionando, por consequência, o discurso (CERTEAU, 2013, p.p.104-105). O diálogo estabelecido no com-fronto entre interlocutores, marcados pela conjunção aditiva "e", a princípio e por princípio, orienta semanticamente o olhar para um lugar $^{41}$ que não é nem o próprio da Linguagem, nem o próprio da Educação, mas um outro; esse diálogo marca, simultaneamente, a presença das duas áreas articuladas pelos nomes e a ausência das mesmas, em suas particularidades. Por isso, estas eu considerei miçangas maiores, com uma transparente entre elas, a de discurso politico-oficial.

Não se trata, portanto, de uma soma, mas da abertura de uma passagem, o momento de um atravessamento - das miçangas pelo fio do colar; das áreas pelo ensino: o não-lugar.

Certeau (Ibidem, p.75) diz que “Um trabalho é 'cientifico' quando opera uma redistribuição do espaço e consiste, primordialmente, em se dar um lugar [...] por uma ação instauradora e por técnicas transformadoras." Na travessia, espera-se encontrar o novo, o mesmo (para fazer a oposição a) e o diferente. No Quadro 17 aparecem duas ementas de linhas de pesquisa cuja articulação expõe, no mesmo lugar, Educação e ensino, e Linguagem e língua:

\section{Quadro 17: Educação e ensino / Linguagem e língua}

\begin{tabular}{|l|l|l|}
\hline E3 & $\begin{array}{l}\text { Educação e } \\
\text { Linguagem }\end{array}$ & $\begin{array}{l}\text { Aspectos cognitivos, sociais e históricos das práticas linguísticas, } \\
\text { lingua portuguesa na aprendizagem escolar; linguagem verbal e } \\
\text { outras linguagens; cultura escrita, alfabetização e letramento; }\end{array}$ \\
\hline
\end{tabular}

\footnotetext{
${ }^{41} \mathrm{Na}$ acepção que lhe dá Certeau (2014, p.184).
} 


\begin{tabular}{|l|l|l|}
\hline E29 & $\begin{array}{l}\text { Lingua e } \\
\text { ensino }\end{array}$ & $\begin{array}{l}\text { Exame das normas e registros que caracterizam o português nos } \\
\text { níveis semântico-lexical, fonético-fonológico, morfossintático e } \\
\text { textual, com vista ao seu ensino como língua 1 e língua } 2 .\end{array}$ \\
\hline
\end{tabular}

No primeiro caso, o que há de específico pode ser genérico: o que há de prática linguística pode ser prática comunicativa, tanto que a linguagem não é propriamente verbal, mas abarca outras linguagens; a escrita não trata necessariamente do ato de escrever, mas de uma cultura letrada por meio da alfabetização e do letramento. Adiante há um escape para a literatura e outro salto para termos como oralidade e escrita, como se esses conceitos prescindissem de marcas capturadas de jogadas linguísticas. A ênfase é dada aos aspectos cognitivos, sociais e históricos.

No segundo caso, acontece o contrário: a ênfase está na materialidade linguística como conteúdo do ensino, que não se abre para a abrangência da linguagem. Concentra-se na norma, no registro, no nível semântico-estilístico, fonético-fonológico, morfossintático; no ensino do português como língua 1 e 2 , e não como manifestação de linguagem.

Os nomes das linhas de pesquisa, sem serem exatamente os mesmos, não são, tampouco, totalmente diferentes: entre linguagem e lingua e entre educação e ensino há uma relação semântica pressuposta, de pertencimento e abarcamento $^{42}$. As ementas descrevem o que lhes interessa, enquanto objetos de pesquisa.

Vê-se dois lugares onde a articulação entre as áreas se dá: o lugar (por excelência) da Educação (programa de Educação) e o lugar (por excelência) da Linguagem (programa de Letras). Esses lugares marcam, também, mesmo no

\footnotetext{
42 Certeau diz um pouco dessa relação de contingência tanto nos processos de "constituição do nome próprio" (2013, p. 232) como na descrição das feições do "homem ordinário". (2014, p.57).
} 
diálogo e por isso mesmo, uma relação de alteridade; uma clivagem que prenuncia uma relação de poder (Ibidem, p.195).

Há vários pares interessantes que se formam, no atravessamento entre as áreas nesse diálogo. No que se refere aos conteúdos (das ementas), posso apontar:

a) Aspectos cognitivos (das práticas linguísticas) X exame das normas;

b) Aprendizagem escolar X niveis (semântico-lexical, fonético-fonológico, morfossintático e textual);

c) Aquisição de lingua materna (cultura escrita, alfabetização e letramento) X aquisição de língua estrangeira (língua 2).

É possivel identificar enunciadores que levam consigo as marcas dos lugares de onde ecoam suas vozes, que, tentando convergir para o lugar da articulação, acabam por dispersar-se e reverberar nos seus lugares de origem: quando a generalidade fala, a especialidade é o seu objeto; se é a especialidade que fala, a generalidade ocupa a posição de suporte metodológico.

A relação entre as palavras linguagem/lingua e educação/ensino, a princípio, hiperonimicas, acabam, nesse contexto, por se constituir como eponímicas: a articulação empresta seu nome e lugar ora à Linguagem, ora à Educação, assim como a linguagem empresta seu nome e lugar à língua, e o ensino empresta os seus à educação, de forma que "o discurso destinado a dizer o outro permanece seu discurso e o espelho de sua operação.” (Ibidem, p.41). Nesse ambiente, então, a Educação vê a Linguagem como o outro, e viceversa.

Educação e Linguagem (assim como escritura e oralidade) não postulam, no entanto, uma oposição, pois que não há uma hierarquia a inverter. A oposição, de acordo com Derrida (2011), tem como última referência a presença de um valor ou um sentido que seria anterior à própria diferença. A 
diferença, no sentido que lhe dá o filósofo francês, diz daquilo que, na escrita, é e, ao mesmo tempo, não é; um duplo movimento que cria o diferente e o dissemelhante; um processo gerador de sentido, no jogo do que se presentifica e se ausenta, por escolha. É o que faz com que o movimento da significação não seja possivel a não ser que cada elemento dito 'presente', que aparece sobre a cena da presença, se relacione com outra coisa que não ele mesmo, guardando em si a marca do elemento passado e deixando-se já moldar pela marca da sua relação com o elemento do futuro. (DERRIDA, 2001, p.31-34).

Para Certeau, o plural, "um mar anônimo no qual a criatividade murmura um canto violento" (CERTEAU, 2003, p.17), é o originário; e a diferença, nesse sentido, é constituinte de seus termos. O plural é o complexo, o múltiplo, o heterogêneo, o diverso, na diversidade de singularidades, de fazeres que não se fecham mais, necessariamente, no pertencimento a um grupo social ou a uma classe econômica. Nessa compreensão, a articulação entre Linguagem e Educação é plural e constituída por diferenças.

O ponto de convergência das vozes que ressoam das ementas é o ensino, interesse comum, sob a forma de nome comum, que aparece em ambas as ementas, das duas linhas de pesquisa, vinculadas às duas áreas. Um "rastro" do que pode haver de performativo no ato de nomear (as linhas de pesquisa, no caso), na medida em que "organiza o que enuncia", que "altera um lugar (perturba-o), mas não funda nenhum”. (CERTEAU, 2013, p.226).

Olhando para o ensino como um ponto de chegada de uma trajetória construída na travessia, aquilo que produz o diálogo, da mesma forma que a história produz o passado (CERTEAU, 2012, p.163), ele se constitui em uma voz (um enunciador) que pode ajudar, nas dimensões em que ele se apresenta, a fazer aparecerem as leis da articulação e os silêncios que a atravessam. (REVEL, 1989) 
O ponto de articulação entre Linguagem e Educação se dá no espaço da formação do professor de Língua Portuguesa. Um espaço comum de onde as ementas se dão como postais cujas imagens mostram e escondem duas realidades: a que se diz que é e, ao ser, mostra que não é. O ponto se articula à sua ausência e existe por meio dela: o discurso político, uma miçanga articuladora.

Não raro, o novo é estranho e aquele que está deslocado de seu lugar de identidade - de sua língua ou de sua fala -, estrangeiro. O que há de estranho no estranho e de estrangeiro no estrangeiro é o lugar que ocupam, do lado de cá ou de lá do corte; o lado de lá ou o lado de cá do poder, muitas vezes, o domínio da linguagem, na esfera discursiva de uma área, de um ambiente, de um espaço, de um lugar.

O corte não é feito pelo estranho, mas pelo que estranha. É ele que delimita, no mapa de suas identidades, o lugar da alteridade. É ele que separa sob a efigie de outro aquilo que ele não é, mas, de uma certa forma, deseja possuir, em termos de ser capaz de compreender, de apreender, de depreender; na forma e no lugar de explicar, para os seus, como é a estran(geir)heza que vê no outro que assim identificou (pela escrita); pela produção da imagem transmutada em colar. O corte e a representação constituem um exercício e uma demonstração de poder.

Linguagem e Educação são "cidades diferentes (que) sucedem-se no mesmo solo" e que captam, para si, o domínio da articulação onde esta não está (daí a relação de alteridade); seria, ao mesmo tempo, por exemplo, o solo comum que suporta o movimento de várias cidades na produção de um "espaço próprio" (CERTEAU, 2014, p.160), onde a articulação se efetiva em diálogo.

Há algo que identifica, ao mesmo tempo em que diferencia, a Linguagem da Educação - o lugar, onde situam-se as linhas de pesquisa. Há, pois, um 
movimento que pretende provocar alterações no lugar próprio para a recriação do espaço.

O lugar próprio (das áreas delimitadas) é o lugar da articulação das estratégias do poder. Desse lugar, ouve-se a hierarquia da voz da área. Mas, no diálogo, dinamiza-se o espaço, preparando o campo das táticas, assim como no colar. 


\section{CONSIDERAÇÕES FINAIS: ÚLTIMOS ARREMATES}

O que é bom para o dono é bom para a voz

O que é bom para o dono é bom para vós

O que é bom para o dono é bom para nós.

(HOLLANDA, 1981)

Havia colares, no início desta tese. Eu os apresentei, em coleção, como as ementas das linhas de pesquisa em cujos nomes estavam articuladas a Linguagem e a Educação. Eu vi as miçangas, as vozes enunciativas que as punham em posições de sujeito e transformava a articulação em diálogo. Nessas posições, projetei as imagens de uma e de outra, para uma e outra.

Daí vi que, nessas posições, a Linguagem é um objeto de estudo para a Educação e que a Educação é um ambiente onde a Linguagem acontece como um conteúdo - complexo, variado, múltiplo. Vi que há um fio que atravessa essas miçangas e que é quem torna o colar possivel - o ensino. E que há determinações que, muitas vezes, dão a forma do colar - o(s) dono(s) da voz.

É que acabei vendo que, na tessitura do colar, há algo que está na sua gênese de fibra, quase nem linho ainda, e também no seu acabamento final: uma necessidade que, como acontecimento discursivo, é marcada pela censura e pela autorização - as vozes e seus donos. Nessa dinâmica, "O dono prensa a voz / a voz resulta um prato / que gira para todos nós" (HOLLANDA, 1981), alunos, professores e pesquisadores. Há que se encontrar o espaço da astúcia para "se desatar de tantos nós / nas cordas de outra garganta" (Idem).

As ementas das linhas de pesquisa em imagem de colar que tomei como dados não me mostraram apenas os movimentos de sua escritura ou a vontade de dezescrevê-las ${ }^{43}$. Através dessa imagem, fui desenvolvendo um jeito de

43 O verbo faz referência ao projeto do Grupo de Estudos e Pesquisa Produção Escrita e Psicanálise (GEPPEP), Movimento de Dezescrita, iniciado em 2013. O neologismo nomeia a 
traçar, vendo o acontecimento, deslocandondo essas ementas do lugar de conforto de estar autorizada por uma linha de pesquisa, para um lugar de conflito de vozes que se cruzam, nem sempre em uníssono. Troquei, em uma certa medida, a posição de quem aponta para uma posição de quem desaponta. Esse desapontar se refere a momentos necessários da constituição do pesquisador, no processo de pesquisa: o questionamento das certezas, a desconstrução do óbvio e o arrebatamento.

O abalançamento das certezas não diz do risco que se corre, mas de uma atitude que se assume, na medida em que lugares como o dos autores das ementas, por exemplo, a voz da instituição, é colocada em xeque quando se está no processo de investigação. Algumas respostas vão chegando e sem escolha expõem o que normalmente não se chega a ver. A escrita de uma tese é um desafio de expor, para além da pesquisa, uma forma de ver o mundo, naquilo que é analisado nos dados. É a implicação de si.

A experiência, naquilo em que ela tange ao tempo e à intensidade de vivências, pode causar uma cegueira. Contra essa cegueira do hábito, do costume, da repetição, do olhar-para-o-próprio-umbigo, está a desconstrução do óbvio, na medida em que este tenha se constituído na exaustão da cópia, como prática. A ocasião não cria o ladrão, nem a tradição, o inquestionável. É algo a ser dezescrito ao longo da pesquisa.

O arrebatamento diz, aqui, sobretudo, de um exercício de superação, um movimento que vai de um inferno a outro - do suposto saber ao querer saber - condição da pesquisa -, instâncias necessárias à produção do conhecimento. Há que se estar sempre em um "estado de desconfiança" para

reversão de um processo no qual o tempo (epistemológico), o uso (habitual) e o meio (acadêmico) deram por findado. Esse jeito de dezescrever insere, na história do conhecimento, a pluralidade da produção intelectual e a singularidade de quem produz. Esse neologismo assume, no projeto, uma tríplice acepção: 1) a de reversão de um processo já concluído, no que se refere à obediência irrefletida aos textos e aos autores de referência; 2) a de pluralidade, no sentido de que há de se reconhecer as diversas vozes que falam de e em um texto; e 3) a de necessidade de excelência na produção de um texto considerado bem escrito. 
aplicar, produtivamente, conceitos da Análise do Discurso para o tratamento de dados colhidos em contextos educacionais - foi algo essencial que aprendi com o meu orientador: a desobediência necessária que atravessa o posto até chegar aos seus determinantes. O que se encontra, para além dessa superfície, não raro é algo mais complexo e nem sempre positivamente surpreendente.

É também um comportamento, essa desobediência; uma forma de lidar com a teoria e de olhar para o dado; de aprender que discurso é coisa feita de gente, porque o que determina é a história, mais do que de palavras, e que é preciso desconfiar sempre - não necessariamente das pessoas, mas do que elas fazem com o que dizem, porque desconfiar não é achar que é tudo é mentira ao contrário: é compreender a verdade que está, de formas diversas, em tudo o que se diz, nos efeitos de sentido que isso cria.

Desconfiar, aprendi que é ficar atento, que é não permitir que um nome, por si só, seja algo além somente daquilo que do signo é arbitrário, quando se está analisando um discurso; que o significado de um nome é feito mesmo do seu uso, lambuzado, sobretudo, de sua história; e que essa história é a escrita de um lugar, recortada por um tempo; que quem faz esse recorte é um sujeito, que tem um nome... e volta tudo para o começo.

Desconfiar talvez seja saber que "as palavras se sujam de nós, na viagem", como diz Manoel de Barros (1999). Sobretudo porque, em uma certa medida - pequena que seja - a possibilidade de escolher entre uma e outra, em arranjá-las de um certo modo, existe, principalmente na escrita. É a atividade epilinguística. As palavras que se escolhe, nesse trato que se dá à linguagem para dizer, dizem de quem as escolhe para além do estilo - dizem de uma história (ou de uma histori-cidade). Para o leitor do poema, essa escolha é para o deleite; para o analista, a escolha é para a desconfiança, uma atitude 
produtiva, em termos de produção de sentidos e de conhecimento. Nesses termos, a desconfiança é trabalho ${ }^{44}$ e é deleite também.

As linhas de pesquisa em Linguagem e Educação criaram um lugar para o exercício dessa desconfiança; um lugar instituído, um discurso autorizado e referendado, no qual o diálogo, certamente, se fundaria. Da desconfiança e da análise, consegui chegar a algumas conclusões. Mas continuei desconfiando. E então busquei ver como o que as ementas propunham se concretizavam, na forma dos trabalhos desenvolvidos de dentro das linhas de pesquisa.

Por um processo de amostragem, cheguei a 346 teses e dissertações defendidas ao longo de 10 anos, em 4 universidades ${ }^{45}$, orientadas por 30 professores distintos. Desses trabalhos, 37,65\% têm, como objeto de estudo declaradamente o ensino. 29,32\%, a escrita; $13,27 \%$ a leitura; $11,11 \%$ a produção de discursos e $8,64 \%$ a formação de professores. Dos trabalhos que tratam da escrita, sobretudo, mas também da leitura, alguns versam sobre intervenções no texto escrito e sobre trabalhos com projetos e leitura, que tocam, em uma certa medida, o ensino também, assim como os sobre formação de professores para a lida com o ensino, ou seja, a aula, e sobre a produção do discurso (sobre ensino ou sobre atores ou documentos ou contextos de ensino).

Mesmo considerando ser apenas uma amostra e que esses números não dão conta, portanto, da totalidade dos trabalhos desenvolvidos em todas as 31 linhas de pesquisa que compuseram o corpus desta tese, posso considerar que há, de fato, um grande interesse pelo ensino nesse lugar onde a Linguagem e a

\footnotetext{
44 Penso aqui na categoria "trabalho" de Lukács (1979), que retoma o lugar de centralidade do trabalho no processo de humanização do homem, de Engels (1979), para quem o trabalho "é a condição fundamental de toda a vida humana; e o é num grau tão elevado que, num certo sentido, pode-se dizer: o trabalho, por si mesmo, criou o homem.” (p.215). Para Lukács, o trabalho é o que permite a passagem (evolução) do homem da esfera biológica para a esfera social, na qual ele é capaz de transformar, não sem sobressaltos, mas a seu favos, a natureza. 45 Busquei na Plataforma Lattes as orientações de teses e dissertações concluídas de todos os professores das linhas de pesquisa em Linguagem e Educação, nos programas de pós em Educação, que elenquei no capítulo 3 desta tese (mais especificamente no item 3.1), de 4 das 5 universidades (E1, E9, E17 e E18). Uma delas (E3) não têm, disponivel para consulta, o corpo docente da universidade ou da linha de pesquisa)
} 
Educação dialogam nas ementas das linhas, talvez não necessariamente entre as áreas. O que pode ratificar as conclusões a que cheguei com a análise dos dados tem base no âmbito das linhas, porque é possivel perceber que a definição da linha já nasce de quem participa desse diálogo.

a) O lugar do ensino no atravessamento da Linguagem para a Educação é o lugar do fio do colar. Ele não só as atravessa, áreas e miçangas, mas as une, em composição. Mesmo assim, algumas vezes estabelece a justaposição. A com-posição que o fio cria favorece o diálogo. Nesse sentido, a posição do ensino, na articulação, é a daquilo que dispõe a Linguagem e a Educação em posição de sujeitos que interagem, em um ambiente específico - o diálogo - com tudo aquilo que lhes determina enquanto áreas: conteúdos, afinidades, objetos.

b) A relação entre Linguagem e Educação proposta pelas ementas é a relação entre um espaço - os espaços onde acontece o ensino, onde se dá a transferência - e um instrumento e/ou um objeto: aquilo com o que se olha ou para o que se olha. A hierarquia entre um e outro sujeitos, no diálogo, é construída pela voz da autoridade instituída em um ambiente específico.

Por essa "voz da autoridade instituida em um ambiente específico" eu falo das necessidades das linhas de pesquisa frente a determinações de instâncias superiores ${ }^{46}$, de trabalhos já desenvolvidos por alunos-professorespesquisadores quando chegam à pós, mas, sobretudo, aqui, falo da orientação da pesquisa, que deve ter afinidade com a formação, com os interesses ou com o gosto do orientador.

\footnotetext{
46 No XII Encontro da Linha de Pesquisa Linguagem e Educação da Universidade de São Paulo (realizado em maio de 2016), por exemplo, foi apresentada a proposta de integração das áreas de "Linguagem e Educação" e "Psicologia da Educação", com o objetivo de construir uma identidade para a nova área de pesquisa, "Educação, Linguagem e Psicologia", que substituiu "Linguagem e Educação", e se desdobrou em quatro linhas: Oralidade, Alfabetização, Multiletramentos e Arte; Teorias e práticas para a educação linguística e literária; Psicanálise e educação; e Psicologia e educação.
} 
Digo que há uma marca bastante forte da graduação, dentro dos caminhos tanto das pós-titulações como no encaminhamento das orientações, nos orientadores. Mas há algo, a que me refiro, que vai além disso, na produção dessa "voz da autoridade instituída" de que falei. Um dos professores que aparecem na amostragem, por exemplo, orientou 29 trabalhos (todos dissertações de mestrado) entre 2007 e 2015 (data da última orientação concluída disponivel, para consulta, na Plataforma Lattes). Dessas 29 dissertações, 11 são sobre "a construção dos sentidos" de alguma coisa (de um projeto $\mathrm{X}$ para os acadêmicos $\mathrm{Y}$; do letramento para os pesquisadores; da disciplina X para os alunos $\mathrm{Y}$; do ensino-aprendizagem para os estudantes etc), e esse objeto de estudo está expresso nos títulos, nos subtítulos e/ou nos resumos dos trabalhos concluídos. É muito mais provável que esse interesse pela "construção dos sentidos" seja algo que diga mais da identidade do orientador do que da universidade, da linha de pesquisa ou do interesse dos próprios pesquisadores, o que seria uma enorme coincidência. É, então, uma "voz da autoridade instituída" que se cruza, na articulação entre Linguagem e Educação.

c) Há vozes cujo tom é mais comum na área da Linguagem e outras que são mais específicas, tradicionalmente, da área da Educação, que ecoam quando se fala, por exemplo, em aprendizagem de uma língua estrangeira ou em aprendizagem da escrita, por exemplo. São vozes produzidas na formação, na experiência e no trabalho. Essas vozes se cruzam em um ambiente chamado diálogo e em um fio (de atravessamento) chamado ensino: o fio que arremata um ponto para atravessar outra miçanga. As formas de tecer o colar segue a orientação de uma outra voz, que é a voz da instituição.

Há determinações materiais expressas nessas vozes que dizem como o fio deve atravessar essa e não aquela miçanga. Mesmo assim e por causa dessa voz mesmo, cria-se o espaço das táticas, os fazeres que, dentro do instituído, "burlam" o que está materialmente ou culturalmente determinado desse mesmo 
lugar, de uma forma legítima, com regras próprias para o desenvolvimento e para a compreensão de atividades que não estão exatamente dentro dos saberes prestigiados pela tradição e/ou pela cultura.

Esse deslocamento cria o não-lugar do ensino no diálogo entre a Linguagem e a Educação que defendo nesta tese. Um desvio, digamos assim, do que é recebido, pelos trabalhadores em Educação como produto a ser consumido, seja no que se refere a conteúdos, a temas principais ou transversais, às exigências do mercado ou do mundo do trabalho.

O não-lugar do ensino, como o fio que sustenta as miçangas em colar e que dá visibilidade a elas são as maneiras de fazer, de professores, pesquisadores, orientadores e alunos cujas invenções, provenientes das práticas, de sua "liberdade gazeteira", criam uma nova lógica do cotidiano nos espaços de Educação, na medida em que evidenciam diferenças e astúcias onde há uniformidade. Cabe, por isso, nesse não-lugar do ensino, em espaços de Educação, a pesquisa, não como algo que complementa o ensino, em outra instância da formação, mas como um recurso dele.

Certeau (2014) diz que o urbanismo define geometricamente a rua, mas que esta é transformada em espaço pelos pedestres, ou seja, que os sujeitos se apropriam dos lugares - criando espaços - pelo uso que fazem deles, pela forma como o ocupam e o compartilham, como ali interagem, pelas vivências que ali têm. A Linguagem, em sua concepção não instrumentalizada, se insere no "mundo" da Educação como os passos dos caminhantes vão moldando os lugares e transformando-os em espaços. Afetam o ser-professor, o ser-aluno e a relação entre eles. Afetam o conhecimento na ação com-partilhada de aprender e, como consequência, de ensinar. O que fica marcado (lembrando a etimologia da palavra ensinar) é o que foi moldado, com passos.

O ensino que está previsto da concepção instrumental da linguagem é um ensino transmissivo, no qual alguém (o professor ou outro emissor menos 
formal) que (supõe-se que) sabe mais transmite uma "mensagem" (uma informação ou um conteúdo) a outro alguém (o aluno ou outro receptor) que (supõe-se que) sabe menos. E o que se espera, como resultado, nesse esquema, é que o receptor receba e compreenda a mensagem; seja capaz, por exemplo, de repassá-la ou repeti-la. Este é o aprendizado.

Ao deslocar o ensino da concepção da linguagem como instrumento de comunicação para tomá-la como um processo de interação, a transmissão (do conteúdo) é algo que acontece, mas que não vai sozinho, como uma “informação". Quem ensina, nessa perspectiva, transmite a experiência que tem com aquilo que elabora - o seu trabalho. O resultado desse ensino, para além da reelaboração, da retransmissão e da repetição - o seu aprendizado subjetivo - é "um resultado inesperado47" (LESSA, 1996, p.12), inapreensivel, no que poderia caber, por exemplo, em um modelo de avaliação institucional.

A hipótese de que, na articulação, o ensino atravessa os sujeitos constituídos nos seus lugares (os lugares das áreas, uma e outra), como o fio atravessa as miçangas, se confirma. Mas ele não expõe, necessariamente, instabilidades, geradas por vozes que falam de um lugar de saber ou de um lugar de poder. O que ele expõe são as posições de sujeitos que Linguagem e Educação assumem, quando em diálogo. É esse diálogo que delineia o nãolugar do ensino onde a Linguagem (as concepções, as formas, os niveis) o afeta, na Educação.

Há o momento em que a escrita precisa encerrar, em que o ponto final é necessário. Há um cansaço emergente do trabalho da escrita que não

\footnotetext{
47 A utilização, aqui, dessa expressão ("um resultado inesperado") é uma referência à história de Ikursk, um "medroso" que, para se proteger de um enorme tigre dente-de-sabre que rondava sua aldeia e já havia destroçado criações, pessoas e bravos guerreiros, resolveu construir, para si, um machado tão grande que lhe servisse de argumento para NÃO IR, com seus companheiros, à caça à ameaçadora fera. E assim foi, até que "algo inesperado" aconteceu: ao encontrar, ao acaso, o tigre, os fortes espasmos de pavor do medroso fizeram-no arremessar, em trajetória improvável, o descomunal machado, que, atingindo a cabeça do animal, acabou por matá-lo. E então, Ikursk foi nomeado chefe da tribo e o machado foi reconhecido como um objeto mágico. (LESSA, 1996, p.12-15).
} 
acompanha o interminável da pesquisa, sua condição - enquanto a escrita (da história) tem que ser concluída, a história continua (CERTEAU, 2013): “a representação escriturária é "plena"; preenche ou oblitera as lacunas que constituem, ao contrário, o próprio princípio da pesquisa, sempre aguçada pela falta." (p.90).

Aguçado pela falta que (im)pulsiona a pesquisa, o desejo, esse, continua. A tese recebe esse fecho. 


\section{EPÍLOGO: O DESEJO E O COLAR}

O que eu desejo ainda não tem nome.

(LISPECTOR, 1980, p.50)

A palavra desejo tem origem nas estrelas. Das estrelas ao desejo, o caminho que a palavra toma é uma queda livre: de-, prefixo latino que indica um movimento (de cima) para baixo, e siderium, estrela em latim. A imagem da estrela cadente, então, descreve o desejo, na sua origem e em seu percurso de mergulho. Ao contrario de com-siderar, que tem a mesma raiz, desejar é sair de um lugar elevado para fazer um percurso próprio e, nesse sentido, escolher o seu destino - a vontade, nascida de uma escolha. E escolher pressupõe abrir mão de alguma(s) coisa(s). Nesse sentido, desejar é, também, marcado por uma falta. Essa dupla face do desejo se mostra em seus usos: desejar pode ser querer, com um sentido mais ativo, ou precisar, em um sentido mais passivo, dentre outras nuances - do desejo.

O desejo do colar também me mostrou uma origem e descreveu, para mim, uma trajetória, que foi a trajetória da organização dos dados e de escrever uma tese. Antes, já houvera o desejo de escrever meu nome. Há uma vontade e uma falta que me movem, sempre no campo do simbólico. Sinto que sigo, que continuo seguindo por esse caminho.

Agora, na condição de pesquisadora-artesã, não exponho um colar, mas o que pude aprender com ele, no processo de análise dos dados. Não posso garantir o que não se passou na trajetória produtiva e criativa da artesã do colar que observei para meu processo de escrita, mas, neste caso, tive que abstrair das miçangas para o fio encoberto por elas. Essa abstração me possibilitou falar do que não é tão visível: os discursos; e do fio que eles recobrem: o ensino. É assim que chego a esta tese: o ensino está recoberto por discursos que compõem o diálogo entre Linguagem e Educação nas Linhas de Pesquisa, assim como há um fio que sustenta a existência de um colar pelas miçangas. Da mesma forma que não existe colar sem fio, não existe diálogo 
entre Linguagem e Educação sem ensino, principalmente quando a aula não parece mais ser a última instância do ensinar.

Apresento esta tese: o ensino é um fio escondido porque ele é um conceito que só diz sob abstração. Ensinar é invisivel porque o colar dos colares é a vida, não tem fecho, atravessa paredes de desejos e ganha espaços interiores que nem se supõe existir. 
ABBAGNANO, NICOLA. Dicionário de filosofia. São Paulo: Martins Fontes, 2000.

ALMEIDA, Sonia. Escrita no ensino superior: a singularidade em monografias, dissertações e teses. São Paulo: Editora Paulistana, 2011. (Coleção Sobrescrita).

ALTMAN, Cristina. A pesquisa linguística no Brasil (1968-1988). São Paulo: Humanitas/FFLCH/USP, 1998.

ARAÚJO, Inês Lacerda. Do signo ao discurso: introdução à filosofia da linguagem. São Paulo: Parábola Editorial, 2004.

AUTHIER-REVUZ, Jacqueline. Entre a transparência e a opacidade: um estudo enunciativo do sentido. Porto Alegre: EDIPUCRS, 2004.

AUTHIER-REVUZ, Jacqueline. Palavras incertas: as não coincidências do dizer. Campinas: Editora da UNICAMP, 1998.

AZEREDO, José Carlos (org.). Lingua portuguesa em debate: conhecimento e ensino. Rio de Janeiro: Vozes, 2000.

BAKHTIN, Mikail. Estética da criação verbal. 4 ed. São Paulo: Martins Fontes, 2003.

BAKHTIN, Mikail. Problemas da poética de Dostoiévski. Rio de Janeiro: Forense Universitária, 1981.

BAKHTIN/VOLOCHÍNOV, Mikail. Marxismo e Filosofia da Linguagem. Tradução Michel Lahud e Yara Frateschi Vieira. 12a ed. São Paulo: Hucitec, 2006.

BARROS, Manoel de. Exercicios de ser criança. Rio de Janeiro: Salamandra, 1999.

BAUDRILLARD, Jean. Simulacros e simulações. Relógio d’Água: Lisboa, 1991.

BECHARA, Evanildo. Moderna gramática portuguesa. Rio de Janeiro: Lucena, 1999.

BLOCH, Pedro. Pedro Bloch entrevista. Rio de Janeiro: Bloch Editores, 1989.

BOURDIEU, Pierre. A distinção: crítica social do julgamento. São Paulo: Editora ZOUK, 2015. 
CASTILHO, Ataliba de. A cadeira de linguística no curso de letras. ALFA: Revista de Linguística, v.7, 1965.

CERTEAU, Michel de. A cultura no plural. Campinas: Papirus, 2003.

CERTEAU, Michel de. A escrita da história. Trad. Maria de Lourdes Menezes; revisão técnica Arno Vogel. 3.ed. Rio de Janeiro: Forense, 2013.

CERTEAU, Michel de. A invenção do cotidiano: 1. Artes de fazer. Petrópolis: Vozes, 2014.

CERTEAU, Michel de. História e psicanálise: entre ciência e ficção. Belo Horizonte: Autêntica, 2012.

CERTEAU, Michel de. Teoria e método no estudo das práticas cotidianas. In: SZMRECSANYL, Maria Ivone (Org.). Cotidiano, cultura popular e planejamento urbano. (Anais do Encontro). São Paulo: FAU/USP, 1985, p.p.319.

COLASANTI, Marina. Uma ideia toda azul. São Paulo: Global, 2006.

COURTINE, Jean-Jacques. A estranha memória da análise do discurso. In: INDURSKY, Freda, FERREIRA, Maria Cristina Leandro. Michel Pêcheux e a análise do discurso: uma relação de nunca acabar. São Carlos: Claraluz, 2007.

COUTO, Mia. O fio das miçangas. São Paulo: Companhia das Letras, 2009.

CUNHA, Celso, CINTRA, Lindley. Nova gramática do português contemporâneo. São Paulo: Nova Fronteira, 1985.

DERRIDA, Jacques. A diferença. Trad. Joaquim Torres Costa e António M. Magalhães. In: DERRIDA, Jacques. Margens da Filosofia. Porto: RÉS Editora, 1986.

DERRIDA, Jacques. A escritura e a diferença. São Paulo: Perspectiva, 2011.

DERRIDA, Jacques. Posições. Trad. Tomaz Tadeu da Silva. Belo Horizonte: Autêntica, 2001.

DUCROT, Oswald. Dizer e não dizer: princípios de semântica lingüística. São Paulo: Cultrix, 1986.

DUCROT, Oswald. O dizer e o dito. Trad. Eduardo Guimarães. Campinas: Pontes, 1987.

ENGELS, Friedrich. A dialética da natureza. Rio de Janeiro: Paz e Terra, 1979. 
FERREIRA, Aurélio Buarque de Holanda. Novo Aurélio Século XXI: o dicionário da língua portuguesa. Rio de Janeiro: Nova Fronteira, 1999.

FIORIN, José Luiz. A Criação dos Cursos de Letras no Brasil e as Primeiras Orientações da Pesquisa Linguística Universitária. In: Revista Línguas e Letras. Cascavel: UNIOESTE. V. 7 n. 12. p.11-25, 2006.

FOUCAULT, Michel. A arqueologia do saber. Rio de Janeiro: Forense Universitária, 1997.

FOUCAULT, Michel. A ordem do discurso. São Paulo: Edições Loyola, 2004.

FOUCAULT, Michel. As palavras e as coisas: uma arqueologia das ciências humanas. São Paulo: Martins Fontes, 2002b.

FREITAG, Bárbara. O individuo em formação: diálogos interdisciplinares sobre educação. São Paulo: Cortez, 1994.

GERALDI, João Wanderley (Org.) O texto na Sala de Aula. São Paulo: Ática, 2004.

GERALDI, João Wanderley. A aula como acontecimento. Anais da Semana da Prática Pedagógica Universidade de Aveiro, Portugal, CIFOP, 2003.

GINZBURG, Carlo. Olhos de madeira: nove reflexões sobre a distância. São Paulo: Companhia das Letras, 2001.

GINZBURG, Carlo. Mitos, emblemas e sinais: morfologia e história. São Paulo: Companhia das Letras, 1989.

HESSEN, Johannes. Teoria do conhecimento. 2.ed. São Paulo: Martins Fontes, 2003.

HOLlANDA, Chico Buarque de. A voz do dono e o dono da voz. Intérprete: Chico Buarque. In: HOLLANDA, Chico Buarque de. Almanaque: Ariola/Philips, p1981. 1CD. Faixa 4.

http://g1.globo.com/bom-dia-brasil/noticia/2015/01/botar-tranca-em-portaarrombada-diz-alexandre-garcia-sobre-posse.html. Acesso em 02/01/2015).

INDURSKY, Freda. Relatório Pinotti: o jogo polifônico das representações no ato de argumentar. In: GUIMARÃES, Eduardo (Org.). História e sentido na linguagem. Campinas: Pontes, 2008.

Koch e Marcuschi

$\mathrm{KOCH}$, Ingedore Grunfeld Villaça. Desvendando os Segredos do Texto. $2^{\mathrm{a}}$ ed. São Paulo: Cortez, 2003. 
KOCH, Ingedore Grunfeld Villaça.; ELIAS, Vanda Maria Ler e Compreender: os sentidos do texto. 3a ed., 3a reimpressão. São Paulo: Contexto, 2010.

KOVADLOFF Santiago. O silêncio primordial. Rio de Janeiro: José Olympio, 2003.

KUNDERA, Milan. A insustentável leveza do ser. São Paulo: Companhia das Letras, 2008.

LACAN, Jacques. O seminário, livro 8: a transferência. Rio de Janeiro: Zahar, 2010.

LAKOFF, George, JOHNSON, Mark. Metáforas da vida cotidiana. Campinas: Mercado de Letras, 2002.

LESSA, Sérgio. A ontologia de Lukács. Maceió: EDUFAL, 1996. V. 2 (Série Didática).

LIMA, Rocha. Gramática normativa da lingua portuguesa. São Paulo: José Olympio, 1992.

LISPECTOR, Clarice. Perto do coração selvagem. Rio de Janeiro, Editora Nova Fronteira, 1980.

LUKÁCS, Georg. A ontologia do ser social - os princípios ontológicos fundamentais de Marx. São Paulo: Livraria Editora Ciências Humanas, 1979.

MARIANI, Bethania. A escrita e os escritos: reflexões em análise do discurso e psicanálise. São Carlos: Claraluz, 2006.

MELO NETO, João Cabral de. Poesias completas. Rio de Janeiro: José Olympio, 1979.

MORAIS, Regis. O que é ensinar. São Paulo: EPU, 1986.

OLIVEIRA, Manfredo Araújo de. Reviravolta lingüistico-pragmática na filosofia contemporânea. São Paulo: Ed. Loyola, 2001.

ORLANDI, Eni Puccinelli. As formas do silêncio: no movimento dos sentidos. Campinas: Editora da UNICAMP, 1995.

PAVEAU, Marie-Anne. Os pré-discursos: sentido, memória e cognição. Campinas: Pontes Editores, 2013.

PÊCHEUX, Michel. A lingua inatingivel: o discurso na história da lingüística. Campinas: Pontes, 2004. 
PÊCHEUX, Michel. Análise automática do discurso. In: GADET, Françoise, HAK, Tony (Orgs.). Por uma análise automática do discurso: uma introdução à obra de Michel Pêcheux. Campinas: Editora da Unicamp, 2010.

PÊCHEUX, Michel. Discurso: estrutura ou acontecimento. Campinas: Pontes, 1990a.

PÊCHEUX, Michel. Semântica e Discurso - uma crítica à afirmação do óbvio. Campinas, Editora da Unicamp, 1995.

PIETRI, Émerson de. A constituição do discurso da mudança do ensino de língua materna no Brasil. 2003. Tese (Doutorado) - Instituto de Estudos da Linguagem da Universidade Estadual de Campinas. Campinas, 2003.

QUINTANA, Mário. Caderno H. São Paulo: Globo, 2006.

REVEL, Jacques, CERTEAU, Michel, JULIA, Dominique. A beleza do morto. In: REVEL, Jacques. A invenção da sociedade. Lisboa: DIFEL, 1989.

RIOLFI, Cláudia Rosa, BARZOTTO, Valdir Heitor. O inferno da escrita: produção escrita e psicanálise. Campinas: Mercado das Letras, 2011.

ROBIN, Régine. História e linguística. São Paulo: Cultrix, 1977.

ROSA, João Guimarães. Primeiras estórias. Rio de Janeiro: Nova Fronteira, 2001.

SAUSSURE, Ferdinand de. Curso de linguística geral. São Paulo: Cultrix. (Originalmente publicado em 1916). 1995.

SCHWARTZMAN, S. Um espaço para a ciência: a formação da comunidade científica no Brasil. Brasília, Ministério da Ciência e Tecnologia, Centro de Estudos Estratégicos, 2001. Tradução de Sérgio Bath e Oswaldo Biato. Endereço eletrônico: http://www.schwartzman.org.br/simon/spacept/espaco.htm.

SOARES, Magda. Linguagem e Escola: uma perspectiva social. São Paulo: Ática, 1986.

SOUSA, Antônio Paulino de, BARZOTTO, Valdir Heitor, SAMPAIO, Maria Lúcia Pessoa. Formação de professor de língua portuguesa: quando a linguagem e o ensino se encontram. São Paulo: Paulistana, 2010.

THOMPSON, Edward Palmer. A formação da classe operária II. São Paulo: Paz e Terra, 1987. 
THOMPSON, Edward Palmer. A miséria da teoria ou um planetário de erros. Rio de Janeiro: Zahar, 1981.

TONUCCI, Francesco. Com olhos de criança. Porto Alegre: Artmed, 2003.

TRAVAGLIA, Luiz Carlos. Gramática e interação: uma proposta para o ensino de gramática no $1^{\circ}$. e $2^{\circ}$. graus. São Paulo: Cortez, 1996.

VELOSO, Caetano. O nome da cidade. Intérprete: Adriana Calcanhoto. In: CALCANHOTO, Adriana. Senhas: Columbia Records, p1992. 1CD. Faixa 11.

WITTGENSTEIN, Ludwig. Investigações filosóficas. São Paulo: Editora Nova Cultural, 1999. (Coleção Os Pensadores). 
ANEXOS 


\begin{tabular}{|c|c|c|c|c|c|c|c|c|c|c|}
\hline & Instituição & $\begin{array}{l}\text { Administr } \\
\text { ação }\end{array}$ & $\begin{array}{l}\text { Grande } \\
\text { Área }\end{array}$ & Área & $\begin{array}{l}\text { Program } \\
\text { a }\end{array}$ & $\begin{array}{l}\text { Área } \\
\text { Básica }\end{array}$ & $\begin{array}{l}\text { Áreas de } \\
\text { Concentração }\end{array}$ & $\begin{array}{l}\text { Linha de } \\
\text { Pesquisa } \\
\end{array}$ & Ano & Ementa \\
\hline E1 & $\begin{array}{c}\text { UFAL } \\
\text { (universida } \\
\text { de Federal } \\
\text { de Alagoas) }\end{array}$ & FEDERAL & $\begin{array}{l}\text { CIÊNCIAS } \\
\text { HUMANAS }\end{array}$ & $\begin{array}{l}\text { EDUCAÇ } \\
\tilde{A} O\end{array}$ & $\begin{array}{l}\text { EDUCAÇ } \\
\tilde{A} O(M / D)\end{array}$ & $\begin{array}{l}\text { EDUCAÇÃ } \\
\mathrm{O}\end{array}$ & $\begin{array}{l}\text { EDUCAÇÃO } \\
\text { BRASILEIRA }\end{array}$ & $\begin{array}{l}\text { EDUCAÇÃ } \\
\text { O E } \\
\text { LINGUAGE } \\
\text { M }\end{array}$ & $\begin{array}{l}2001(\mathrm{M}) \\
\text { e } 2011 \\
\text { (D) }\end{array}$ & $\begin{array}{l}\text { Estudo da linguagem em } \\
\text { suas múltiplas dimensões, } \\
\text { em contextos educativos } \\
\text { diversos e em diferentes } \\
\text { niveis de escolarização, } \\
\text { visando à compreensão dos } \\
\text { processos de ensino e } \\
\text { aprendizagem fundados em } \\
\text { quatro pontos essenciais. }\end{array}$ \\
\hline E2 & $\begin{array}{c}\text { UFES } \\
\text { (Universida } \\
\text { de Federal } \\
\text { do Espirito } \\
\text { Santo) }\end{array}$ & FEDERAL & $\begin{array}{l}\text { CIÊNCIAS } \\
\text { HUMANAS }\end{array}$ & $\begin{array}{l}\text { EDUCAÇ } \\
\tilde{A} O\end{array}$ & $\begin{array}{l}\text { EDUCAÇ } \\
\tilde{A O O}(\mathrm{M} / \mathrm{D})\end{array}$ & $\begin{array}{l}\text { EDUCAÇÃ } \\
\mathrm{O}\end{array}$ & EDUCAÇÃO & $\begin{array}{l}\text { EDUCAÇÃ } \\
\text { O E } \\
\text { LINGUAGE } \\
\text { NS }\end{array}$ & $\begin{array}{l}1978(\mathrm{M}) \\
\mathrm{e} \\
2004(\mathrm{D})\end{array}$ & $\begin{array}{l}\text { Estuda } \\
\text { relacionadas com dões } \\
\text { processo de ensino- } \\
\text { aprendizagem } \\
\text { linguagens oral, escrita, } \\
\text { visual e matemática na } \\
\text { educação formal e não } \\
\text { formal. }\end{array}$ \\
\hline E3 & $\begin{array}{c}\text { UFMG } \\
\text { (Universida } \\
\text { de Federal } \\
\text { de Minas } \\
\text { Gerais) }\end{array}$ & FEDERAL & $\begin{array}{l}\text { CIÊNCIAS } \\
\text { HUMANAS }\end{array}$ & $\begin{array}{l}\text { EDUCAÇ } \\
\tilde{A} O\end{array}$ & $\begin{array}{l}\text { EDUCAÇ } \\
\tilde{A O O}(\mathrm{M} / \mathrm{D})\end{array}$ & $\begin{array}{l}\text { EDUCAÇÃ } \\
\mathrm{O}\end{array}$ & EDUCACAO & $\begin{array}{l}\text { EDUCAÇÃ } \\
\text { O E } \\
\text { LINGUAGE } \\
\text { M }\end{array}$ & $\begin{array}{l}\text { 1991(M e } \\
\text { D) }\end{array}$ & $\begin{array}{lr}\text { Aspectos cognitivos, sociais } \\
\text { e históricos das práticas } \\
\text { linguísticas, } \\
\text { portuguesa } \\
\text { aprendizagem na } \\
\text { linguagem verbal e outras } \\
\text { linguagens; cultura escrita, } \\
\text { alfabetização e letramento; } \\
\text { ensino de literatura; } \\
\text { oralidade e escrita. }\end{array}$ \\
\hline E4 & $\begin{array}{c}\text { UFLA } \\
\text { (Universida } \\
\text { de Federal } \\
\text { de Lavras) }\end{array}$ & FEDERAL & $\begin{array}{l}\text { CIÊNCIAS } \\
\text { HUMANAS }\end{array}$ & $\begin{array}{l}\text { EDUCAÇ } \\
\tilde{A} O\end{array}$ & $\begin{array}{l}\text { EDUCAÇ } \\
\tilde{A} O(F)\end{array}$ & $\begin{array}{l}\text { EDUCAÇÃ } \\
\text { O }\end{array}$ & $\begin{array}{l}\text { FORMAÇÃO DE } \\
\text { PROFESSORES }\end{array}$ & $\begin{array}{l}\text { LINGUAGE } \\
\text { NS, } \\
\text { DIVERSID } \\
\text { ADE } \\
\text { CULTURAL } \\
\text { E } \\
\text { INOVAÇÕE } \\
\text { S }\end{array}$ & 2011(M) & $\begin{array}{l}\text { Estudos da linguagem como } \\
\text { expressão, significação e } \\
\text { comunicação, das } \\
\text { inovações metodológicas e } \\
\text { tecnológicas e da } \\
\begin{array}{l}\text { diversidade na prática } \\
\text { docente. }\end{array}\end{array}$ \\
\hline
\end{tabular}




\begin{tabular}{|c|c|c|c|c|c|c|c|c|c|c|}
\hline & & & & & & & & $\begin{array}{l}\text { PEDAGÓGI } \\
\text { CAS }\end{array}$ & & \\
\hline E5 & $\begin{array}{c}\text { UFJF } \\
\text { (Universida } \\
\text { de Federal } \\
\text { de Juiz de } \\
\text { Fora) }\end{array}$ & FEDERAL & $\begin{array}{l}\text { CIÊNCIAS } \\
\text { HUMANAS }\end{array}$ & $\begin{array}{l}\text { EDUCAÇ } \\
\tilde{A} O\end{array}$ & $\begin{array}{l}\text { EDUCAÇ } \\
\tilde{A} O(M / D)\end{array}$ & $\begin{array}{l}\text { EDUCAÇÃ } \\
\mathrm{O}\end{array}$ & $\begin{array}{l}\text { EDUCAÇÃO } \\
\text { BRASILEIRA: } \\
\text { GESTÃO E } \\
\text { PRÁTICAS } \\
\text { PEDAGÓGICAS }\end{array}$ & $\begin{array}{l}\text { LINGUAGE } \\
\text { M, } \\
\text { CONHECI } \\
\text { MENTO E } \\
\text { FORMAÇÃ } \\
\text { O DE } \\
\text { PROFESSO } \\
\text { RES }\end{array}$ & $\begin{array}{l}\text { 1999(M) } \\
\text { e } \\
\text { 2008(D) }\end{array}$ & 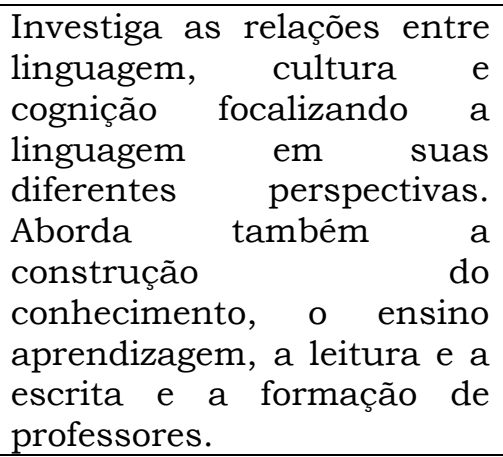 \\
\hline E6 & $\begin{array}{c}\text { UEMS } \\
\text { (Universida } \\
\text { de } \\
\text { Estadual } \\
\text { de Mato } \\
\text { Grosso do } \\
\text { Sul) }\end{array}$ & ESTADUAL & $\begin{array}{l}\text { CIÊNCIAS } \\
\text { HUMANAS }\end{array}$ & $\begin{array}{l}\text { EDUCAÇ } \\
\tilde{A} O\end{array}$ & $\begin{array}{l}\text { EDUCAÇ } \\
\tilde{A} O(F)\end{array}$ & $\begin{array}{l}\text { EDUCAÇÃ } \\
\text { O }\end{array}$ & $\begin{array}{l}\text { EDUCAÇÃO, } \\
\text { LINGUAGEM E } \\
\text { SOCIEDADE }\end{array}$ & $\begin{array}{l}\text { LINGUAGE } \\
\text { M, } \\
\text { LITERATU } \\
\text { RA, } \\
\text { EDUCAÇÃ } \\
\text { O E } \\
\text { SOCIEDAD } \\
\text { E }\end{array}$ & $2011(\mathrm{M})$ & $\begin{array}{l}\text { A Ciência da linguagem é o } \\
\text { objeto de estudo desta } \\
\text { linha, com ênfase nos } \\
\text { estudos literários, do texto } \\
\text { e ensino de linguas, } \\
\text { levando-se em consideração } \\
\text { as práticas sociais, as } \\
\text { diversas modalidades } \\
\text { linguísticas, os diversos } \\
\text { gêneros textuais, entre } \\
\text { outras. }\end{array}$ \\
\hline E7 & $\begin{array}{c}\text { UFMT 1 } \\
\text { (Universida } \\
\text { de Federal } \\
\text { de Mato } \\
\text { Grosso) }\end{array}$ & FEDERAL & $\begin{array}{l}\text { CIÊNCIAS } \\
\text { HUMANAS }\end{array}$ & $\begin{array}{l}\text { EDUCAÇ } \\
\tilde{A} O\end{array}$ & $\begin{array}{l}\text { EDUCAÇ } \\
\tilde{A} O(M)\end{array}$ & $\begin{array}{l}\text { EDUCAÇÃ } \\
\mathrm{O}\end{array}$ & EDUCAÇÃO & $\begin{array}{l}\text { CULTURAS } \\
\text { ESCOLARE } \\
\text { S E } \\
\text { LINGUAGE } \\
\text { NS }\end{array}$ & $\begin{array}{l}2008(\mathrm{M}) \\
\text { e } 2009 \\
\text { (D) }\end{array}$ & $\begin{array}{l}\text { Contempla estudos sobre } \\
\text { Alfabetização, Letramento, } \\
\text { Literatura } \\
\text { Formação do Leitor, EJA, } \\
\text { Corporidade e Ludicidade } \\
\text { no Espaço Escolar, com } \\
\text { influência sobre diversas } \\
\text { dimensões que abrangem } \\
\text { as relações da criança } \\
\text { consigo, com outros e com } \\
\text { o mundo. }\end{array}$ \\
\hline E8 & $\begin{array}{c}\text { UFMT 2 } \\
\text { (Universida } \\
\text { de Federal } \\
\text { de Mato } \\
\text { Grosso) }\end{array}$ & FEDERAL & $\begin{array}{l}\text { CIÊNCIAS } \\
\text { HUMANAS }\end{array}$ & $\begin{array}{l}\text { EDUCAÇ } \\
\tilde{A} \mathrm{O}\end{array}$ & $\begin{array}{l}\text { EDUCAÇ } \\
\tilde{A} O(M / D)\end{array}$ & $\begin{array}{l}\text { EDUCAÇÃ } \\
\text { O }\end{array}$ & $\begin{array}{l}\text { EDUCAÇÃO, } \\
\text { CULTURA E } \\
\text { PROCESSOS } \\
\text { FORMATIVOS }\end{array}$ & $\begin{array}{l}\text { LINGUAGE } \\
\text { NS, } \\
\text { CULTURA } \\
\text { E } \\
\text { CONSTRU } \\
\text { ÇÃO DO } \\
\text { CONHECI }\end{array}$ & $2010(\mathrm{M})$ & 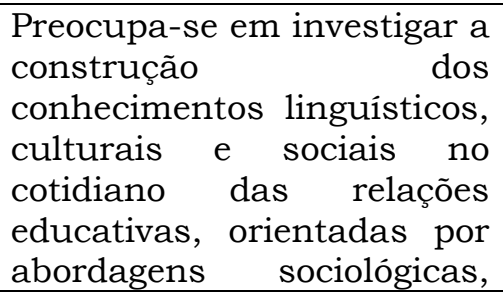 \\
\hline
\end{tabular}




\begin{tabular}{|c|c|c|c|c|c|c|c|c|c|c|}
\hline & & & & & & & & $\begin{array}{l}\text { MENTO: } \\
\text { PERSPECT } \\
\text { IVAS } \\
\text { HISTÓRICA } \\
\text { E } \\
\text { CONTEMP } \\
\text { ORÂNEA } \\
\end{array}$ & & $\begin{array}{l}\text { psicológicas, históricas e } \\
\text { linguísticas. }\end{array}$ \\
\hline E9 & $\begin{array}{c}\text { UFPE } \\
\text { (Universida } \\
\text { de Federal } \\
\text { de } \\
\text { Pernambuc } \\
\text { o) }\end{array}$ & FEDERAL & $\begin{array}{l}\text { CIÊNCIAS } \\
\text { HUMANAS }\end{array}$ & $\begin{array}{l}\text { EDUCAÇ } \\
\tilde{A} O\end{array}$ & $\begin{array}{l}\text { EDUCAÇ } \\
\tilde{A O}(\mathrm{M} / \mathrm{D})\end{array}$ & $\begin{array}{l}\text { PLANEJA } \\
\text { MENTO } \\
\text { EDUCACI } \\
\text { ONAL }\end{array}$ & EDUCAÇÃO & $\begin{array}{l}\text { EDUCAÇÃ } \\
\text { O E } \\
\text { LINGUAGE } \\
\text { M }\end{array}$ & $\begin{array}{l}\text { 1996(M) } \\
\text { e } \\
\text { 2002(D) }\end{array}$ & $\begin{array}{lr}\text { Desenvolve } & \text { pesquisas } \\
\text { acerca de várias temáticas } \\
\text { ligada ao ensino e } \\
\text { aprendizagem da lingua } \\
\text { portuguesa: práticas de } \\
\text { alfabetização e letramento; } \\
\text { formação de professores, } \\
\begin{array}{l}\text { avaliação } \\
\text { propostas educacional; } \\
\text { entre outras. }\end{array} \\
\end{array}$ \\
\hline E10 & $\begin{array}{c}\text { UFF } \\
\text { (Universida } \\
\text { de Federal } \\
\text { Fluminens } \\
\text { e) }\end{array}$ & FEDERAL & $\begin{array}{l}\text { CIÊNCIAS } \\
\text { HUMANAS }\end{array}$ & $\begin{array}{l}\text { EDUCAÇ } \\
\tilde{A} O\end{array}$ & $\begin{array}{l}\text { EDUCAÇ } \\
\tilde{A} O(\mathrm{M} / \mathrm{D})\end{array}$ & $\begin{array}{l}\text { EDUCAÇÃ } \\
\text { O }\end{array}$ & $\begin{array}{l}\text { LINGUAGEM, } \\
\text { SUBJETIVIDAD } \\
\text { E, CULTURA }\end{array}$ & $\begin{array}{l}\text { LINGUAGE } \\
\text { M: } \\
\text { PROCESS } \\
\text { OS DE } \\
\text { PRODUÇÃ } \\
\text { O DE } \\
\text { LINGUAGE } \\
\text { NS, } \\
\text { IDENTIDA } \\
\text { DES } \\
\text { CULTURAI } \\
\text { S E } \\
\text { PRÁTICAS } \\
\text { EDUCATIV } \\
\text { AS }\end{array}$ & $\begin{array}{l}\text { 1994(M) } \\
\text { e } \\
\text { 1995(D) }\end{array}$ & $\begin{array}{l}\text { Tem como eixo central a } \\
\text { linguagem verbal, o estudo } \\
\text { de sua natureza e relações } \\
\text { com a sociedade, a cultura } \\
\text { e a história. Pesquisa } \\
\text { problemas } \\
\text { apropriação da linguagem } \\
\text { oral e escrita; espaços } \\
\text { educativos, politicas } \\
\text { linguísticas, variação e } \\
\text { diversidade. }\end{array}$ \\
\hline E11 & $\begin{array}{c}\text { UNIRIO } \\
\text { (Universida } \\
\text { de Federal } \\
\text { do Estado } \\
\text { do Rio de } \\
\text { Janeiro) }\end{array}$ & FEDERAL & $\begin{array}{l}\text { CIÊNCIAS } \\
\text { HUMANAS }\end{array}$ & $\begin{array}{l}\text { EDUCAÇ } \\
\tilde{A} O\end{array}$ & $\begin{array}{l}\text { EDUCAÇ } \\
\tilde{A} O(M / D)\end{array}$ & $\begin{array}{l}\text { EDUCAÇÃ } \\
\mathrm{O}\end{array}$ & $\begin{array}{l}\text { EDUCAÇÃO, } \\
\text { CULTURA E } \\
\text { LINGUAGENS }\end{array}$ & $\begin{array}{l}\text { PRÁTICAS } \\
\text { EDUCATIV } \\
\text { AS, } \\
\text { LINGUAGE } \\
\text { NS E } \\
\text { TECNOLO } \\
\text { GIA }\end{array}$ & 2003(M) & $\begin{array}{lr}\text { Investigam-se } & \text { práticas } \\
\text { educativas e } & \text { diferentes } \\
\text { formas de } & \text { linguagens } \\
\text { presentes no } & \text { mundo } \\
\text { contemporâneo, } & \text { em } \\
\text { diferentes } & \text { suportes } \\
\text { tecnológicos, considerando } \\
\text { que em todos os espaços } \\
\text { educativos são construídos } \\
\text { conhecimentos e uma }\end{array}$ \\
\hline
\end{tabular}




\begin{tabular}{|c|c|c|c|c|c|c|c|c|c|c|}
\hline & & & & & & & & & & $\begin{array}{l}\text { grande cadeia de } \\
\text { comunicação. }\end{array}$ \\
\hline E12 & $\begin{array}{c}\text { UFRN } \\
\text { (Universida } \\
\text { de Federal } \\
\text { do Rio } \\
\text { Grande do } \\
\text { Norte) }\end{array}$ & FEDERAL & $\begin{array}{l}\text { CIÊNCIAS } \\
\text { HUMANAS }\end{array}$ & $\begin{array}{l}\text { EDUCAÇ } \\
\tilde{A} O\end{array}$ & $\begin{array}{l}\text { EDUCAÇ } \\
\tilde{A O}(\mathrm{M} / \mathrm{D})\end{array}$ & $\begin{array}{l}\text { EDUCAÇÃ } \\
\mathrm{O}\end{array}$ & EDUCAÇÃO & $\begin{array}{l}\text { EDUCAÇ̃̃ } \\
\text { O, } \\
\text { LINGUAGE } \\
\text { M E } \\
\text { FORMAÇÃ } \\
\text { O DO } \\
\text { LEITOR }\end{array}$ & $\begin{array}{l}1978(\mathrm{M}) \\
\mathrm{e} \\
1994(\mathrm{D})\end{array}$ & $\begin{array}{l}\text { Estudos } \\
\text { relacionados }\end{array}$ \\
\hline E13 & $\begin{array}{c}\text { UFPEL } \\
\text { (Universida } \\
\text { de Federal } \\
\text { de Pelotas) }\end{array}$ & FEDERAL & $\begin{array}{l}\text { CIÊNCIAS } \\
\text { HUMANAS }\end{array}$ & $\begin{array}{l}\text { EDUCAÇ } \\
\tilde{A} O\end{array}$ & $\begin{array}{l}\text { EDUCAÇ } \\
\tilde{A O}(\mathrm{M} / \mathrm{D})\end{array}$ & $\begin{array}{l}\text { EDUCAÇÃ } \\
\mathrm{O}\end{array}$ & EDUCAÇÃO & $\begin{array}{l}\text { CULTURA } \\
\text { ESCRITA, } \\
\text { LINGUAGE } \\
\text { NS E } \\
\text { APRENDIZ } \\
\text { AGEM }\end{array}$ & 2000(M) & $\begin{array}{l}\text { A linha de pesquisa } \\
\text { privilegia investigações } \\
\text { sobre os processos de } \\
\text { escolarização, aquisição da } \\
\text { linguagem oral e escrita, as } \\
\text { relações entre escolarização } \\
\text { e linguagem, entre outras. }\end{array}$ \\
\hline E14 & $\begin{array}{c}\text { FURG } \\
\text { (Universida } \\
\text { de Federal } \\
\text { do Rio } \\
\text { Grande) }\end{array}$ & FEDERAL & $\begin{array}{l}\text { CIÊNCIAS } \\
\text { HUMANAS }\end{array}$ & $\begin{array}{l}\text { EDUCAÇ } \\
\tilde{A} O\end{array}$ & $\begin{array}{l}\text { EDUCAÇ } \\
\tilde{A} O(M)\end{array}$ & $\begin{array}{l}\text { EDUCAÇÃ } \\
\text { O }\end{array}$ & EDUCAÇÃO & $\begin{array}{l}\text { CULTURAS } \\
\text { LINGUAGE } \\
\text { NS E } \\
\text { UTOPIAS }\end{array}$ & $2012(\mathrm{M})$ & $\begin{array}{l}\text { Inaugura um campo de } \\
\text { possibilidades de } \\
\text { reinvenção das linguagens, } \\
\text { das culturas e das utopias. } \\
\text { Busca compreenção dos } \\
\text { processos educativos } \\
\text { formais e não formais que } \\
\text { envolvem o fazer docente e } \\
\text { os entornos dos contextos } \\
\text { educacionais. }\end{array}$ \\
\hline E15 & $\begin{array}{c}\text { UFSC } \\
\text { (Universida } \\
\text { de Federal } \\
\text { de Santa } \\
\text { Catarina) }\end{array}$ & FEDERAL & $\begin{array}{l}\text { CIÊNCIAS } \\
\text { HUMANAS }\end{array}$ & $\begin{array}{l}\text { EDUCAÇ } \\
\tilde{A} O\end{array}$ & $\begin{array}{l}\text { EDUCAÇ } \\
\tilde{A} O(M / D)\end{array}$ & $\begin{array}{l}\text { EDUCAÇÃ } \\
\text { O }\end{array}$ & EDUCAÇÃO & $\begin{array}{l}\text { EDUCAÇÃ } \\
\text { O E } \\
\text { COMUNIC } \\
\text { AÇÃO }\end{array}$ & $\begin{array}{l}\text { 1984(M) } \\
\mathrm{e} \\
\text { 1994(D) }\end{array}$ & 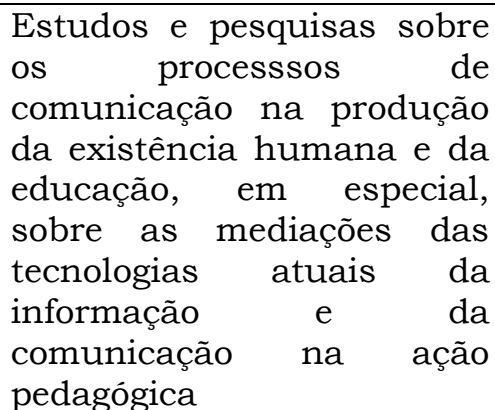 \\
\hline
\end{tabular}




\begin{tabular}{|c|c|c|c|c|c|c|c|c|c|c|}
\hline E16 & $\begin{array}{c}\text { UDESC } \\
\text { (Universida } \\
\text { de } \\
\text { Estadual } \\
\text { de Santa } \\
\text { Catarina) }\end{array}$ & ESTADUAL & $\begin{array}{l}\text { CIÊNCIAS } \\
\text { HUMANAS }\end{array}$ & $\begin{array}{l}\text { EDUCAÇ } \\
\tilde{A} O\end{array}$ & $\begin{array}{l}\text { EDUCAÇ } \\
\tilde{A} O(M / D)\end{array}$ & $\begin{array}{l}\text { EDUCAÇÃ } \\
\mathrm{O}\end{array}$ & EDUCAÇÃO & $\begin{array}{l}\text { EDUCAÇÃ } \\
\text { O, } \\
\text { COMUNIC } \\
\text { AÇÃO E } \\
\text { TECNOLO } \\
\text { GIA }\end{array}$ & $\begin{array}{l}\text { 2007(M) } \\
\text { e } \\
2012(\mathrm{D})\end{array}$ & $\begin{array}{l}\text { Investiga as interfaces entre } \\
\text { educação, comunicação e } \\
\text { tecnologia, com ênfase no } \\
\text { estudo, desenvolvimento e } \\
\text { avaliação de propostas } \\
\text { pedagógicas desenvolvidas } \\
\text { em cenários de educação } \\
\text { formal, nano-formal, } \\
\text { presencial, a distância, } \\
\text { inicial e contínua. }\end{array}$ \\
\hline E17 & $\begin{array}{c}\text { FURB } \\
\text { (Universida } \\
\text { de } \\
\text { Regional } \\
\text { de } \\
\text { Blumenal) }\end{array}$ & $\begin{array}{l}\text { MUNICIPA } \\
\text { L }\end{array}$ & $\begin{array}{l}\text { CIÊNCIAS } \\
\text { HUMANAS }\end{array}$ & $\begin{array}{l}\text { EDUCAÇ } \\
\tilde{A} O\end{array}$ & $\begin{array}{l}\text { EDUCAÇ } \\
\tilde{A} O(M)\end{array}$ & $\begin{array}{l}\text { EDUCAÇÃ } \\
\mathrm{O}\end{array}$ & EDUCAÇÃO & $\begin{array}{l}\text { LINGUAGE } \\
\text { M E } \\
\text { EDUCAÇÃ } \\
\text { O }\end{array}$ & 2001(M) & $\begin{array}{l}\text { Aspectos cognitivos, sociais } \\
\text { e históricos das práticas de } \\
\text { linguagem. Cultura escrita. } \\
\text { Alfabetização e letramento. } \\
\text { Práticas de letramento em } \\
\text { contexto de formação de } \\
\text { professores. Letramento } \\
\text { acadêmico. Práticas de } \\
\text { letramento relacionadas à } \\
\text { lingua materna... }\end{array}$ \\
\hline E18 & $\begin{array}{c}\text { USP } \\
\text { (Universida } \\
\text { de de São } \\
\text { Paulo) }\end{array}$ & ESTADUAL & $\begin{array}{l}\text { CIÊNCIAS } \\
\text { HUMANAS }\end{array}$ & $\begin{array}{l}\text { EDUCAÇ } \\
\tilde{A} O\end{array}$ & $\begin{array}{l}\text { EDUCAÇ } \\
\tilde{A O}(\mathrm{M} / \mathrm{D})\end{array}$ & $\begin{array}{l}\text { EDUCAÇÃ } \\
\mathrm{O}\end{array}$ & EDUCAÇÃO & $\begin{array}{l}\text { LINGUAGE } \\
\text { M E } \\
\text { EDUCAÇÃ } \\
\text { O }\end{array}$ & $\begin{array}{l}\text { 1997(M e } \\
\mathrm{D})\end{array}$ & $\begin{array}{l}\text { Desenvolve estudos de } \\
\text { linguagem e de literatura, } \\
\text { focalizando questões de } \\
\text { ensino e de aprendizagem, } \\
\text { bem como estudos } \\
\text { referentes à arte e à } \\
\text { comunicação em suas } \\
\text { múltiplas relações com a } \\
\text { escola. }\end{array}$ \\
\hline E19 & $\begin{array}{c}\text { UNESP/MA } \\
\text { R } \\
\text { (Universida } \\
\text { de } \\
\text { Estadual } \\
\text { Paulista } \\
\text { Júlio de } \\
\text { Mesquita } \\
\text { Filho/Maril } \\
\text { ia) } \\
\end{array}$ & ESTADUAL & $\begin{array}{l}\text { CIÊNCIAS } \\
\text { HUMANAS }\end{array}$ & $\begin{array}{l}\text { EDUCAÇ } \\
\tilde{A} O\end{array}$ & $\begin{array}{l}\text { EDUCAÇ } \\
\tilde{A} O \text { (M/D) }\end{array}$ & $\begin{array}{l}\text { ENSINO- } \\
\text { APRENDIZ } \\
\text { AGEM }\end{array}$ & $\begin{array}{l}\text { ENSINO NA } \\
\text { EDUCACAO } \\
\text { BRASILEIRA }\end{array}$ & $\begin{array}{l}\text { ABORDAG } \\
\text { ENS } \\
\text { PEDAGÓGI } \\
\text { CAS DO } \\
\text { ENSINO } \\
\text { DE } \\
\text { LINGUAGE } \\
\text { M }\end{array}$ & $\begin{array}{l}\text { 1988(M) } \\
\text { e } \\
1993(\mathrm{D})\end{array}$ & $\begin{array}{l}\text { Conceitos e prát. de leitura. } \\
\text { Proc. de letramento. Leitura } \\
\text { e repr. sociais. A prod. } \\
\text { textual escrita nas sér. } \\
\text { iniciais do E. F. Estr. de } \\
\text { comunicação. Inserção dos } \\
\text { meios de com. na escola } \\
\text { bras. A ed. de crianças de } 0 \\
\text { a } 10 \text { anos na perspect. hist. } \\
\text { cultural. }\end{array}$ \\
\hline E20 & $\begin{array}{c}\text { UFV } \\
\text { (Universida } \\
\text { de Federal }\end{array}$ & FEDERAL & $\begin{array}{l}\text { LINGUÍSTI } \\
\text { CA, } \\
\text { LETRAS E }\end{array}$ & LETRAS & $\begin{array}{l}\text { LETRAS } \\
\text { (M) }\end{array}$ & LETRAS & $\begin{array}{l}\text { ESTUDOS } \\
\text { LINGUÍSTICOS }\end{array}$ & $\begin{array}{l}\text { LINGUÍSTI } \\
\text { CA } \\
\text { APLICADA: }\end{array}$ & 2009(M) & $\begin{array}{l}\text { Estudo de questões teóricas } \\
\text { e empiricas sobre o ensino } \\
\text { e aprendizagem de lingua }\end{array}$ \\
\hline
\end{tabular}




\begin{tabular}{|c|c|c|c|c|c|c|c|c|c|c|}
\hline & de Viçosa) & & ARTES & & & & & $\begin{array}{l}\text { ENSINO E } \\
\text { APRENDIZ } \\
\text { AGEM DE } \\
\text { LÍNGUA } \\
\text { MATERNA } \\
\text { E } \\
\text { ESTRANGE } \\
\text { IRA } \\
\end{array}$ & & $\begin{array}{l}\text { materna e estrangeira } \\
\text { dentro de uma perspectiva } \\
\text { discursiva e sócio-cultural } \\
\text { com foco em: formação de } \\
\text { professores, } \\
\text { crenças/representações } \\
\text { sociais de professores e } \\
\text { alunos. }\end{array}$ \\
\hline E21 & $\begin{array}{c}\text { UEMS } \\
\text { (Universida } \\
\text { de } \\
\text { Estadual } \\
\text { do Mato } \\
\text { Grosso do } \\
\text { Sul) }\end{array}$ & ESTADUAL & $\begin{array}{l}\text { LINGUÍSTI } \\
\text { CA, } \\
\text { LETRAS E } \\
\text { ARTES }\end{array}$ & LETRAS & $\begin{array}{l}\text { LETRAS } \\
\text { (M) }\end{array}$ & LETRAS & $\begin{array}{l}\text { LINGUAGEM: } \\
\text { LÍNGUA E } \\
\text { LITERATURA }\end{array}$ & $\begin{array}{l}\text { ENSINO } \\
\text { DE } \\
\text { LINGUAGE } \\
\text { NS }\end{array}$ & $2011(\mathrm{M})$ & $\begin{array}{l}\text { Promover a discussão de } \\
\text { questões relacionadas ao } \\
\text { ensino de Lingua e e } \\
\text { literatura articuladas com } \\
\text { as diferentes formas de } \\
\text { linguagens. A ideia central } \\
\text { é propiciar mecanismos de } \\
\text { reflexão sobre as práticas } \\
\text { de ensino de linguagens. }\end{array}$ \\
\hline E22 & $\begin{array}{c}\text { UFPE } \\
\text { (Universida } \\
\text { de Federal } \\
\text { de } \\
\text { Pernambuc } \\
\text { o) }\end{array}$ & FEDERAL & $\begin{array}{l}\text { LINGUÍSTI } \\
\text { CA, } \\
\text { LETRAS E } \\
\text { ARTES }\end{array}$ & LETRAS & $\begin{array}{l}\text { LETRAS } \\
(\mathrm{M} / \mathrm{D})\end{array}$ & LETRAS & LINGUÍSTICA & $\begin{array}{l}\text { ANÁLISE } \\
\text { DE } \\
\text { PRÁTICAS } \\
\text { DE } \\
\text { LINGUAGE } \\
\text { M NO } \\
\text { CAMPO DO } \\
\text { ENSINO } \\
\end{array}$ & $\begin{array}{l}\text { 1976(M)e } \\
\text { 1990(D) }\end{array}$ & $\begin{array}{l}\text { investigações, em diferentes } \\
\text { perspectivas } \\
\text { relacionadas a:formação de } \\
\text { professores, } \\
\text { avaliativas, práticas } \\
\text { didático, entre outros }\end{array}$ \\
\hline E23 & $\begin{array}{c}\text { UEM } \\
\text { (Universida } \\
\text { de } \\
\text { Estadual } \\
\text { de } \\
\text { Maringá) } \\
\end{array}$ & ESTADUAL & $\begin{array}{l}\text { LINGUÍSTI } \\
\text { CA, } \\
\text { LETRAS E } \\
\text { ARTES }\end{array}$ & LETRAS & $\begin{array}{l}\text { LETRAS } \\
\text { (M/D) }\end{array}$ & LETRAS & $\begin{array}{l}\text { ESTUDOS } \\
\text { LINGÜÍSTICOS }\end{array}$ & $\begin{array}{l}\text { ENSINO- } \\
\text { APRENDIZ } \\
\text { AGEM DE } \\
\text { LÍNGUAS }\end{array}$ & $\begin{array}{l}\text { 2004(M) } \\
\text { e } \\
2011(D)\end{array}$ & $\begin{array}{l}\text { Objetiva-se a realização de } \\
\text { pesquisas que enfoquem } \\
\text { aspectos de ensino e } \\
\text { aprendizagem de linguas. }\end{array}$ \\
\hline E24 & $\begin{array}{c}\text { UERJ } \\
\text { (Universida } \\
\text { de } \\
\text { Estadual } \\
\text { do Rio de } \\
\text { Janeiro) }\end{array}$ & ESTADUAL & $\begin{array}{l}\text { LINGUÍSTI } \\
\text { CA, } \\
\text { LETRAS E } \\
\text { ARTES }\end{array}$ & LETRAS & $\begin{array}{l}\text { LETRAS } \\
\text { (M/D) }\end{array}$ & $\begin{array}{l}\text { LITERATU } \\
\text { RA } \\
\text { BRASILEI } \\
\text { RA }\end{array}$ & $\begin{array}{l}\text { LÍNGUA } \\
\text { PORTUGUESA }\end{array}$ & $\begin{array}{l}\text { ENSINO } \\
\text { DA } \\
\text { LÍNGUA } \\
\text { PORTUGU } \\
\text { ESA: } \\
\text { HISTÓRIA, } \\
\text { POLÍTICAS } \\
\text {, SENTIDO } \\
\text { SOCIAL, } \\
\text { METODOL } \\
\text { OGIAS E }\end{array}$ & $\begin{array}{l}\text { 1993(M) } \\
\text { e } \\
\text { 2002(D) }\end{array}$ & $\begin{array}{l}\text { Abordagem dos principais } \\
\text { problemas referentes ao } \\
\text { ensino da LP, tendo em } \\
\text { vista sua complexidade e } \\
\text { dimensão: } \\
\text { gramaticais e lingüísticos, } \\
\text { perspectivas estilísticas e } \\
\text { semióticas, bem como as } \\
\text { questões de leitura, livro } \\
\text { didático e produção de } \\
\text { textos. }\end{array}$ \\
\hline
\end{tabular}




\begin{tabular}{|c|c|c|c|c|c|c|c|c|c|c|}
\hline & & & & & & & & PESQUISA & & \\
\hline E25 & $\begin{array}{c}\text { UFPEL } \\
\text { (Universida } \\
\text { de Federal } \\
\text { de Pelotas) }\end{array}$ & FEDERAL & $\begin{array}{l}\text { LINGUÍSTI } \\
\text { CA, } \\
\text { LETRAS E } \\
\text { ARTES }\end{array}$ & LETRAS & $\begin{array}{l}\text { LETRAS } \\
\text { (M) }\end{array}$ & LETRAS & $\begin{array}{l}\text { ESTUDOS DA } \\
\text { LINGUAGEM }\end{array}$ & $\begin{array}{l}\text { ENSINO E } \\
\text { APRENDIZ } \\
\text { AGEM DE } \\
\text { LÍNGUAS }\end{array}$ & 2011(M) & $\begin{array}{l}\text { Com base em estudos de } \\
\text { Linguistica Aplicada, esta } \\
\text { linha de pesquisa pretende } \\
\text { reunir e estimular projetos } \\
\text { voltados para processos de } \\
\text { ensino e aprendizagem de } \\
\text { linguas materna } \\
\text { estrangeiras. }\end{array}$ \\
\hline E26 & $\begin{array}{c}\text { FUFSE } \\
\text { (Fundação } \\
\text { Universida } \\
\text { de Federal } \\
\text { de Sergipe) }\end{array}$ & FEDERAL & $\begin{array}{l}\text { LINGUÍSTI } \\
\text { CA, } \\
\text { LETRAS E } \\
\text { ARTES }\end{array}$ & LETRAS & $\begin{array}{l}\text { LETRAS } \\
\text { (M) }\end{array}$ & LETRAS & $\begin{array}{l}\text { ESTUDOS } \\
\text { LINGUÍSTICOS }\end{array}$ & $\begin{array}{l}\text { ENSINO } \\
\text { DE } \\
\text { LÍNGUAS E } \\
\text { LITERATU } \\
\text { RAS }\end{array}$ & $2012(\mathrm{M})$ & $\begin{array}{l}\text { Estudos sobre o ensino- } \\
\text { aprendizagem de linguas e } \\
\text { de suas respectivas } \\
\text { literaturas. }\end{array}$ \\
\hline E27 & $\begin{array}{c}\text { UFCG } \\
\text { (Universida } \\
\text { de Federal } \\
\text { de } \\
\text { Campina } \\
\text { Grande) }\end{array}$ & FEDERAL & $\begin{array}{l}\text { LINGUÍSTI } \\
\text { CA, } \\
\text { LETRAS E } \\
\text { ARTES }\end{array}$ & LETRAS & $\begin{array}{l}\text { LINGUAG } \\
\text { EM E } \\
\text { ENSINO } \\
\text { (M) }\end{array}$ & LETRAS & $\begin{array}{l}\text { ENSINO- } \\
\text { APRENDIZAGE } \\
\text { M DE LINGUA E } \\
\text { LITERATURA }\end{array}$ & $\begin{array}{l}\text { LÍNGUA E } \\
\text { INTERAÇÃ } \\
\text { O EM } \\
\text { CONTEXT } \\
\text { O DE } \\
\text { ENSINO }\end{array}$ & 2004(M) & $\begin{array}{l}\text { Linha de reflexão com dois } \\
\text { eixos temáticos: } 1 . \\
\text { lingua(gem) no contexto das } \\
\text { práticas } \\
\text { contemporâneas; sociais } \\
\text { formação de professor, } \\
\text { focando a construção de } \\
\text { saberes e de objeto de } \\
\text { ensino. }\end{array}$ \\
\hline E28 & $\begin{array}{c}\text { UFRJ } \\
\text { (Universida } \\
\text { de Federal } \\
\text { do Rio de } \\
\text { Janeiro) }\end{array}$ & FEDERAL & $\begin{array}{l}\text { LINGUÍSTI } \\
\text { CA, } \\
\text { LETRAS E } \\
\text { ARTES }\end{array}$ & LETRAS & $\begin{array}{l}\text { LETRAS - } \\
\text { LETRAS } \\
\text { VERNÁC } \\
\text { ULAS } \\
\text { (M/D) }\end{array}$ & LETRAS & $\begin{array}{l}\text { ENSINO- } \\
\text { APRENDIZAGE } \\
\text { M DE LINGUA E } \\
\text { LITERATURA }\end{array}$ & $\begin{array}{l}\text { LÍNGUA(G } \\
\text { EM) EM } \\
\text { CONTEXT } \\
\text { O DE } \\
\text { ENSINO } \\
\text { DE } \\
\text { PORTUGU } \\
\text { ES - } \\
\text { LÍNGUA } \\
\text { MATERNA }\end{array}$ & $\begin{array}{l}1970 \\
\text { (MeD) }\end{array}$ & $\begin{array}{l}\text { Estuda a lingua(gem), } \\
\text { focalizando a natureza e/ou } \\
\text { a descrição do fato } \\
\text { 129inguistico/discursivo no } \\
\text { contexto das práticas } \\
\text { sociais e o o trabalho } \\
\text { docente, focalizando a } \\
\text { formação e a prática do } \\
\text { professor e a construção de } \\
\text { objeto(s) de ensino e de } \\
\text { identidades. }\end{array}$ \\
\hline E29 & $\begin{array}{c}\text { UFAL } \\
\text { (Universida } \\
\text { de Federal } \\
\text { de Alagoas) }\end{array}$ & FEDERAL & $\begin{array}{l}\text { LINGUÍSTI } \\
\text { CA, } \\
\text { LETRAS E } \\
\text { ARTES }\end{array}$ & LETRAS & $\begin{array}{l}\text { LETRAS } \\
\text { E } \\
\text { LINGUÍS } \\
\text { TICA } \\
\text { (M/D) }\end{array}$ & LETRAS & $\begin{array}{l}\text { LINGUA } \\
\text { PORTUGUESA }\end{array}$ & $\begin{array}{l}\text { LINGUA E } \\
\text { ENSINO }\end{array}$ & ? & $\begin{array}{l}\text { Exame das normas e } \\
\text { registros que caracterizam o } \\
\text { português nos niveis } \\
\text { semântico-lexical, fonético- } \\
\text { fonol[ogico, morfossintático } \\
\text { e textual, com vista ao seu } \\
\text { ensino como língua } 1 \text { e }\end{array}$ \\
\hline
\end{tabular}




\begin{tabular}{|c|c|c|c|c|c|c|c|c|c|c|}
\hline & & & & & & & & & & língua 2. \\
\hline E30 & $\begin{array}{c}\text { UECE } \\
\text { (Universida } \\
\text { de } \\
\text { Estadual } \\
\text { do Ceará) }\end{array}$ & ESTADUAL & $\begin{array}{l}\text { LINGUÍSTI } \\
\text { CA, } \\
\text { LETRAS E } \\
\text { ARTES }\end{array}$ & LETRAS & $\begin{array}{l}\text { LINGUÍS } \\
\text { TICA } \\
\text { APLICAD } \\
\text { A (M/D) }\end{array}$ & LETRAS & $\begin{array}{l}\text { LINGUAGEM E } \\
\text { INTERAÇÃO }\end{array}$ & $\begin{array}{l}\text { LINGUAGE } \\
\text { M, } \\
\text { TECNOLO } \\
\text { GIA E } \\
\text { ENSINO }\end{array}$ & $\begin{array}{l}\text { 1998(M) } \\
\text { e } \\
2012(\mathrm{D})\end{array}$ & $\begin{array}{l}\text { Estudos sobre } \\
\text { multiletramentos e ensino } \\
\text { de linguas, abordando } \\
\text { gêneros impressos } \\
\text { digitais; o texto em } \\
\text { diferentes perspectivas, } \\
\text { contextos, modalidades } \\
\text { mídias; o trabalho docente } \\
\text { e os recursos instrucionais. }\end{array}$ \\
\hline E31 & $\begin{array}{c}\text { UFS } \\
\text { (Universida } \\
\text { de Federal } \\
\text { de Sergipe) }\end{array}$ & FEDERAL & $\begin{array}{l}\text { LINGUÍSTI } \\
\text { CA, } \\
\text { LETRAS E } \\
\text { ARTES }\end{array}$ & LETRAS & \begin{tabular}{|l} 
LETRAS \\
\end{tabular} & LETRAS & $\begin{array}{l}\text { ENSINO DE } \\
\text { LINGUAS E } \\
\text { LITERATURAS }\end{array}$ & $\begin{array}{l}\text { LINGUAGE } \\
\text { M E } \\
\text { ENSINO }\end{array}$ & & $\begin{array}{l}\text { Abrange uma } \\
\text { multiplicidade de aspectos } \\
\text { dos estudos lingüisticos } \\
\text { literários voltados ao } \\
\text { Ensino-aprendizagem do } \\
\text { Português como lingua } \\
\text { materna e como lingua } \\
\text { estrangeira (PLE). Seu } \\
\text { principal objetivo é formar } \\
\text { profissionais capazes de } \\
\text { lidar com as linguagens, de } \\
\text { forma critica, reflexiva } \\
\text { ética, no âmbito do Ensino } \\
\text { e da pesquisa, conscientes } \\
\text { de sua inserção na na } \\
\text { sociedade. }\end{array}$ \\
\hline
\end{tabular}

